\title{
Regulatory Standards and \\ Other Guidelines for \\ Groundwater Monitoring \\ Programs
}
J. F. Keller
A. J. Schmidt
K. B. Selby

July 1989

Prepared for the U.S. Department of Energy under Contract DE-AC06-76RLO 1830

Pacific Northwest Laboratory

Operated for the U.S. Department of Energy

by Battelle Memorial Institute 


\title{
DISCLAIMER
}

This program was prepared as an account of work sponsored by an agency of the United States Government. Neither the United States Government nor any agency thereof, nor Battelle Memorial Institute, nor any of their employees, makes any warranty, express or implied, or assumes any legal labil ity or responsibility for the accuracy, completeness, or usefulness of any information, apparatus, product, or process disclosed, or represents that it: use would not infringe privately owned rights. Reference herein to any specific commerical product, process, or service by trade name, trademark, manufacturer, or otherwise, does not necessarily constitute or imply its endorsement, recommendation, or favoring by the United States Government or any agency thereof, or Battelle Memorial institute. The views and opinions of authors expressed herein do not necessarily state or reflect those of the United States Government or any agency thereof.

\section{PACIFIC NORTHWEST LABORATORY operated by \\ BATTELLE MEMORIAL INSTITUTE for the \\ UNITED STATES DEPARTMENT OF ENERGY under Contract DE-ACO6-76RLO 1830}

\author{
Printed in the United States of America \\ Available irom \\ National Technical Information Service \\ United States Department of Commerce \\ 52AS Port Royal Road \\ Springfield, Virginia 22161 \\ NTIS Price Codes \\ Microfiche A01 \\ Printed Copy
}

$\begin{array}{cc}\text { Pages } & \begin{array}{c}\text { Price } \\ \text { Codes } \\ 001-025\end{array} \\ 026-050 & \text { A02 } \\ 051-075 & \text { A03 } \\ 076-100 & \text { A04 } \\ 101-125 & \text { AOS } \\ 126-150 & \text { A06 } \\ 151-175 & \text { A07 } \\ 176-200 & \text { A06 } \\ 201-225 & \text { A09 } \\ 226-250 & \text { A10 } \\ 251-275 & \text { A11 } \\ 276-300 & \text { A12 } \\ & \text { A13 }\end{array}$




\section{REGULATORY STANDARDS AND OTHER GUIDELINES FOR GROUNDWATER MONITORING PROGRAMS}
J. F. Keller
A. J. Schmidt
K. B. Selby

July 1989

Prepared for the U.S. Department of Energy under Contract DE-AC06-76RLO I830

Pacific Northwest Laboratory Richland, Washington 99352 


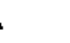




\section{EXECUTIVE SUMMARY}

This report has been prepared to provide information on regulatory programs relevant to a groundwater monitoring program. The information provides a framework within which planners and decision makers can systematically consider the maze of specific requirements and guidance as they develop a groundwater protection strategy for the Hanford Site. Although this report discusses legislation and regulations as they pertain to groundwater monitoring activities, it is not intended as a legal opinion. Rather, it is provided as a guide to the relationships among the various regulatory programs related to groundwater. The report was prepared by Pacific Northwest Laboratory (PNL) for the U.S. Department of Energy (DOE).

Federal and state environmental pollution control statutes and regulations that have been reviewed in this document include the Resource Conservation and Recovery Act (RCRA); Washington's Hazardous Waste Management Act; Washington's Solid Waste Management Act; the Comprehensive Environmental Response, Liability, and Compensation Act (CERCLA); the Superfund Amendments and Reauthorization Act (SARA); the Safe Drinking Water Act (SDWA); and the Clean Water Act (CWA).

The implications and details of these regulations as they may apply to Hanford are discussed. The information contained within this report can be used to develop the Hanford Site's groundwater quality protection programs, assess regulatory compliance, and characterize the Hanford Site for potential remediation and corrective actions.

The Hanford Site is currently operating under a RCRA Part A permit and is, therefore, subject to interim status standards. However, Part B permit applications and/or closure plans for a number of specific waste management units on the Hanford Site are expected to be submitted to the Washington State Department of Ecology (WDOE) and to the U.S. Environmental Protection Agency (EPA) during FY 1989. Consequently, the development of a

comprehensive groundwater protection strategy requires knowledge of both permitted (40 CFR 264) and interim (40 CFR 265) facility standards. 
By understanding the requirements under this suite of statutes, the ability of the Hanford Site to work with regulators, interested parties, and the public will increase. An enhanced understanding of these requirements will also heip technicai staff and managers integrate these requirements into the sitewide monitoring program and ensure that the potential impacts of DOE activities to the Hanford Site groundwater are fully considered. 


\section{ACRONYMS AND ABBREVIATIONS}

$\mathrm{ACL}$

AEA

ARAR

CERCLA

CFR

CWA

DSHS

DOE

DW

DWPL

EHW

EMPP

EPA

EPCRA

FR

HWM

HRS

HSWA

HWCA

HWMA

LLRW

LLRWPA

$\mathrm{MCL}$

MCLG a) ternate contaminant limit

Atomic Energy Act of 1954, as amended

applicable or relevant and appropriate requirements

Comprehensive Environmental Response, Compensation, and Liability Act

Code of Federal Regulations

Clean Water Act (federal)

(Washington State) Department of Social and Health Services

U.S. Department of Energy

dangerous waste

drinking water priority list

extremely hazardous waste

Environmental Management Program Plan

U.S. Environmental Protection Agency

Emergency Planning and Community Right-To-Know Act

Federal Register

hazardous waste management

Hazard Ranking System

Hazardous and Solid Waste Act

Hazardous Waste Cleanup Act

Hazardous Waste Management Act

low-level radioactive waste

Low-Level Radioactive Waste Policy Act of 1985

maximum contaminant level

maximum contaminant level goal 


\begin{tabular}{|c|c|}
\hline NEPA & National Environmental Policy Act \\
\hline NPDES & National Pollutant Discharge Elimination System \\
\hline NPDWR & National Primary Drinking Water Regulations \\
\hline NPL & National Priorities List \\
\hline NWPA & Nuclear Waste Policy Act \\
\hline $0 \& M$ & operation and maintenance \\
\hline $\mathrm{PA} / \mathrm{SI}$ & preliminary assessment/site inspection \\
\hline PNL & Pacific Northwest Laboratory \\
\hline RCRA & Resource Conservation and Recovery Act \\
\hline $\mathrm{RCW}$ & Revised Code of Washington \\
\hline $\mathrm{RD} / \mathrm{RA}$ & remedial design/remedial action \\
\hline $\mathrm{RI} / \mathrm{FS}$ & remedial investigation/feasibility study \\
\hline ROD & record of decision \\
\hline RPM & remedial project manager \\
\hline $\mathrm{RQ}$ & reportable quantity \\
\hline SARA & Superfund Amendments and Reauthorization Act \\
\hline SDWA & Safe Drinking Water Act \\
\hline SMCL & secondary maximum contaminant level \\
\hline SWMA & Solid Waste Management Act \\
\hline TSD & treatment, storage and disposal \\
\hline TPQ & threshold planning quantity \\
\hline TSCA & Toxic Substances Control Act \\
\hline UIC & underground injection control \\
\hline USC & U.S. Code \\
\hline USDW & underground source of drinking water \\
\hline WAC & Washington Administrative Code \\
\hline
\end{tabular}


Washington Department of Ecology

WSR Washington State Register 


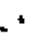




\section{CONTENTS}

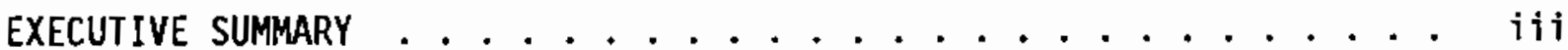

ACRONYMS AND ABBREVIATIONS ................ v

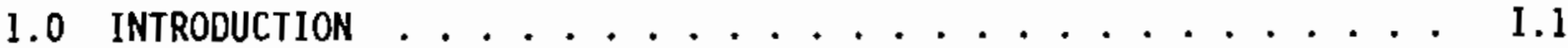

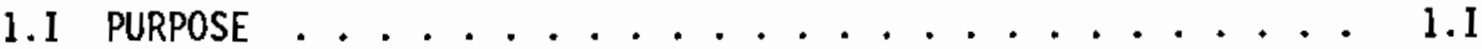

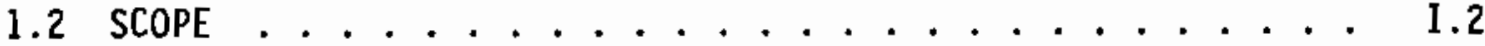

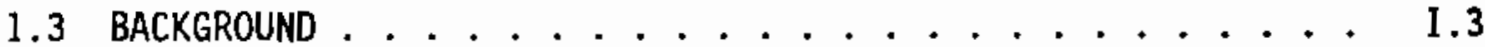

1.4 REPORT OUTLINE . . . . . . . . . . . . . . . 1.3

2.0 REGULATORY REQUIREMENTS FOR HAZARDOUS WASTE MANAGEMENT

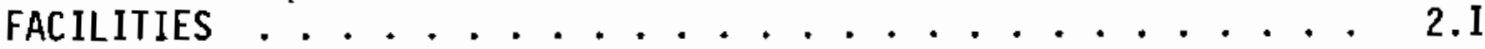

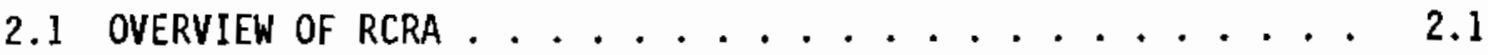

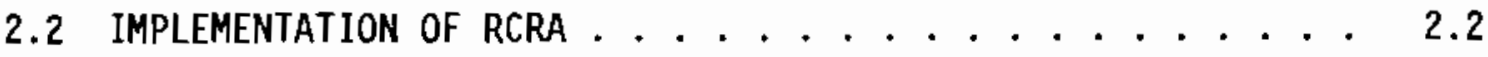

2.3 REGULATORY REQUIREMENTS FOR INTERIM STATUS, CLOSURE,
AND POSTCLOSURE . . . . . . . . . . . . . . . . . .

2.3.1 Applicability of Interim Status . . . . . . 2.5

2.3.2 Groundwater Monitoring Waivers or Exemptions

for Interim Status ............ . . 2.5

2.3.3 Groundwater Monitoring System Requirements . . . . 2.6

2.3.4 Alternate Groundwater Monitoring System . . . . 2.7

2.3.5 Background Monitoring Requirements . . . . . . 2.8

2.3.6 Indicator Evaluation Program ......... 2.10

2.3.7 Groundwater Quality Assessment Program ..... 2. 2.10

2.3.8 Recordkeeping and Reporting .......... 2.12

2.3.9 Chosure and Postclosure Care ......... 2.13

2.4 REGULATORY REQUIREMENTS FOR PERMITTED FACILITIES . . . . . 2.14

2.4.I Applicability................ 2.15 
2.4 .2 Waivers................ 2.15

2.4.3 Groundwater Protection Standard ......... 2.17

2.4 .4 Point of Compliance . . . . . . . . . 2.20

2.4.5 Compliance Period . . . . . . . . . . 2.20

2.4.6 General Groundwater Monitoring Requirements ..... 2.20

2.4.7 Background Monitoring . . . . . . . . . . 2.21

2.4.8 Detection Monitoring Program ........ 2.23

2.4.9 Compliance Monitoring Program ........ 2.26

2.4.10 Corrective Action Program . . . . . . . . 2.29

2.4.11 Recordkeeping and Reporting .......... 2.31

2.4.12 Final Facility Permit - Groundwater Monitoring Requirements ................... 2.34

2.4.13 Closure and Postclosure Care ......... 2.37

2.5 RECENT REgULATORY CHANGES . . . . . . . . . 2.37

2.5.I Final Rules................ 2.37

2.5.2 Final Rule for Groundwater Monitoring
Requirements . . . . . . . . . 2.38

2.5.3 Final Changes to General Groundwater
Monjtoring Requirements .......... 2.38

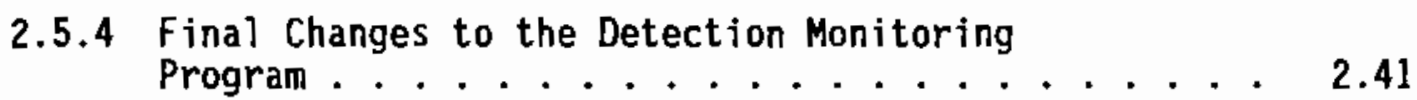

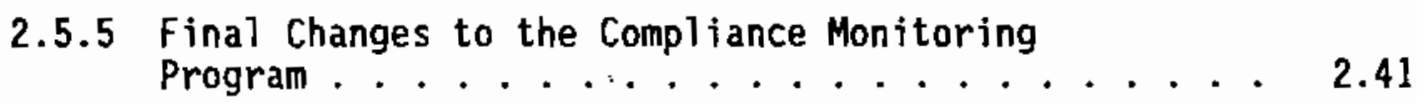

2.5.6 Proposed Rule for Permit Modification for
Hazardous Waste Management Facilities . . . . 2.42

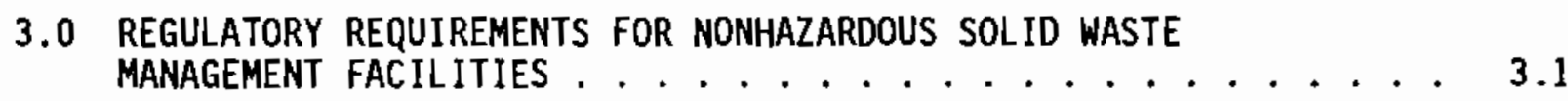

3.1 APPLICABILITY . . . . . . . . . . . . 3.1

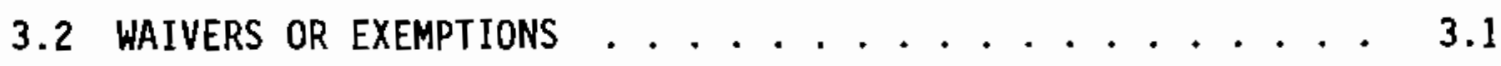


3.3 GENERAL REGULATORY REQUIREMENTS RELATING TO GROUNDWATER

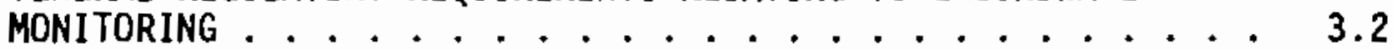

3.4 SAMPLE CONSTITUENTS . . . . . . . . . . . . . 3.4

3.5 REPORTING . . . . . . . . . . . . . . . 3.5

4.0 COMPREHENSIVE ENVIRONMENTAL RESPONSE, COMPENSATION, AND LIABILITY ACT AS AMENDED BY SUPERFUND AMENDMENTS AND REAUTHORIZATION ACT OF 1986 AND THE EMERGENCY PLANNING AND COMMUNITY RIGHT-TO-KNOW ACT OF $1986 \ldots \ldots . \ldots . \ldots . . \ldots . . . \ldots 4$

$4 . I$ INACTIVE WASTE SITES . . . . . . . . . . 4.2

4.1.1 Removal Action ............. 4.2

4.I.2 Remedial Action.............. 4.2

5.0 SAFE ORINKING WATER ACT ..................... 5.1

5.1 PUBLIC WATER SYSTEMS . . . . . . . . . . 5.2

5.1.1 Public Water System Classifications . . . . . . 5.3

5.1.2 Primary and Secondary Drinking Water Standards . . 5.4

5.1.3 Bacteriological Content . . . . . . . . 5.6

5.1.4 Inorganic Chemical and Physical Contaminants . . . 5.8

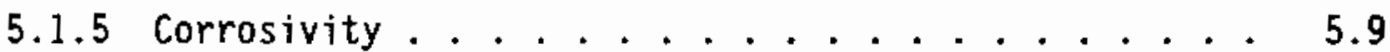

5.1 .6 Pesticides . . . . . . . . . . . . 5.9

5.1 .7 Trihatomethanes .............. 5.9

5.1.8 Standards for Other Organics ......... 5.10

5.1 .9 Radionuclides............. . . 5.10

5.2 UNDERGROUND INJECTION CONTROL PROGRAM . . . . . . . . 5.11

5.2.1 Injection Well Classification......... 5.11

5.2.2 Exemptions for Underground Injection Control Wells ................ 5.14

5.3 ENVIRONMENTAL PROTECTION AGENCY GUIDELINES FOR GROUND-

WATER CLASSIFICATION .................... 5.15 


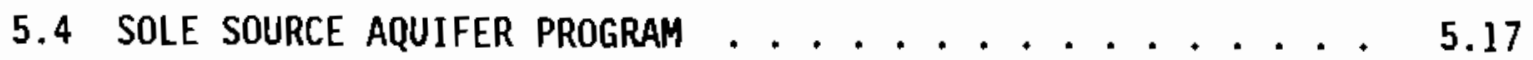

5.5 WELLHEAD PROTECTION AREA PROGRAM . . . . . . . . . . 5.17

6.0 FEDERAL AND STATE CLEAN WATER ACTS . . . . . . . . . 6.1

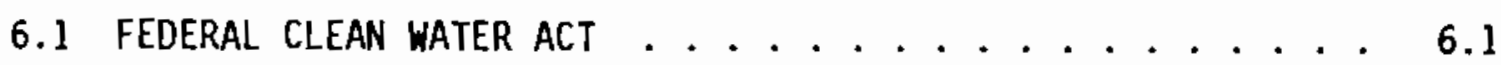

6.2 WASHINGTON WATER POLLUTION CONTROL ACT . . . . . . . 6.2

7.0 OTHER STATE OF WASHINGTON STATUTES AND REGULATIONS RELEVANT

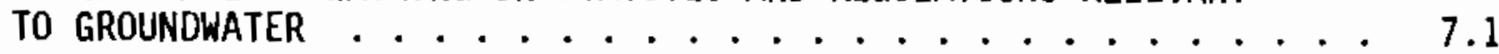

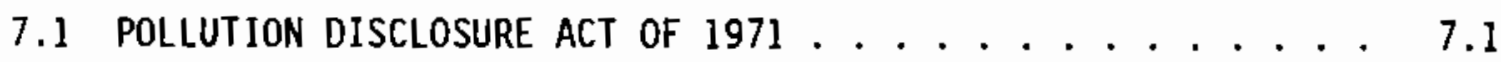

7.2 REGULATION OF PUBLIC GROUNDWATERS ............. 7.2

7.3 WATER WELL CONSTRUCTION ACT OF $1971 \ldots \ldots . \ldots . \ldots . . . \ldots 7$

7.3.1 General Requirements ............ 7.3

7.3.2 Water Supply Well Requirements . . . . . . . 7.4

7.3.3 Resource Protection We1] Requirements...... 7.5

7.3.4 Regulation and Licensing of Water Well Contractors and operators ............... 7.6

7.4 WASHINGTON HAZARDOUS WASTE CLEANUP ACT . . . . . 7.6

8.0 DEPARTMENT OF ENERGY ORDERS . . . . . . . . . . . . . 8.1

8.1 EXISTING DEPARTMENT OF ENERGY ORDERS . . . . . . . 8.1

8.1.1 DOE-RL Order 4330.2 - Water Treatment Plants and Distribution Systems .............. 8.1

8.1.2 DOE Order 5400.I - General Environmental Protection Program, 11-9-88.............. 8.1

8.1.3 DOE Order 5480.1A - Environmental Protection, Safety, and Health Protection Program for DOE

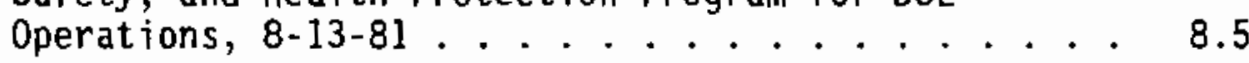

8.1.4 Doe Order 5480.IB - Environmenta] Protection Safety, and Health Program for DOE Operations, 9-23-86 . . 8.6

8.1.5 DOE Order 5480.4 - Environmental Protection, Safety, and Health Protection Standards, 5-15-84 - as amended by DOE Order 5480.4, Chg 1, 5-16-88 . . . 8 8.6 
8.1.6 DOE Order 5484.1 - Environmental Protection, Safety, and Health Protection Information Reporting

Requirements, 2-24-81, as amended by Chg 1, 6-9-81;

Chg 2, 8-13-81; and Chg 3, 11-6-87 ..... 8.6

8.1.7 DOE Order 5820.2A - Radioactive Waste Management,

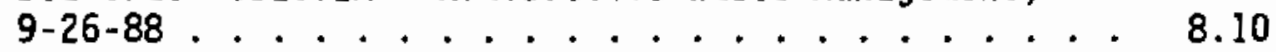

8.2 PROPOSED DEPARTMENT OF ENERGY ORDERS . . . . . . . . 8.11

8.2.1 Proposed DOE Order 5400.XX - Radiation Protection of the Public and the Environment . . . . . . . 8.11

8.2.2 Proposed DOE Order 5400.xy - Radiological Effluent Monitoring and Environmentai Surveillance . . . . . 8.12

8.2.3 Proposed DOE Order 5480.12 - General Environmental Protection Program Requirements ........ 8.12

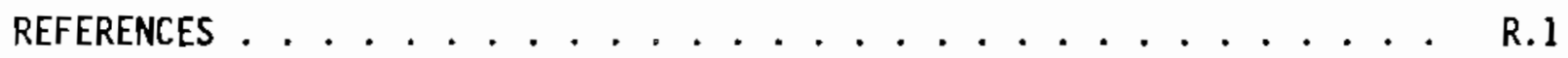




\section{TABLES}

1.1 Current and Proposed Standards for Monitoring and Reporting, Index to Text ..................... 1.5

2.1 Interim Drinking Water Standards ........... 2.9

2.2 Maximum Concentration of Constituents for Groundwater Protection ................... 2.19

$2.3 \mathrm{Classes}$ of Groundwater Protection Permit Modifications . . . 2.43

5.1 Contaminants Required to be Regulated under SDWA 1986 Amendments .................. 5.19

5.2 Drinking Water Priority List . . . . . . . . . 5.20

5.3 Current and Proposed Standards for Bacteria: MCLs, MCLGs, Corrective Action ................ 5.21

5.4 Standards for Bacteria: Monitoring . . . . . . . . . 5.23

5.5 Primary and Secondary Standards for Inorganic Chemical and Physical Contaminants . . . . . . . . . . . 5.24

5.6 Current Standards for Corrosivity . . . . . . . . . . 5.27

5.7 Current Standards for Pesticides ............ 5.28

5.8 Current Standards for Trihatomethanes . . . . . . . . . 5.29

5.9 Current and Proposed Standards for Organic Chemicals . . . . 5.30

5.10 Current and Proposed Standards for Radionuc]ides . . . . . 5.34 


\subsection{INTRODUCTION}

The DOE has been monitoring the Hanford Site for environmental impacts since the 1940s. In the past ten years, new legislation and regulations have been written that contain strict requirements for protecting human health and the environment. This changing regulatory arena has made it necessary to revise the current groundwater monitoring program for the Hanford Site.

Development of a comprehensive groundwater protection, monitoring and reporting program for the Hanford Site is important to ensure the continued protection of public health and the environment from the potential effects of groundwater contamination resulting from past and present waste management practices on the Hanford Site. To develop such a program, the requirements of a number of applicable environmental laws and regulations must be addressed.

The use of other regulatory standards that are not strictly appiicable to the Hanford Site may be important to the development of this program. A11 these standards, both those that the Hanford Site must meet to operate in environmental compliance and those that can be useful goals, are discussed in this report.

\subsection{PURPOSE}

In this report, the environmental pollution control statutes and regulations relating to groundwater protection are reviewed and analyzed. The objective of this report is to provide a detailed review of the regulatory standards useful in developing the Hanford Site groundwater quality protection programs, in assessing regulatory compliance, and in characterizing the Site for remediation work to be undertaken under CERCLA and RCRA corrective action.

This report represents an initial effort to identify all regulations (as of January 1989) pertinent to a comprehensive groundwater protection, monitoring and reporting program for the Hanford Site. It is anticipated that this report will be revised on an annual basis to reflect new and amended statutes and regulations. 


\subsection{SCOPE}

This report provides the regulatory framework under which Hanford managers and technical staff can systematically consider the maze of requirements and guidance in developing a groundwater monitoring and surveillance program. An enhanced understanding of the complex regulatory arena will help technical staff and managers integrate these requirements into the sitewide monitoring program.

The groundwater protection requirements under RCRA and CERCLA are applicable to past and current activities conducted at the Hanford Site. Therefore a substantial portion of this report focuses on the detaits of these requirements.

The drinking water requirements under the SDWA were also assessed because they contain regulatory standards for underground sources of drinking water (USDWs), groundwater classification systems, underground injection control programs, and weilhead protection programs; all of these are important to the development of comprehensive groundwater protection programs.

Several other statutes and regulations that relate to the quality of groundwater were also reviewed. The requirements for protecting surface waters under the federal CWA were assessed for additional information that may be relevant to the development of a Hanford groundwater protection program. In addition, several Washington State statutes and regulations have been reviewed for requirements relating to groundwater quality protection. The DOE Orders have also been assessed for groundwater monitoring and reporting requirements.

This report does not include the groundwater protection standards under the Low Level Radioactive Waste Policy Act, the Nuclear Waste Policy Act; the Toxic Substances Control Act; and the Federal Insecticide, Fungicide, and Rodenticide Act. Nor does it address regulatory agency guidelines and policies pertaining to wellhead protection, nonpoint source pollution management, groundwater classifications, and groundwater protection strategies. These statues, regulations, guidelines, and policies will ultimately need to be addressed as the federal and state regulatory programs in these areas evolve. 


\subsection{BACKGROUND}

Since operations began in the $1940 \mathrm{~s}$, the Hanford groundwater monitoring network has expanded to include over 500 wells across the Site. Groundwater on the Hanford Site is sampled to monitor the distribution of radionuclides and other hazardous materials and to evaluate the impact of past and present site operations on the environment. Non-public drinking water supplies on the Hanford Site are also monitored (see Chapter 8.0). The PNL program monitors contaminants in the groundwater and their migration to other pathways (e.g., the Columbia River). The sitewide monitoring well network is designed to meet the intent of DOE Orders 5480.1 and 5484.1, which are applicable to environmental monitoring. PNL publishes annual reports to document all surface and subsurface monitoring activities at the site and all measured and calculated doses to the public. Other groundwater monitoring activities at the Hanford Site are also being conducted by Westinghouse Hanford Company for compliance with RCRA and/or the Washington Hazardous Waste Management Act (HWMA).

The objectives of sitewide chemical and radiological monitoring are 1) to determine the distribution of certain mobile radionuclides and nitrate ions in order to define the extent of impacted groundwater; 2) to relate the distribution of these constituents to site operations; 3 ) to establish background concentrations for naturally occurring regulated hazardous materials; and 4) to identify hazardous chemicals that have appeared in the groundwater as a result of site operations.

Results from PNL's 1986 monitoring indicated that tritium, nitrate, and certain mobile radionuclides released to the groundwater system continued to migrate slowly, i.e., over tens of years, toward the Columbia River. Plumes of some of these constituents emanate from operating areas within the Hanford Site and enter the river through springs and the river bed at down-gradient locations.

\subsection{REPORT OUTLINE}

Chapter 2.0 outlines the groundwater protection program(s) requirements under RCRA. Groundwater monitoring and reporting requirements for both 
permitted and interim hazardous waste management facilities are presented. Because the Hanford Site is currentiy operating under RCRA interim status, these requirements must be incorporated into comprehensive groundwater protection programs to ensure regulatory compliance. This chapter contains most of the prescriptive information for groundwater monitoring and reporting requirements. Because RCRA is the statute most directly applicable to groundwater monitoring activities at Hanford, RCRA and its implementing regulations are the major focus of this report. Chapter 3.0 presents the groundwater monitoring requirements for nonhazardous waste management facilities which are also regulated under RCRA.

In Chapter 4.0 , the groundwater monitoring requirements under CERCLA are presented. These requirements focus upon site characterization and remediation efforts which are subject to site-specific determinations.

In Chapter 5.0, the monitoring and reporting requirements for public drinking water supplies under the SOWA are presented because of the continuing use of wells as sources of drinking water at several Hanford Site facilities. Current and proposed standards for the protection of drinking water and the required testing frequencies are a1so presented.

Chapter 6.0 provides a brief overview of the CHA. At present there are no federal water quality or monitoring standards for groundwater prescribed under the provisions of the CWA; however, some of the water quality criteria for surface water may be relevant to the development of a groundwater protection program.

Chapter 7.0 provides a brief review of the Washington statutes and regulations that relate to groundwater. In particular, reporting, monitoring, and testing regulations and any prescribed standards are included in this chapter.

In Chapter 8.0, those DOE Orders that contain guidance for protecting the environment have been assessed. The specific requirements for groundwater monitoring and reporting are presented. 
Table l.l provides an index to specific pages in text where monitoring and reporting requirements for RCRA (both interim and permitted), CERCLA, and SDWA are discussed.

TABLE 1.1. Current and Proposed Standards for Monitoring and Reporting, Index to Text

RCRA

Interim Status Facilities

Monitoring

Background

2.8

Asses sment

2.10

Closure

Postclosure

2.13

2.13

Reporting

Permitted Facilities

Monitoring

Background

2.21

Detection

2.23

Compliance

2.26

Corrective Action

2.29

Closure

2.37

Postclosure

2.37

Reporting

CERCLA (Monitoring and Reporting)

Site Characterization

4.1

SDWA (Monitoring and Reporting)

Bacteria

5.23

Primary and Secondary Inorganic Chemical

5.24

and Physical Contaminants

Corrosivity

5.27

Pesticides

5.28

Trihalomethanes

5.29

Organics

5.30

Radionuclides

5.34 



\subsection{REGULATORY REQUIREMENTS FOR HAZARDOUS WASTE MANAGEMENT FACILITIES}

Subtitle C of RCRA governs hazardous waste management. Under Subtitle $C$, hazardous waste management facilities with regulated units must implement a groundwater monitoring program capable of determining the facility's impact on the quality of the groundwater. This chapter reviews the various groundwater monitoring programs under RCRA (40 CFR 240-282) and the implementing regulations (WAC 173-303) of Washington's Hazardous Waste Management Act (RCW 70.105).

\subsection{OVERVIEW OF RCRA}

The Resource Conservation and Recovery Act was enacted in 1976 to provide for "cradle-to-grave" regulation of the generation, transportation, treatment, storage, and disposal of hazardous and nonhazardous solid waste. The primary objectives of RCRA are to protect human health and the environment and to conserve material and energy resources. The Hazardous and Solid Waste Act (HSWA) amendments of 1984 expanded the scope of RCRA. These amendments included corrective action requirements for past and present releases from RCRA-regulated hazardous waste management facilities [referred to as TSD (treatment storage and disposal) facilities]. RCRA, as amended (hereafter referred to as RCRA), can be found at 42 USC 6901-6991; the implementing regulations are available at 40 CFR 124 and 240-282.

The EPA has been authorized by Congress to regulate hazardous solid waste (under Subtitle C) and nonhazardous solid waste (under Subtitle D). Regulations for implementing RCRA Subtitle $C$ for hazardous waste management facilities can be found at 40 CFR 260 through 271 . The EPA has not promutgated regulations for implementing RCRA Subtitie $D$ for nonhazardous solid waste; however, it has published criteria for classifying solid waste disposal facilities (40 CFR 257).

An EPA Notice (51 FR 24504; July 3, 1986) addressed the authority of states to regulate the hazardous components of radioactive mixed wastes under RCRA. The EPA has determined that radioactive mixed waste is considered a "solid waste," and that wastes containing both hazardous and radioactive 
wastes are subject to RCRA regulation. However, the radionuclides themselves are subject to regulation under the Atomic Energy Act.

Although the RCRA hazardous waste program sets up programs that govern the generation, tracking, and transportation of hazardous waste, the analysis contained in this chapter will focus on the treatment, storage, and disposal (TSD) of hazardous waste.

All owners or operators of TSD facilities must apply for an operating permit and must comply with either the 40 CFR 264 or 40 CFR 265 standards. Facilities that are operating under a Part B RCRA permit must meet the requirements of 40 CFR 264. Facilities that qualify for interim status must comply with 40 CFR 265 until final administrative disposition of the Part $B$ permit application or until closure of the hazardous waste management units in accordance with Subpart G of 40 CFR 265. To qualify for interim status, the owner or operator must do all of the following:

1. treat, store, or dispose of hazardous waste, or have commenced facility construction on or before October 21, 1976

2. comply with the 42 USC 3010 notification requirements

3. submit a Part A application under 40 CFR 270.

The Hanford Site is currently operating under a RCRA Part A permit and is, therefore, subject to interim standards. However, approval of RCRA Part B permits for a number of specific waste management units on the Hanford Site is expected during FY 1989. Consequently, the development of a comprehensive groundwater protection strategy requires knowledge of both permitted (40 CFR 264) and interim status (40 CFR 265) facility standards.

\subsection{IMPLEMENTATION OF RCRA}

Under RCRA provisions at 42 USC 6926 and regulations at 40 CFR 271, the EPA is allowed to delegate the authority to implement a hazardous waste management program to individual states. In accordance with these provisions, EPA authorized the WDOE to implement RCRA (minus the HSWA amendments) in January 1986. On September 22, 1987, Washington State requested final authorization for state program revisions developed in response to some of 
the 1984 HSWA Amendments to RCRA. These revisions incorporate the federal redefinition of solid waste, revisions to interim status standards for hazardous waste landfills, and hazardous waste listings, and cover the regulation of radioactive mixed wastes. Washington's program was approved by EPA and became effective on November 22, 1987 (52 FR 35556). EPA is the regulatory agency for the remainder of the 1984 amendments, including corrective action requirements.

In Washington, the Hazardous Waste Management Act (HWMA) and the Solid Waste Management Act (SWMA) provide the statutory authority for implementing RCRA. The HWMA (RCW 70.105) and the regulations at WAC 173-303 set forth the requirements for managing hazardous waste. The purpose of the Washington SWMA (RCW 70.95) and its implementing regulations (WAC 173-304) is to establish a statewide program for handling, recovering and recycling nonhazardous waste in a manner that will prevent land, air and water pollution. This Act is discussed in Chapter 3.

The state hazardous waste management requirements are similar to and are consistent with the federal requirements, as stipulated by RCRA at 42 USC 6926. Although the state has authority to implement RCRA in Washington State, its regulations often incorporate EPA's regulations by reference. Further, under Section 6001 of RCRA, every federal agency must comply with a11 federal, state, interstate, and local requirements governing disposal or management of solid or hazardous waste. Consequently, in this chapter, the state and federal RCRA groundwater monitoring requirements are presented together rather than in two separate chapters.

\subsection{REGULATORY REQUIREMENTS FOR INTERIM STATUS, CLOSURE, AND POSTCLOSURE}

The Hanford Site is currently operating under RCRA interim status. Under interim status, a hazardous waste management facility may continue to operate if it complies with the regulatory requirements of 40 CFR 265 . The DOE is currently submitting RCRA Part B applications and seeking final RCRA permits to continue operating some Hanford units. Other units will be submitting closure and postclosure plans and will not seek a final operating 
permit. The groundwater monitoring and reporting requirements that must be met for interim status operations, closure, and postclosure are reviewed in this section.

The EPA's interim status facility regulations, Subparts $F$ through $R$, found at 40 CFR 265, have been incorporated by reference into Washington's Dangerous Waste Regulations at WAC 173-303-400(3)(a). The state regulations provide that in applying the EPA standards to Washington facilities, the federal term "Regional Administrator" is to be replaced with "Department of Ecology," and the term "hazardous waste" is to be replaced with "dangerous waste." Al1 groundwater reports and notifications must be submitted to WDOE rather than to EPA.

Owners or operators of surface impoundments, landfills, and land treatment facilities under interim status that manage hazardous waste must implement a groundwater monitoring program. Groundwater monitoring requirements for these hazardous waste management units are discussed at 40 CFR 265.90 94. In these regulations, three groundwater monitoring programs are described for interim status facilities: a background monitoring program, an indicator evaluation program, and a groundwater quality assessment plan. Following a discussion of general groundwater monitoring requirements, these three groundwater monitoring programs will be presented (see Sections 2.3 .5 through 2.3.7).

Briefly stated, when a groundwater monitoring system has been installed, a background monitoring program begins. Samples from each monitoring well must be obtained and analyzed quarterly for one year to obtain background data on the quality of the groundwater. After one year, the indicator evaluation program will commence and groundwater samples must be taken semiannually. Data obtained through the indicator evaluation program are compared with background data; if a significant change occurs, a groundwater quality assessment plan must be implemented. Under a quality assessment plan, extensive quarterly testing will be required until the facility is closed. Disposal facilities are further required to maintain quarterly testing throughout the postclosure care period for disposal facilities. 


\subsubsection{Applicability of Interim Status}

As previously stated, the Hanford Site has submitted a RCRA Part A application to EPA Region $X$ and WDOE and is currently operating under interim status. The following discussion, which references the interim status standards ( 40 CFR 265), is applicable until final administrative disposition of a Part B permit application or until specific units are closed in accordance with Subpart $G$ of 40 CFR 265.

The groundwater monitoring requirements of 40 CFR 265 are applicable to the following regulated units: surface impoundments, landfills, or land treatment facilities. Owners or operators of such facilities must implement a groundwater monitoring program that is capable of determining the facility's impact on the quality of groundwater in the uppermost aquifer underlying the facility. The monitoring system must meet requirements for location; sampling and analysis; preparation, evaluation, and response; and recordkeeping and reporting. The groundwater is to be monitored during the active life of the facility. In addition, disposal facilities must continue groundwater monitoring during the closure and postclosure care period (40 CFR 265.90).

Land disposal facilities must continue groundwater monitoring throughout the postclosure care period to ensure that all partial closures and final closure satisfy the closure performance standards (40 CFR 265.112). The postclosure plan is discussed at 40 CFR 265.118; the postclosure plan must include a description of the planned groundwater monitoring activities, of the frequencies at which they will be performed to comply with 40 CFR 265.90 - 0.94, and of the planned maintenance activities and frequencies to ensure that the monitoring equipment is functioning properly. Postclosure care may be reduced or extended if groundwater monitoring results and other criteria indicate that a facility is or is not secure.

\subsubsection{Groundwater Monitoring Waivers or Exemptions for Interim Status}

All or part of the groundwater monitoring requirements may be waived if it can be demonstrated that there is a low potential for hazardous waste constituents from a facility to migrate to water supply wells or to surface water via the uppermost aquifer underlying the facility. This demonstration 
must be in writing at the facility and must be certified by a qualified geologist or geotechnical engineer [40 CFR 265.90(1)].

To determine the potential for hazardous waste constituents to migrate from the facility to the uppermost aquifer, the following must be evaluated:

- a water balance of precipitation, evapotranspiration, runoff, and infiltration

- unsaturated zone characteristics (i.e., geologic materials, physicat properties, and depth to groundwater).

To determine the potential for hazardous waste constituents that enter the uppermost aquifer to migrate to a water supply well or surface water, the following must be evaluated:

- saturated zone characteristics (i.e., geologic materials, physical properties, and rate of groundwater flow)

- the proximity of the facility to water supply wells or to surface water.

\subsubsection{Groundwater Monitoring System Requirements}

The RCRA groundwater monitoring systems must consist of at least one upgradient wel1 and three downgradient wells unless the appropriate waivers are obtained. The number, locations, and depths of the upgradient we17(s) must be sufficient to yjeld groundwater samples that are representative of background groundwater quality in the uppermost aquifer that is near the facility and that is not affected by the facility. The number, locations, and depths of downgradient wells must ensure that any statistically significant quantities of hazardous waste constituents that migrate from the waste management area to the uppermost aquifer are immediately detected [40 CFR $265.91(\mathrm{a})]$.

Separate monitoring systems are not required for each waste management component of a facility provided that monitoring equipment in upgradient and downgradient we1ls can detect any discharge from the waste management area. The waste management area of a facility consisting of only one surface impoundment, landfil1, or 1 and treatment unit is the area on which waste will 
be placed during the active life of the regulated unit [40 CFR 264.95(b)]. The waste management area of a facility consisting of more than one surface impoundment, landfi11, or land treatment area is described by an imaginary boundary line that circumscribes the several waste management components [40 CFR 265.91(b)].

According to 40 CFR $265.91(\mathrm{c})$, all monitoring wells must be cased in a manner that maintains the integrity of the monitoring well boreholes. This casing must be screened or perforated and packed with gravel or sand, where necessary, to enable collection of uncontaminated samples at depths where appropriate aquifer flow zones exist. The annular space (i.e., the space between the borehole and the well casing) above the sampling depth must be sealed with a suitable material (e.g., cement grout or bentonite slurry) to prevent contamination of samples and the groundwater. More detailed construction standards, which may be used as guidance, are found in the Washington water well construction and maintenance regulations (WAC 173-160); these standards are discussed in Chapter 7 of this document.

A groundwater sampling and analysis plan must be developed, followed, and kept at the facility. This plan must include procedures and techniques for

- sample collection

- sample preservation and shipment

- analysis of samples

- chain of custody control [40 CFR 265.92(a)].

\subsubsection{Alternate Groundwater Monitoring System}

An alternate plan for a groundwater monitoring system may be used if an owner or operator assumes or knows that groundwater monitoring of indicator parameters (see Section 2.3.5) would show statistically significant increases (or decreases in the case of $\mathrm{pH}$ ) when evaluated (see Section 2.3.7). A specific alternate system plan, certified by a qualified geologist or geotechnical engineer, must specify

- number, location, and depth of the wells

- sampling and analytical methods 
- evaluation procedures

- implementation schedule [40 CFR 265.90(d)].

This $\mathrm{plan}$ must show that the alternate system is capable of determining the rate and extent of migration and the concentrations of hazardous waste constituents in the groundwater.

\subsubsection{Background Monitoring Requirements}

After a groundwater monitoring system has been installed, the TSD owner or operator must obtain background data to characterize the quality of the groundwater. During the first year that the monitoring system is in operation, quarterly groundwater samples must be taken from each well and analyzed for drinking water parameters, groundwater quality parameters, indicator parameters, and ground water elevation [40 CFR 265.92(c)(1)]. These parameters are discussed in the following paragraphs.

Interim drinking water parameters for which groundwater must be analyzed to determine its suitability as a drinking water source and maximum levels for these parameters are found at 40 CFR 265, Appendix III, and are given in Table 2.1.

Groundwater quality is determined by analyzing samples for the following:

- chloride

- iron

- manganese
- phenols

- sodium

- sulfate.

Parameters that serve as indicators of groundwater contamination are

- $\mathrm{pH}$

- specific conductance

- total organic carbon

- total organic halogen.

For each of the indicator parameters, the arithmetic mean and variance must be calculated from at least four replicate measurements on each sample for each groundwater well that is monitored [40 CFR 265.93(b)]. The initial background arithmetic mean and variance must be determined by pooling the replicate measurements for the respective parameter concentrations or values in samples obtained from upgradient wells during the first year. 


\section{TABLE 2.1. Interim Drinking Water Standards}

\begin{tabular}{lll}
\multicolumn{1}{c}{ Parameter } & & Maximum Level \\
\hline Arsenic & $0.05 \mathrm{mg} / \mathrm{L}$ \\
Barium & $1.0 \mathrm{mg} / \mathrm{L}$ \\
Cadmium & $0.01 \mathrm{mg} / \mathrm{L}$ \\
Chromium & $0.05 \mathrm{mg} / \mathrm{L}$ \\
Fluoride & $1.4-2.4 \mathrm{mg} / \mathrm{L}$ \\
Lead & $0.05 \mathrm{mg} / \mathrm{L}$ \\
Mercury & $0.002 \mathrm{mg} / \mathrm{L}$ \\
Nitrate (as $\mathrm{N})$ & $10 \mathrm{mg} / \mathrm{L}$ \\
Selenium & $0.01 \mathrm{mg} / \mathrm{L}$ \\
Silver & $0.05 \mathrm{mg} / \mathrm{L}$ \\
Endrin & $0.0002 \mathrm{mg} / \mathrm{L}$ \\
Lindane & $0.004 \mathrm{mg} / \mathrm{L}$ \\
Methoxychlor & $0.1 \mathrm{mg} / \mathrm{L}$ \\
Toxaphene & $0.005 \mathrm{mg} / \mathrm{L}$ \\
2,4-D & $0.1 \mathrm{mg} / \mathrm{L}$ \\
2,4,5-TP Silvex & $0.01 \mathrm{mg} / \mathrm{L}$ \\
Radium & $5 \mathrm{pCi} / \mathrm{L}$ \\
Gross Alpha & $15 \mathrm{pCi} / \mathrm{L}$ \\
Gross Beta & $4 \mathrm{millirem/yr}$ \\
Turbidity(a) & $1 / \mathrm{Turbidity} \mathrm{Unit}$ \\
Coliform Bacteria & $1 / 100 \mathrm{ml}$ \\
\hline
\end{tabular}

(a) Turbidity is only applicable to surface waters.

When samples are obtained during the background monitoring period, the elevation of the groundwater must be determined at each well to ensure that the wel15 are properly sited [40 CFR 265.92(e)].

A comprehensive groundwater quality assessment program must be outlined; however, regulations do not establish a time frame for initiating and completing this outline. This groundwater monitoring program must be capable of determining 
- whether hazardous waste constituents have entered the groundwater

- the rate and extent of migration of hazardous waste constituents in the groundwater

- the concentrations of hazardous waste or hazardous waste constituents in the groundwater [40 CFR 265.93(a)].

\subsubsection{Indicator Evaluation Program}

After the 1-year background monitoring period has been completed, an indicator evaluation program must be implemented. Under this program, groundwater samples must be obtained from each monitoring well and analyzed as described below:

- Groundwater quality parameters (chloride, iron, manganese, phenols, sodium and sulfate) must be monitored and analyzed once a year.

- Indicator parameters ( $\mathrm{pH}$, specific conductance, total organic carbon, and total organic halogens) must be monitored and analyzed twice a year.

- The elevation of the groundwater surface must be determined each time a sample is obtained [40 CFR 265.92(e)].

For each of the indicator parameters, the arithmetic mean and variance must be calculated from at least four replicate measurements on each sample for each groundwater well monitored for contamination [40 CFR 265.93(b)]. These resuits should then be compared with the initial background arithmetic mean.

\subsubsection{Groundwater Quality Assessment Program}

If the groundwater underlying a regulated unit is being monitored under an indicator evaluation program (Section 2.3.6) and an indicator parameter increases significantly (or $\mathrm{pH}$ decreases), then a groundwater quality assessment plan must be implemented [40 CFR 265.93(d)(4)].

Under this assessment plan, the rate and extent of migration and the concentrations of the hazardous waste constituents must be determined to assess the groundwater quality as soon as technically feasible. A written 
report containing the results of the assessment must be submitted to WDOE within 15 days after completion of the assessment [40 CFR 265.93(d)(4)].

If the first sampling analyses under an assessment plan indicate that no hazardous waste constituents have entered the groundwater, the indicator evaluation program may be reinstated, but the WDOE must be so notified in the groundwater quality report. If the first assessment plan analyses indicate that hazardous waste constituents have entered the groundwater, the determinations must continue on a quarterly basis for the lifetime of the facility. If the assessment plan was implemented during the postclosure care period, determinations may cease [40 CFR 265.93(d)(6),(7)].

Each we11 in the monitoring system must be considered individually. The student's t-test at the 0.01 level of significance must be used to determine statistically significant increases (and decreases, in the case of $\mathrm{pH}$ ) over initial background values for the indicator parameters.

If the comparisons for the upgradient wells show a significant increase or decrease, this information must be inciuded in the annual report. If the comparisons for the downgradient wells show a significant increase or decrease, additional groundwater samples must be immediately taken from those downgradient wells where a significant difference was detected. The samples should be split in two and analyzed to determine whether the significant difference was due to laboratory error [40 CFR 265.93(c)].

If these analyses confirm the increase or decrease, the WDOE must be notified in writing within 7 days of the confirmation date that the facility may be affecting groundwater quality [40 CFR 265.93(d)(1)].

Within 15 days after the notification, a specific plan for a groundwater quality assessment program must be certified by a qualified geologist or geotechnical engineer and submitted to EPA [40 CFR 265.93(d)(2)]. The assessment plan must specify

- number, location and depth of the wells

- sampling and analytical methods for the hazardous waste or constituents in the facility 
- evaluation procedures, including any use of previously gathered groundwater quality information

- a schedule of implementation [40 CFR 265.93(d)(3)].

In addition to the above requirements, the data on groundwater surface elevation must be evaluated annually to determine whether the monitoring wells are being located in accordance with the regulatory requirements of 40 CFR 265.91. If the evaluation shows that 40 CFR 265.91(a) is no longer satisfied (i.e., at least one hydraulically upgradient and three downgradient wells), the number, location, or depth of the monitoring wells must immediately be modified to bring the groundwater monitoring system into compliance. The surface elevation evaluation does not need to be submitted annually if an assessment plan is in place [40 CFR 265.93(f)].

\subsubsection{Recordkeeping and Reporting}

Recordkeeping and reporting is discussed at 40 CFR 265.94. Records of analyses required for establishing background concentrations, groundwater contamination, and surface elevation during the background monitoring period and under an indicator evaluation plan must be kept through the active life of the facility. Disposal facilities must keep these records through postclosure [40 CFR 265.94(a)(1)].

In the first year when background concentrations are being established, concentrations for drinking water parameters for each well must be reported within 15 days after each quarterly analysis. (Drinking water parameters and their associated concentration levels were discussed in Section 2.3.5). The report must include information for each monitoring well at which the maximum contaminant limit for any parameter is exceeded [40 CFR 265.94(a)(2)(i)].

If an assessment plan is in place, records of the analyses and evaluations specified in the plan must be kept throughout the active life of the facility. For disposal facilities, these records must be kept through the postclosure period. A report containing the results of the groundwater quality assessment program must be submitted to WDOE by March I of each year. This report must include, but is not limited to, the calculated (or measured) 
rate of migration of hazardous waste constituents in the groundwater during the reporting period [40 CFR 265.94 (b)].

An annual report must be submitted that includes the results from the indicator evaluation program, along with the required evaluations (arithmetic mean and variance). Any significant differences from initial background must be reported no later than March 1. Results of the evaluations of groundwater surface elevations and a description of the response to the evaluations must also be included in the March 1 report [40 CFR 265.94(a)(2)(ii)].

The federal (EPA) requirements for recordkeeping at interim status facilities are similar to the Washington State (WDOE) requirements. The major difference between the reporting requirements of WDOE and those of EPA is that EPA requires that a biennial report be submitted (to EPA) by March 1 of each even-numbered year (40 CFR 265.75).

\subsubsection{Closure and Postclosure Care}

Owners and operators of hazardous waste management facilities under interim status must have a written closure $\mathrm{plan}$ and must submit it to WDOE when it is requested. Among other information, the closure plan for regulated units must include a detailed description of groundwater monitoring activities during the closure and postciosure period [40 CFR 265.112(b)(5)].

A written postclosure plan is required if an owner or operator intends to remove all hazardous waste from a surface impoundment or waste pile, or intends to close a facility as a landfill [40 CFR 265.118(a)]. The postclosure plan must include a description of the postclosure groundwater monitoring activities. The postclosure care period will continue for 30 years after a facility closes. However, if the WDOE determines that 30 years is not sufficient to adequately protect human health and the environment, the postclosure period may be extended [40 CFR 265.118(g)(2)].

During this period, the owner or operator must continue to monitor the groundwater in accordance with the applicable monitoring program (indicator evaluation program, or groundwater assessment program) [40 CFR 265.309 (b) (2)]. 


\subsection{REGULATORY REQUIREMENTS FOR PERMITTED FACILITIES}

The RCRA implementing regulations for permitted facilities are found at 40 CFR 264 and the HWMA implementing regulations are found at WAC 173-303. The groundwater protection regulations are discussed at WAC 173-303-645 and refer to Subpart F, "Releases from Solid Waste Management Units," at (40 CFR $264.90-.102)$. These must be complied with until final administrative disposition of the permit application is made.

ATthough the WDOE has received authorization from the EPA to implement RCRA in Washington State and the discussion in this report is focused on state regulations, federal statutes and regulations are applicable and have also been included in this chapter. WDOE has not been granted the authority to implement the 1984 amendments to RCRA, which includes corrective action groundwater monitoring requirements.

Three monitoring and response programs for permitted hazardous waste management facilities are described in the federal and state regulations: detection monitoring, compliance monitoring and corrective action. The facility permit will indicate the appropriate program and requirements for which an owner or operator is responsible. However, if sufficient levels of contaminants are detected in the groundwater, compliance with a program more stringent than that specified in the permit may be required.

Initially, an owner or operator must establish a detection monitoring program which includes the establishment of the background groundwater quality. If hazardous constituents are detected in the groundwater at the compliance point (see Section 2.4.4) of a regulated unit, then a compliance monitoring program must be instituted. If the concentrations of hazardous constituents exceed groundwater limits beyond the compliance point, then a corrective action program must be implemented.

Specific details of these plans (i.e., which hazardous constituents must be tested for, testing frequencies, reporting requirements, etc.) are set forth in the permit. State requirements for monitoring and response programs are similar to the federal requirements. 


\subsubsection{Applicability}

"Ground Water Protection, "WAC 173-303-645, is not currently applicable to the Hanford Site because the Site is operating under interim status. The regulations for interim status must be complied with until final administrative disposition of permit applications. When RCRA final permits (Part B) are obtained, then WAC 173-303-645 will become applicable. Until that time, Subpart $F$ of 40 CFR 265 for interim status facilities is applicable (see Section 2.3).

The regulations in WAC 173-303 apply to facilities that treat, store, or dispose of hazardous waste. Regulated units (surface impoundments, waste piles, landfilis and land treatment units) that receive hazardous waste must comply with the groundwater protection regulations (including the groundwater protection standards) found at WAC 173-303-645 for detecting, characterizing, and responding to releases to the uppermost aquifer. Monitoring of the unsaturated zone is required for 1 and treatment units and may be required for surface impoundments. Waste migrating beyond the waste management area is assumed to originate from the regulated unit unless the owner or operator can prove to the satisfaction of the WDOE that the waste originated from another source.

A11 owners or operators who are seeking a permit for any hazardous waste management unit must comply with the corrective action requirements of WAC 173-303-645(10) to protect human heal th and the environment for all releases of hazardous waste, regardless of the date at which the waste was placed into the units.

The groundwater monitoring requirements apply during the active life and closure of the regulated unit. After closure, they apply if a detection monitoring, compliance monitoring or a corrective action program is being conducted.

\subsubsection{Waivers}

In accordance with Washington's regulations, the groundwater protection standards are not applicable to 
- surface impoundments [except those treating or storing extremely hazardous waste (EHW)], piles or landfills in compliance with WAC 173-303-650(3), $660(1)(c),(3)$, or $(4)$, or $-665(3)$

- treatment zones for which unsaturated zone monitoring shows no statistically significant increase above background levels of dangerous constituents

- regulated units where there is no potential for migration of liquid to the uppermost aquifer (certified by a geologist or geotechnical engineer and based on assumptions that maximize the rate of liquid migration).

After closure of the regulated unit(s), the requirements of WAC 173-303645 do not apply if all waste, waste residues, contaminated containment system components, and contaminated subsoils are removed or decontaminated to the limits of WAC 173-303-610(2)(b).

Under the federal regulations, regulated units are not subject to reguTatory control for releases to the uppermost aquifer if EPA finds that the regulated unit is an engineered structure that

- does not receive or contain iiquid waste or waste containing free 1 iquids

- is designed and operated to exclude liquid, precipitation and other run-on and run-off

- has both inner and outer layers of containment enclosing the waste

- has a leak detection system that is built into each containment layer and that will be maintained through postclosure

- will prevent hazardous constituents from migrating beyond the containment layer before postclosure care ends [40 CFR 264.90(b)(2)].

The EPA may also grant a waiver from postclosure requirements if it determines that levels of hazardous constituents in the treatment zone of a 7 and treatment unit do not exceed background levels by a statistically significant amount and if unsaturated zone monitoring shows that hazardous constituents below the treatment zone did not increase significantiy during the operating life of the unit [40 CFR 264.90(b)(3)]. 
A waiver may also be granted if EPA finds there is no potential for liquid migration to the uppermost aquifer through postclosure care. This demonstration must be certified by a geologist or geotechnical engineer. All predictions will be based on assumptions that maximize the rate of liquid migration [40 CFR 264.90(b)(4)].

\subsubsection{Groundwater Protection Standard}

A facility's groundwater protection standard is established by the WDOE in the permit WAC 173-303-645. The permit conditions are designed to ensure that dangerous constituents entering the groundwater from a regulated unit do not exceed the concentration limits in the uppermost aquifer underlying the waste management area during the compliance period.

The permit will specify the dangerous constituents to which the groundwater protection standard applies [WAC 173-303-645(3)]. The WDOE may also specify in the permit the indicator parameters (specific conductance, $\mathrm{pH}$, total organic carbon, total organic halogen, or heavy metals), waste constituents, or reaction products identified in the detection monitoring program that reliably indicate the presence of dangerous constituents in the groundwater. Dangerous constituents are constituents listed in 40 CFR 264, Appendix IX. In addition, dangerous constituents are any other constituents that have caused a waste to be regulated under WAC 173-303, been detected in the uppermost aquifer underlying a regulated unit, and that are reasonably expected to be in or derived from waste in a regulated unit. The WDOE may exempt specific Appendix IX constituents if the constituents do not pose substantial present or potential hazards to the environment. In granting an exemption, HDOE will consider the potential adverse effects on groundwater and on the quality of hydrautically connected surface water. Factors considered include the following:

- volume and physical and chemical characteristics of the waste, including potential for migration

- hydrogeological characteristics of the facility and surrounding land 
- quantity and quality of the groundwater and direction of its flow

- proximity of users and rate at which groundwater is withdrawn

- proximity of the regulated unit to surface waters

- rainfall patterns (for surface water)

- current and future uses of groundwater or surface water in that area, including any established water quality standards

- existing quality of groundwater or surface water, including other sources of contamination and their cumulative impact on water quality

- potential for health risks

- potential for damage to wildlife, crops, vegetation, and physical structures

- the persistence and permanence of the potential adverse effects [WAC $173-303-645(5)(b)$ ].

Furthermore, in granting an exemption, WDOE will consider any identification of underground sources of drinking water and exempted aquifers made pursuant to RCW 90.48, WAC 173-208 and other applicable state laws and regulations.

Concentration limits for dangerous constituents in the groundwater will be specified by WDOE in the permit [WAC 173-303-645(5)(a)]. The concentra$t i$ on of a dangerous constituent must not exceed the background level in the groundwater. The concentration for any of the constituents in Table 2.2 must not exceed the respective value in Table 2.2 or must not exceed an alternate limit estab] ished by WDOE.

The WDOE has the authority to establish alternate concentration limits (ACLs) for dangerous constituents provided that the environment is protected. The factors to be considered in establishing ACLs are the same as those previously discussed (i.e., potential adverse effects on groundwater quality and on hydraulically connected surface water quality and impacts to underground sources of drinking water and exempted aquifers) [WAC 173-303$645(5)(b)]$. 

TABLE 2.2. Maximum Concentration of Constituents for
Groundwater Protection

\begin{tabular}{|c|c|}
\hline Constituent & $\begin{array}{c}\text { Concentration } \\
(\mathrm{mg} / \mathrm{L})\end{array}$ \\
\hline Arsenic & 0.05 \\
\hline Barium & 1.0 \\
\hline Cadmium & 0.01 \\
\hline Chromium & 0.05 \\
\hline Lead & 0.05 \\
\hline Mercury & 0.002 \\
\hline Selenium & 0.01 \\
\hline Silver & 0.05 \\
\hline $\begin{array}{l}\text { Endrin }(1,2,3,4,10,10-\text {-hexachloro- } \\
1,7 \text {-epoxy-1,4,4a,5,6,7,B,9a- } \\
\text { octahydro-1, 4-endo, endo-5, } \\
\text { dimenthano naphtha? ene })\end{array}$ & 0.0002 \\
\hline $\begin{array}{l}\text { Lindane }(1,2,3,4,5,6 \text {-hexachloro- } \\
\text { cyclohexane, gamma isomer) }\end{array}$ & 0.004 \\
\hline $\begin{array}{l}\text { Methoxychlor (1,1,1-Trichloro-2,2- } \\
\text { bis (p-methoxyphenylethane) }\end{array}$ & 0.1 \\
\hline $\begin{array}{l}\text { Toxaphene }\left(\mathrm{C}_{10} \mathrm{H}_{10} \mathrm{CL}_{6} \text { Technical }\right. \\
\text { chlorinated camphene, } 67-69 \\
\text { percent chlorine }\end{array}$ & 0.005 \\
\hline $\begin{array}{l}2,4-D(2,4-D i c h l o r o p h e n o x y a c e t i c \\
\text { acid) }\end{array}$ & 0.1 \\
\hline $\begin{array}{l}\text { 2,4,5-TP Silvex }(2,4,5 \text {-Trichloro- } \\
\text { phenoxypropionic acid) }\end{array}$ & 0.01 \\
\hline
\end{tabular}

(a) 40 CFR 264.94, Table 1.

The groundwater protection standard established by EPA is similar to WDOE's standard established at WAC 173-303-645(3). EPA will, to the extent practical, establish the standard at the time the permit is issued. 


\subsubsection{Point of Compliance}

The point at which the groundwater protection standard applies is called the point of compliance. The point of compliance is a vertical surface located at the hydraulically downgradient limit of the waste managenent area and extending down into the uppermost underlying aquifer [WAC 173-303$645(6)(a)]$. In the permit, the WDOE will specify the point of compliance at which the groundwater protection standard of WAC 173-303-645(3) applies and at wich monitoring must be conducted. WDOE may specify closer points of compliance considering the risks of the facility, the wastes and constituents managed by the facility, the potential for waste constituents to have already migrated past the alternate compliance point, and the potential threats to ground and surface waters.

The waste management area is the "limit projected in the horizontal plane of the area on which waste will be placed during the regulated unit's active life." This area includes horizontal space taken up by any liner, dike, or other barrier designed to contain waste. If the facility consists of more than one unit, the waste management area is described by an imaginary line circumscribing the several regulated units [WAC 173-303-645(6)(b)]

\subsubsection{Compliance Period}

The WDOE will specify in the permit the compliance period during which the groundwater protection standard applies. The compliance period is the number of years the waste management area is active and begins when a compliance monitoring program is initiated. In most instances, this period extends through closure and postclosure. If a corrective action program is necessary, the compliance period will continue until the groundwater protection standard has not been exceeded for 3 consecutive years [WAC 173-303-645(7)]

\subsubsection{General Groundwater Monitoring Requirements}

Any groundwater monitoring system developed for detection monitoring, compliance monitoring, or corrective action must consist of a sufficient number of wells, installed at appropriate locations and depths, to yield groundwater samples from the uppermost aquifer. These samples must represent 
the quality of background water that has not been contaminated by leachate and the quality of groundwater passing the point of compliance [WAC 173-303-645(8)(a)].

Facilities with more than one regulated unit may not be required to have separate groundwater monitoring systems for each unit. If sampling the groundwater in the uppermost aquifer from one system will enable detection and measurement of dangerous constituents at the compliance point, one system may be adequate [WAC 173-303-645(8)(b)].

All monitoring wells must be cased to maintain the integrity of the borehole. This casing must allow collection of representative samples. Wells must be constructed in such a manner as to prevent contamination of the samples, of the sampled strata, and between aquifers and water-bearing strata [WAC $173-303-645(8)(c)]$.

The groundwater monitoring program must include procedures and techniques to ensure consistent collection, preservation, shipment, analysis, chain of custody control for samples, and decontamination of sampling and drilling equipment [WAC 173-303-645(8)(d)]. In addition, the program must include consistent sampling and analytical methods that ensure reliable groundwater sampling, accurately measure dangerous constituents and indicator parameters, and provide a reliable indication of groundwater quality below the waste management area [WAC 173-303-645(8)(e)].

\subsubsection{Background Monitoring}

To establish a reference point for future comparisons, the quality of the groundwater must be determined. Generally, background data will be obtained from upgradient monitoring wells; however, background quality may be based on samples from wells that are not upgradient if 1) the hydrogeologic conditions do not allow a determination of what wells are upgradient, or 2) sampling at other wells will indicate background quality that is as representative or more representative than samples provided by upgradient wells [WAC 173-303-645(8)(g)]. To develop a database of background values, a minimum of one sample from each well and a minimum of four samples from the entire system will be used to determine background quality each time the 
system is sampled. Each time the groundwater is sampled, the elevation of the surface of the groundwater must be measured.

Background quality may be established under either a detection monitoring or a compliance monitoring program. In a detection program, background quality must be based on quarterly sampling data from upgradient welis for one year. In a compliance program, background quality must be based on upgradient well data that were available before the permit was issued, that account for errors in sampling and analysis, and that account for seasonal fluctuations in background groundwater qua] ity [WAC 173-303-645(8)(g)].

The following statistical procedure must be used in a detection monitoring program to determine whether background values or concentration 1 imits have been exceeded. If the level of a constituent at the compliance point is to be compared with a background value having a sample coefficient of variation less than 1.00 , at least four portions must be taken from a sample at the compliance point at each well. The difference between the mean of the constituent and the background value must be determined. If the Cochran's Approximation to the Behrens-Fisher Student's t-test (as described in Appendix IV of 40 CFR 264) indicates a significant difference at the 0.05 level, the procedure must be repeated with a new sample. If the second analysis indicates that the difference is significant, it must be concluded that a statistically significant change has occurred.

An equivalent statistical procedure may be used in lieu of the above if WDOE determines that the alternative procedure reasonably balances the probability of falsely identifying a noncontaminated regulated unit and the probability of failing to identify a contaminating regulated unit [WAC 173$303-645(8)(h)(i)]$.

For routine analyses under detection and compliance monitoring programs, a statistical procedure must be used that provides reasonable confidence that the migration of dangerous constituents from a regulated unit into and through the aquifer will be indicated. The WDOE will specify a statistical procedure in the permit that adequately establishes background values and provides a balance between falsely identifying a unit and failing to identify a unit [WAC 173-303-645(8)(h)(ii)]. 
The EPA has recent7y adopted new statistical analyses procedures. These procedures are discussed in Section 2.5, "Recent Regulatory Changes."

\subsubsection{Detection Monitoring Program}

If an owner or operator of a regulated unit is not required to implement a compliance monitoring program or a corrective action $\mathrm{plan}$, then a detection monitoring program must be instituted [40 CFR 264.91(4)]. The permit for the regulated unit will specify the appropriate groundwater monitoring program. Indicator parameters (specific conductance, $\mathrm{pH}$, total organic carbon, total organic halogen, or heavy metals), waste constituents, or reaction products that reliably indicate the presence of dangerous constituents in the groundwater must be monitored in a detection program. In specifying the parameters or constituents in the permit, the WDOE will consider the following:

- types, quantities and concentrations of the waste constituents

- mobility, stability, and persistence of the waste constituents and their reaction products in the unsaturated zone beneath the waste management area

- detectability of indicator parameters, waste constituents, and reaction products in the groundwater

- concentrations or values and coefficients of variation of proposed monitoring parameters or constituents in the background groundwater [WAC 173-303-645(9)(a)].

A groundwater monitoring system must be installed at the compliance point in accordance with WAC 173-303-645(6) and - 645(8)(a)(ii), (b) and (c). A background value for each parameter or constituent must also be estab1 ished. The permit will specify the procedures that must be used to calculate the values. The provisions of WAC 173-303-645(8)(g) and $(\mathrm{h})$ must also be complied with in developing the background database and determining statistically significant increases. Samples that will be used to determinate background values must be taken from a groundwater monitoring system that complies with WAC 173-303-645(8)(a)(i), (b) and (c).

Groundwater quality at each monitoring well at the compliance point must be determined at least semi-annually through postclosure. The data must be 
in a form that is appropriate for determining statistically significant increases. At least annualiy, the groundwater flow rate and direction in the uppermost aquifer must be determined. Sampling and analysis procedures and methods must meet the requirements of WAC 173-303-645(8)(d) and (e).

Each time groundwater quality at the compliance point is determined, any parameter or constituent specified in the permit must also be analyzed to determine whether it has a statistically significant increase over background leve1. This must be done within a reasonable period of time after sampling. The WDOE will specify what is reasonable after considering the complexity of the statistical test and the availability of laboratories to analyze the groundwater samp]es [WAC 173-303-645(9)(g)].

If there is a statistically significant increase in any indicator parameters, the EPA must be notified in writing within 7 days [WAC 173-303$645(9)(h)]$. The notification must indicate what parameters or constituents have shown statisticaliy significant increases. Furthermore, the groundwater in all monitoring wells must be sampled and analyzed for the presence of the constituents in Appendix IX in 40 CFR 264 and for all other dangerous constituents specified in the facility permit. (Appendix IX is a new groundwater monitoring list that contains over 200 chemicals.) Background values for each constituent found at the compliance point must be established by

- complying with WAC 173-303-645(8)(g) in developing the background value's database

- expressing background values in a form appropriate for determining statistically significant increases

- using a groundwater monitoring system that complies with WAC 173$303-645(8)(a)(i),(b)$ and (c).

Within 45 days of determining a statistically significant increase, either an application for a permit modification to establish a compliance monitoring program or a demonstration must be submitted to WDOE. If the increase was caused by a source other than the regulated unit or by error in 
sampiing, analysis, or evaluation, a demonstration (petition for dismissal of erroneous testing resuits) can be made to WDOE in addition to, or in lieu of, submitting a permit modification.

In making a demonstration, the owner or operator must:

- within 7 days of determining a statistically significant increase at the compliance point, notify WOOE in writing of the intent to make a demonstration

- within 45 days from date of determination, submit a demonstration report

- within 45 days from date of determination, submit a permit modification to make appropriate changes to the detection program

- continue to monitor in accordance with the detection monitoring program [WAC 173-303-645(9)(i)].

If a demonstration will not be made, a permit modification must be submitted to WDOE within 45 days.

An application for a permit modification to establish a compliance monitoring program must meet the following requirements:

- identify the concentration of each constituent in the groundwater at each monitoring well at the compliance point

- propose changes in the monitoring system to meet the compliance monitoring requirements of WAC 173-303-645(10)

- propose changes to the monitoring frequency, sampling and analysis procedures or methods, or statistical procedures to meet WAC 173$303-645(10)$

- propose a concentration limit for each dangerous constituent found at the compliance point or give a notice of intent to seek a variance under WAC 173-303-645(5)(b) [WAC 173-303-645(9)(h)(iv)].

Within 90 days, WDOE must receive all data necessary to justify a variance. An engineering feasibility plan for a corrective action program [WAC 173-303-645(11)] must also be supplied unless all identified 
constituents are those shown in Table 2.2 and their concentrations do not exceed the values shown in Table 2.2. If the owner or operator decides to seek a variance for every Appendix IX constituent and every constituent identified in the facility permit, an engineering feasibility plan need not be submitted.

If the detection monitoring program no longer meets the requirements of WAC 173-303-645(9), an appiication for a permit modification must be made within 45 days [WAC 173-303-645(9)(j)]. AIl monitoring and corrective action measures necessary to achieve compliance with the groundwater protection standard under WAC 173-303-645(3) must occur during the term of the permit [WAC 173-303-645(9)(k)].

The federal requirements found in 40 CFR 264.98 are similar to those of WDOE; however, EPA includes heavy metals as an indicator parameter. The statistical procedures in the federal regulations have recently been revised and now differ from these used by WDOE. These procedures are discussed in detail in Section 2.5. Under the federal regulations, if the owner or operator cannot demonstrate that a statistically significant increase in a parameter has been caused by another source or is the result of a sampling error, an application for a permit modification to establish a compliance monitoring program must be submitted to EPA within 90 days. Within 180 days, EPA must receive al1 data to justify a variance and an engineering feasibility plan for a corrective action program. The WDOE requires the latter information within 90 days. Except for the 7-day requirements, a 11 time frames for submitting documentation to WDOE are usually one-half the time required by EPA.

\subsubsection{Compliance Monitoring Program}

An owner or operator of a regulated unit may be required to institute a compliance monitoring program. The facility permit will specify whether or not a compliance monitoring program must be instituted. If a regulated unit is under a detection monitoring program and WDOE determines that any requirement of RCRA is being violated or that there is an imminent hazard, a compliance or enforcement order may be issued, and the facility could be required to institute a compliance monitoring program. Finally, if dangerous 
constituents are detected in the groundwater underlying a regulated unit, the owner or operator also must institute a compliance monitoring program.

If a compliance program must be established, the groundwater must be monitored to determine which regulated units are in compliance with the groundwater protection standard specified in the permit. The permit will

- provide a list of dangerous constituents [WAC 173-303-645(4)]

- set concentration limits for each [WAC 173-303-645(5)]

- estab7ish the compliance point [WAC 173-303-645(6)]

- establish the compliance period [WAC 173-303-645(7)].

A groundwater monitoring system must be installed at the compliance point [WAC 173-303-645(6)] and must comply with WAC 173-303-645(8)(a)(ii), (b) and (c). If a concentration limit is based on background quality, WDOE will specify the concentration limit in the permit as follows:

- If there is a high temporal correlation between upgradient and compliance point concentrations, the concentration limit may be established by sampling at upgradient wells each time the groundwater is sampled at the compliance point. The WDOE will specify the procedures used to determine the concentration limit. In all other cases, the concentration will be the mean of the pooled data on the concentration of the dangerous constituent.

- If a dangerous constituent from Table 2.2 is identified and the statistical analysis does not indicate a significant increase, the background value must be used as the concentration limit. The statistical procedure must be appropriate for the distribution of the data used to establish background values and must provide a balance between falsely identifying and failing to identify a significant difference [WAC 173-303-645(10)(c)(i), (ii)].

The owner or operator must use a groundwater monitoring system that complies with WAC 173-303-645(a)(i), (b) and (c). The database of background values must be developed in accordance with WAC 173-303-645(8)(g), and background values must be expressed in a form appropriate to determine statistically significant increases [WAC 173-303-645(8)(h)]. 
The concentration of dangerous constituents in groundwater at each monitoring well at the compliance point must be determined at least quarterly during the compliance period. At least annually, the rate and direction of groundwater flow in the uppermost aquifer must be determined [WAC 173-303$645(10)(d)$ and (e).

Samples must be taken from all monitoring wells at the compliance point and analyzed to determine whether Appendix IX (40 CFR 264) constituents or any other constituents identified in the facility permit are present. If present, their concentrations must be determined. The analysis must be conducted at least annualiy to determine whether additional Appendix IX constituents are present in the uppermost aquifer. If Appendix IX constituents that are not already identified in the permit as monitoring constituents are found in the groundwater, their concentrations must be reported to WDOE within 7 days after the analysis has been completed [WAC 173-303-645(10)(f)].

If the groundwater protection standard is being exceeded at any monitoring well at the compliance point, WDOE must be notified in writing within 7 days. The notification must indicate which concentration limits have been exceeded. An application to establish a corrective action progran must be submitted to WDOE within 90 days. If an engineering feasibility study has been previously submitted, the application for permit modification must be submitted to WDOE within 60 days. For units managing EHW, time frames of 60 days and 45 days for the permit modification application and the engineering feasibility study, respectively, will apply. However, if WOOE determines that the 90/60-day or the 60/45-day periods increase the threat to the environment, it may specify shorter limits. The application for a permit modification must include the following information:

- detailed description of corrective actions for achieving compliance

- a monitoring program plan that will demonstrate the effectiveness of the corrective action [WAC 173-303-645(10)(h)(iii)].

The owner or operator may again demonstrate that some other source or a statistical error is responsible for the increase. The WDOE must be notified 
within 7 days that a demonstration will be made. Within 45 days, a demonstration and a permit modification application must be submitted to WDOE [WAC 173-303-645(10)(i)].

During the demonstration period, monitoring in accordance with the compliance monitoring program must continue. If the compliance program no longer satisfies applicable requirements, the program can be modified. However, monitoring and corrective action measures necessary to achieve compliance with the groundwater protection standard under WAC 173-303-645(3) must be taken during the term of the permit.

Federal requirements found at 40 CFR 264.99 are similar to the Washington State requirements at WAC 173-303-645(10). Permit modification applications to EPA must be submitted within 90 days ( 45 days to WDOE). The EPA time frames for submitting modification applications do not change if an engineering feasibility study has previously been submitted.

\subsubsection{Corrective Action Program}

Corrective action measures may be specified in the facility's permit or may be required to comply with an enforcement or compliance order. In addition, whenever the groundwater protection standard established under WAC 173-303-645(3) is exceeded or the concentration limits of the dangerous constituents 7isted at WAC 173-303-645(5) are exceeded between the compliance point and the facility boundary, a corrective action program must be instituted [WAC 173-303-645(11)(a)].

An owner or operator who is required to establish a corrective action program for regulated units that received waste after July 26, 1982, must ensure that regulated units comply with the groundwater protection standard as specified in the permit. The corrective action plan must include

- a list of dangerous constituents

- concentration limits for each

- the compliance point

- the compliance period [WAC 173-303-645(11)(a)].

Where necessary to protect human health and the environment, the corrective action program must remove or treat in place any dangerous constituents 
that exceed concentration limits in the groundwater between the compliance point and the downgradient facility boundary and beyond the facility boundary [WAC 173-303-645(11)(b), (e)].

A corrective action program must begin within a reasonable period of time after the groundwater protection standard is exceeded. The WDOE will specify the time period in the permit [WAC 173-303-645(11)(c)]. If the permit contains both a corrective action program and a compliance monitoring program, the permit will specify when corrective action will begin. This requirement will replace the corrective action application of WAC 173-303$645(10)(i)(i i)$.

A groundwater monitoring program must be implemented in conjunction with a corrective action program to demonstrate the effectiveness of the corrective action program. Such a program must be based on the requirements for a compliance monitoring program. In addition, it must be as effective in determining compliance with the groundwater protection standard and in determining the success of a corrective action program as the progran required by the regulations [WAC 173-303-645(11)(d)].

Corrective action must be completed within a reasonable period of time considering the extent of contamination and must continue as long as necessary to ensure that the groundwater protection standard is not exceeded. When the dangerous constituents have been removed or treated in place and the concentrations of dangerous constituents have been reduced to levels below their concentration 7 imits, corrective action measures can be terminated. Postclosure monitoring can be terminated when the standard has not been exceeded for three consecutive years [WAC 173-303-645(11)(e)(f)].

Semi-annual reports on the effectiveness of the corrective action program must be submitted to WDOE. If the program is no longer satisfactory, an application for permit modification must be submitted to WDOE within 45 days [WAC $173-303-645(11)(g)$ and $(h)]$.

The EPA program, found at 40 CFR 264.100 is similar to WDOE's except that EPA requires 90 days notice for permit modification, while WDOE requires 45 days. Furthermore, the federal regulations state that al1 solid waste management units must comply with the corrective action requirements of 
40 CFR 264.101. These requirements state that corrective action must be instituted to protect the environment from all releases of dangerous waste or dangerous waste constituents, regardiess of when the waste was placed in the unit. Additionally, EPA's regulations have provisions for corrective action measures beyond the facility boundary. Cleanup beyond the facility boundary is not necessary if the EPA is satisfied that the owner or operator has tried but has been unable to obtain the necessary permission to undertake such action. However, owners and operators are not relieved of all responsibility to clean up a release that has migrated beyond the facility boundary where off-site access is denied. On-site measures to address such releases will be determined on a case-by-case basis [40 CFR 264.100(a)(d)].

\subsubsection{Recordkeeping and Reporting}

Monitoring records must be kept at the facility. All permits will specify requirements for proper monitoring methods and for the proper use, maintenance, and installation of monitoring equipment. The permit will also specify the required monitoring, including type, intervals, and frequency, that will yield representative data.

Recordkeeping requirements for a permitted facility, including monitoring information, are found at WAC 173-303-810(11). The permittee must keep a) 1 monitoring information including data, calibration and maintenance records, and all original strip chart recordings for at least three years from the date of sample measurement. Groundwater surface elevation data from all monitoring wells must be kept for the active life of the facility, including the postclosure period. Records for monitoring information must include the following:

- the date, exact place, and time of sampling or measurements

- the individual(s) who performed the sampling or measurements

- the date(s) anatyses were performed

- individual(s) who performed the analyses

- analytical techniques or methods used

- results of such analyses [WAC 173-303-810(11)].

Monitoring results must be reported at the frequencies specified in the permit [WAC 173-303-810(14)(d)]. 
In a detection monitoring program, the groundwater quality of each monitoring well at the compliance point must be determined at least semiannualiy through postclosure HAC 173-303-645(9)(d). At least annually, the groundwater flow rate and direction in the uppermost aquifer must be determined [WAC 173-303-645(9)(e)]. If there is a statistically significant increase over the background level for any constituent, WDOE must be notified in writing within 7 days. Within 45 days, a permit modification application to develop a compliance monitoring program must be submitted to WDOE [WAC 173-303-645(9)(i)].

In a compliance monitoring program, the concentration of dangerous constituents at each monitoring well at the compliance point must be determined at least quarterly during the compliance period. The groundwater flow rate and direction in the uppermost aquifer must be determined at least annually [WAC 173-303-645(10)(d)(e)]. The Appendix IX analyses must be conducted annually to determine whether additional dangerous constituents are present in the uppermost aquifer. The concentrations of all detected constituents must be reported to WDOE within 7 days after the analysis is completed [WAC 173-303-645(10)(f)]. If the groundwater protection standard is being exceeded at any monitoring well at the compliance point, the WDOE must be notified within 7 days, and a permit modification application to establish a corrective action program must be submitted to WDOE within 90 days [WAC 173$303-645(10)(i)]$.

In a corrective action program, semi-annual reports on the effectiveness of the program must be submitted to WDOE [WAC 173-303-645(11)(g)].

A1] reports required by permits or other information requested by WDOE must be signed by the operator or a duly authorized representative. A person is authorized only if the authorization is made in writing by the operator of the facility and submitted to WDOE. A duly authorized representative is either a named individual or any individual occupying a named position [WAC 173-303-810(12)(b)].

Reports of anticipated noncompliance with a permit must be submitted to WDOE. Monitoring reports must be submitted as required in the permit. Reports of permit compliance or noncompliance or any progress reports on any 
requirements contained in a compliance schedule must be submitted no later than 14 days following each date scheduled in the permit. [WAC 173-303$810(14)(c)(e)]$.

Washington State also has immediate reporting requirements. Any noncompliance that endangers the environment must be communicated to WDOE verbaliy as soon as the permit holder is aware of the circumstances. A written submission must be provided to WDOE within 5 days. This submission must contain

- a description of the noncompliance and its cause

- the period of noncompliance, including exact dates and times

- if noncompliance has not been corrected, the anticipated time it is expected to continue

- the steps taken or planned to reduce, eliminate, and prevent recurrence of the noncompliance [WAC 173-303-810(14)(f)].

Information to be reported immediately includes release of dangerous waste that may endanger drinking water supplies, groundwater, or surface water; release or discharge of dangerous waste that could threaten the environment outside the facility; and a description of the occurrence. This description should include

- the name, address, and telephone number of the owner or operator

- the name, address, and telephone number of the facility

- the date, time, and type of incident

- the name and quantity of material(s) involved

- the extent of injuries, if any

- an assessment of actual or potential hazards to the environment

- an estimate of the quantity and disposition of recovered material that resulted from the incident. [WAC 173-303-810(14)(f)].

The WDOE must be notified of any noncompliance that has not been immediately reported or submitted within the monitoring and compliance schedule reports [WAC 173-303-810(g)]. 


\subsubsection{Final Facility Permit (Part B) - Groundwater Monitoring Requirements}

Owners or operators of hazardous waste management facilities that are required to have a Part $B$ permit must submit an application in accordance with WAC 173-303-806. The Part B application includes groundwater protection requirements for dangerous waste surface impoundments, land treatment units, piles and landfills [WAC 173-303-806(4)(a)(xx)].

The following information must be included as part of the Part B permit for a regulated unit:

- a summary of the groundwater monitoring data obtained during interim status (when applicable)

- identification of the uppermost aquifer and the hydraulically interconnected aquifers underlying the facility boundaries, groundwater flow rate, and direction

- on the topographic map [as required under WAC 173-303$806(4)$ (a) (xviji), a delineation of the waste management area, the property boundary, the proposed point of compliance, the proposed location of groundwater monitoring wells, and, to the extent possible, the information required in the previous bulleted item

- a description of any plume of contamination that has entered the groundwater from a regulated unit at the time that the application was submitted; the description is to

- delineate the extent of the plume on the topographic map required

- identify the concentration of each Appendix IX (40 CFR Part 264) constituent (and other constituents identified in the permit) throughout the plume or identify the maximum concentrations of each Appendix IX constituent in the piume

- detailed plans and an engineering report describing the proposed groundwater monitoring program to be implemented to meet the requirements of WAC 173-303-645(8).

If no dangerous constituents have been detected in the groundwater by the time the Part B application is submitted, a detection monitoring program 
must be established to meet the requirements of WAC 173-303-645(a) (described in detail in Section 2.4.8). Sufficient information, supporting data, and anaiyses must be submitted in accordance with the detection monitoring requirements and must include the following [WAC $173-303-806(4)(a)(x x)(F)]$ :

- a proposed list of indicator parameters, waste constituents, or reaction products that can provide a reliable indication of the presence of dangerous constituents in the groundwater

- a proposed groundwater monitoring system

- background values for each proposed monitoring parameter or constituent, or procedures to calculate such values

- a description of proposed sampling, analysis and statistical comparison procedures to be used in evaluating groundwater monitoring data.

If dangerous constituents have been detected in the groundwater at the point of compliance before the permit application has been submitted, then sufficient information must be submitted to establish a compliance monitoring program in accordance with WAC 173-303-645(10) (described in detail in Section 2.4.9). In addition, an engineering feasibility plan for a corrective action program must be submitted. To establish a compliance plan, the Part $B$ app]ication must include the following [WAC 173-303-645(4)(a)(xx)(G)]:

- a description of the wastes previously handled at the facility

- a characterization of the contaminated groundwater, including concentrations of dangerous constituents

- a list of dangerous constituents and parameters for which compliance monitoring will be undertaken in accordance with WAC 173-303$645(8)$ and (10)

- proposed concentration limits for each dangerous constituent, based on the criteria set forth in WAC 173-303-645(5)(a), including a justification for establishing any alternate concentration 1 imits 
- detailed plans and an engineering report describing the proposed groundwater monitoring system, in accordance with the requirements of WAC 173-303-645(8)

- a description of proposed sampling, analysis and statistical comparison procedures to be used in evaluating groundwater monitoring data.

If the concentration limits established in Table 2.2 have been exceeded, or if dangerous constituents in the groundwater have exceeded background concentrations before a Part B application has been submitted, then the necessary information to establish a corrective action program must be included in the permit application. However, if it can be demonstrated to the regulatory agency that alternate concentration 1 imits will protect human heaith and the environment in accordance with the criteria of WAC 173-303-645(5), then information may be submitted to establish a compliance monitoring program. The information necessary to establish a corrective action monitoring program as described at WAC 173-303-645(11) and Section 2.4.10, must include the following [WAC 173-303-806(4)(a) (xx)(H)];

- a characterization of the contaminated groundwater, including concentrations of dangerous constituents and parameters

- the concentration limit, as set forth at WAC 173-303-645(5), for each dangerous constituent found in the groundwater

- detailed plans and an engineering report describing the corrective action to be taken

- a description of how the groundwater monitoring program will demonstrate the adequacy of the corrective action

- a schedule for submittal of the information required in WAC 173303-806(4)(a)(xx)(H) III and IV, provided the owner or operator obtains written authorization from the regulatory agency prior to submittal of the permit application.

In addition to the above requirement, a Part $B$ application must include a copy of the closure $\mathrm{plan}$ and, when applicable, a copy of the postclosure 
plan. The closure and postclosure plans, which include groundwater monitoring requirements, are addressed in Section 2.4.13.

The federal protection requirements for regulated units are found at 40 CFR 270.14 (c). The requirements found at the federal level are nearly identical to the Washington State groundwater protection information requirements which must be included in a Part B application.

\subsubsection{Closure and Postclosure Care}

During closure and postclosure, the owner or operator of a regulated unit must continue to monitor the groundwater in accordance with the appropriate program set forth in the permit. A written closure plan is required and must be submitted along with the facility permit application and must be approved by the WDOE.

The closure plan must include a detailed description of groundwater monitoring activities that will be necessary to ensure that closure performance standards will be met. Dangerous waste disposal units are aiso required to have a written postclosure plan. This plan also must include a description of postclosure groundwater monitoring activities.

\subsection{RECENT REGULATORY CHANGES}

The regulations under RCRA are continuing to be revised. This section will discuss recent final and proposed rules. These changes in the federal regulations may be an indication of potential changes in the Washington State regutations.

\subsubsection{Einal Rules}

Effective January 11, 1988, EPA issued a new set of standards under Subpart X of 40 CFR 264 (52 FR 46946, December 10, 1987). These standards cover miscellaneous units and essentially complete the coverage of hazardous waste management units.

A miscellaneous unit is any hazardous waste management unit which is used to treat, store, or dispose of hazardous wastes but which does not fit the current definition of container, tank, surface impoundment, pile, land treatment unit, landfill; incinerator, boiter, industrial furnace; or under- 
ground injection wel1. With the promulgation of Subpart $X$, final RCRA permits can now be obtained for hazardous waste management units that use new technologies or modify existing technologies. On the Hanford Site, it will now be possible to obtain final permits for hazardous waste management units that use biological, chemical, and heat-treatment technologies.

Environmental performance standards, 40 CFR 264.601, provide guidance for the permit applicant. The existing quality of the groundwater, including other sources of contamination and their cumulative impact on the groundwater; the quantity and direction of groundwater flow; and the proximity to and withdrawa] rates of current and potential groundwater users must be considered when a permit is being issued.

The general facility corrective action requirements of 40 CFR 264.101 apply to miscellaneous units. The Subpart $F$ groundwater protection requirements for monitoring and response action programs apply only to those miscellaneous units that have potential to contaminate groundwater. These standards will apply on a case-by-case basis.

\subsubsection{Final Rule for Groundwater Monjtoring Requirements}

The EPA has amended the groundwater monitoring requirements of 40 CFR 264 (53 FR 39729, october 11, 1988). The changes in the regulations are focused upon revisions to the statistical procedures used to evaluate the presence of contaminants in the groundwater.

Several new definitions are included in the final rule. "Detection" is defined as statistically significant evidence of contamination as described in the revised statistical procedures at 40 CFR 264.98(f). Similarly, "exceeded" is defined as statistically significant evidence of increased contamination as described at 40 CFR 264.99(d).

\subsubsection{Final Changes to General Groundwater Monitoring Requirements}

Changes (53 FR 39729, October 11, 1988) to 40 CFR 264.97 include modifications to sampling frequency and the sampling evaluation procedure. The previous regulation required that groundwater quality be determined at least 
semiannually under a detection monitoring program and quarterly under a compliance monitoring program. The modifications of these requirements are summarized below.

For detection monitoring and where appropriate in compliance monitoring, a sequence of at least four samples must be taken to establish background. The sequence interval must ensure, as much as possible, that an independent sample is obtained. The uppermost aquifer's effective porosity, hydraulic conductivity, and fate and transport characteristics of the potential contaminants must be assessed [40 CFR $264.97(\mathrm{~g})(1)$ ]. An alternate sampling procedure may be used if approved by the EPA.

The previous statistical procedures for evaluating contamination at 40 CFR 264.97(4) were similar to WDOE's current requirements that are discussed in this document in Section 2.4.7. The new federal statistical requirements are given below:

- a parametric analysis of variance followed by multiple comparisons procedures to identify statistically significant evidence of contamination. The procedure must include estimation and testing of the contrasts between the mean level of each downgradient well and the mean level of each upgradient well for each constituent.

- an analysis of variance based on ranks, followed by multiple comparisons procedures to identify statistically significant evidence of contamination. The procedure must include estimation of the contrasts between the median level of each downgradient well and the background median levels for each constituent.

- a tolerance or prediction interval procedure in which a tolerance interval for each constituent is established from the distribution of the background data, and the level of each constituent in each downgradient well is compared with the upper tolerance or prediction level.

- a control chart approach that gives control limits for each constituent

- another statistical test procedure that is approved by the EPA. 
Any of the above statistical methods selected for specification in the unit permit must comply with the following performance standards:

- The statistical method used to evaluate groundwater monitoring data must be appropriate for the distribution of chemical parameters or hazardous constituents. If the distribution of the chemical parameters or hazardous constituents is shown by the owner or operator to be inappropriate for a normal theory test, then the data should be transformed or a distribution-free theory test should be used. If the distributions for the constituents differ, more than one statistical method may be needed.

- If an individual well comparison procedure is used to compare an individual compliance well constituent concentration with background constituent concentrations or a groundwater protection standard, the test must be done at a Type I error level no less than 0.01 for each testing period. If a muitiple comparisons procedure is used, the Type I experimentwise error rate for each testing period must be no less than 0.05 ; however, the Type 1 error of no less than 0.01 for individual well comparisons must be maintained. This performance standard does not apply to tolerance intervals, prediction intervals or control charts.

- If a control chart approach is used to evaluate groundwater monitoring data, the specific type of control chart and its associated parameter values must be proposed by the owner or operator and must be approved by the Regional Administrator if he or she finds it to be protective of human health and the environment.

- If a tolerance interval or prediction interval is used to evaluate groundwater monitoring data, the levels of confidence and, for tolerance intervals, the percentage of the population that the interval must contain, must be proposed by the owner or operator and approved by the Regional Administrator if he or she finds these parameters to be protective of human health and the environment. These parameters will be determined after considering the number of 
samples in the background database, the data distribution, and the range of the concentration values for each constituent of concern.

- The statisticai method must account for data below the 1imit of detection with one or more statistical procedures that are protective of human heaith and the environment. Any practical quantification limit (pql) approved by the Regional Administrator under 40 CFR 264.97(h) that is used in the statistical method must be the lowest concentration level that can be reliably achieved within specified limits of precision and accuracy during routine laboratory operating conditions that are available to the facility.

- If necessary, the statistical method must include procedures to control or correct for seasonal and spatial variability as well as temporal correlation in the data (53 FR 39729, October 11, 1988).

\subsubsection{Final Changes to the Detection Monitoring Program}

The requirements of the previous detection monitoring program at 40 CFR 264.98 were simitar to WDOE's current requirements (discussed in Section 2.4.8 of this document). In the new regulations, the EPA will specify the frequency for collecting samples and for conducting statistical tests to detect groundwater contamination. A sequence of at least four samples from each well (background and compliance wells) must be collected at least semiannual7y (53 FR 39729, October 11, 1988).

To determine if there is statistical evidence that contamination exists, the data collected at the compliance point are compared with background data using the seiected statistical method.

\subsubsection{Final Changes to the Compliance Monitoring Program}

The requirements of the previous compliance monitoring program at 40 CFR 264.99 were similar to WDOE's current requirements (discussed in Section 2.4.9 of this document). These requirements state that the groundwater must be sampled and tested at least quarterly. However, pursuant to recently revised federal regulations, the EPA has established the following sampling and testing frequencies: a sequence of at least four samples from each well (background and compliance wells) collected at least semiannualiy. 
Under the new rule (53 FR 39731, 0ctober 11, 1988), samples must be analyzed in accordance with the statistical procedures outlined for detection monitoring.

\subsubsection{Proposed Rule for Permit Modification for Hazardous Waste Management Facilities (52 FR 35838, September_23, 1987)}

On November 18, 1987, EPA amended the guidelines for permit modifications under 40 CFR 124, 264, and 270 (52 FR 41314). The EPA is proposing to categorize all permit modifications into three classes and to establish administrative procedures for approving modifications in each of these classes. For example, changes in the frequency of or procedures for monitoring or reporting may be a Class 1 or a Class 2 modification. Appendix I to 40 CFR 270.42 outlines the classifications of permit modifications. Part $C$ of Appendix I discusses groundwater protection and sets forth the eleven changes and their respective classes shown in Table 2.3.

For Class 1 modifications, WDOE must be notified within 7 calendar days after the change is put into effect. This notice must specify the changes being made to the permit or supporting documents referenced by the permit and must explain why the modifications are necessary. All persons on the facility's mailing list [see 40 CFR 124.10(c)(viii)] must be notified within 14 days. The WDOE must then inform the permittee by certified mait if a Class 1 modification is rejected (note: no time frames for the reply are given).

For Class 2 modifications, the permittee must submit a modification request to EPA. In addition, all persons on the facility mailing list must be notified, and the notice for permit modification must be published in a locat newspaper. A copy of the permit modification request and supporting documents must be placed in a location accessible to the public. A public meeting must be held no sooner than 15 days after publication of the notice and no less than 15 days before the close of the 60-day comment period. The 60-day comment period begins on the date the modification request is submitted to EPA. The EPA has 90 days to act on the modification request.

For Class 3 modifications, the permittee must submit a modification request and must publish a public notice (see discussion under Class 2 
TABLE 2.3. Classes of Groundwater Protection Permit Modifications Change

Class

1. Changes in hazardous constituents for which the groundwater protection standard applies

2. Changes in concentration limit (including $\mathrm{ACL}$ ) 3

3. Changes in point of compliance (e.g., due to inclusion of 2 other units in waste management area)

4. Changes to wells:

a. Changes in the number, location, or depth of upgradient or downgradient wells of permitted groundwater monitoring system

b. Replacement of an existing well that has been damaged or rendered inoperable, without change to location, design, or depth of the well

c. Replacement of existing wells resulting in a change to location, design, or depth of the well

monitoring schedule

6. Changes in established background groundwater quality concentration levels

7. Changes in statistical procedure for determining whether a statistically significant change in groundwater quality has occurred between upgradient and downgradient wells

8. Changes in parameters or constituents that the permit requires to be monitored

9. Addition of a compliance monitoring program as required by 40 CFR $264.98(h)(4)$ and 264.99 or changes to a compliance monitoring program as required by $264.99(\mathrm{k})$

10. Addition of a corrective action program as required by 264.99 (i) (2) and 264.100 or changes to a corrective action program as required by $264.100(\mathrm{~h})$

11. Reduction in number of hazardous constituents analyzed for assessment program based on no evidence of wastes in the unit 
modifications). A public meeting must be held no sooner than 15 days after the notice is published, and a second public meeting may be held if the permittee or a member of the public requests it. The people on the mailing list must be notified, and the notice must be published in a local newspaper. This notice includes the information required for the first public meeting. The public will have 60 days to comment before EPA grants or denies the request. Upon request of the permittee, the EPA may, without prior pub] ic notice and comment, grant the permittee a temporary authorization to operate under a modified permit for 90 to 180 days. 


\subsection{REGULATORY REQUIREMENTS FOR NONHAZARDOUS SOLID WASTE MANAGEMENT FACILITIES}

RCRA Subtitle D governs nonhazardous solid waste management. The EPA has not promulgated regulations regarding this area, but rather has left it to the states. Thus, this chapter reviews the implementing regulations (WAC 173-304) of Washington's Sol id Waste Management Act (RCW 70.95). These regulations apply only to facilities that manage nonhazardous solid waste.

\subsection{APPLICABILITY}

The Washington regulations for nonhazardous solid waste management facilities are applicable to facilities that handle nonhazardous "solid wastes" as defined in WAC 173-304-100(73):

"... all putrescible and nonputrescible solid and semisolid wastes, including but not limited to garbage, rubbish, ashes, industrial wastes, swill, demolition and construction wastes, abandoned vehicles or vehicle parts, and discarded commodities. This includes all liquid, solid, and semisolid materials which are not the primary products of public, private, industrial, commercial, mining, and agricultural operations. Solid wastes must be managed, stored, collected, transported, treated, utilized, processed, and disposed of in accordance with WAC 173-304."

\subsection{WAIVERS OR EXEMPTIONS}

The regulations for nonhazardous solid waste management facilities do not apply to the following solid wastes (WAC 173-304-015):

- overburden from mining operations intended for return to the mine

- liquid wastes whose discharge or potential discharge is regulated under federal, state or local water politution permits

- dangerous wastes as defined by RCW 70.105 and WAC 173-303 
- woodwaste used for ornamental purposes, animal bedding, mulch and plant bedding, or roadbuilding purposes

- agricultural wastes, limited to manures and crop residues, returned to the soils at agronomic rates

- clean soils and clean dredge spoils as defined in WAC 173-304-100 or as otherwise regulated by section 404 of the Federal Clean Water Act (Public Law 95-217)

- septage taken to a sewage treatment plant permitted under RCW 90.48

- radioactive wastes, defined by WAC 402-12 and -19

- wood debris resulting from the harvesting of timber whose disposal is permitted under RCW 76.04, the State Forest Practices Act.

\subsection{GENERAL REGULATORY REQUIREMENTS RELATING TO GROUNDWATER MONITORING}

Owners and operators of landfills, piles, landspreading disposal facilities, and surface impoundments, as appropriate, must abide by a plan of operation for groundwater monitoring. This plan must specify how and when inspections and monitoring are to be conducted and the corrective action measures that must be taken if groundwater becomes contaminated. Deviations from the pian of operation must be noted on the operating record. By March I of each year, an annual report must be submitted to WDOE. This report must include the results of groundwater monitoring. For disposal facilities, groundwater monitoring must continue through postciosure (WAC 173-304-405).

Specifically, regulatory requirements and exemptions for nonhazardous waste management units (i.e., waste piles, surface impoundments, energy recovery facilities and incinerators, landspreading disposal facilities, and landfi11s) are set forth in WAC 173-304-420 through -463. All of these sections require groundwater monitoring in accordance with WAC 173-304-490. Nonhazardous waste landfills have additional requirements relating to groundwater (WAC 173-304-461).

Groundwater underlying a landfill must not be contaminated beyond the point of compliance [WAC 173-304-461(2)(a)]. In this case, the point of compliance is that part of the groundwater lying beneath the perimeter of a 
solid waste facility's active area. "Contaminate" is defined as aliowing the discharge of a substance into the groundwater that would cause [WAC 173-304-100(16)]

- the concentration of that substance in the groundwater to exceed the state primary drinking water standards (see Chapter 5)

- a statistically significant increase in the concentration of a substance in the groundwater where the existing concentration of that substance exceeds state primary drinking water standards

- a statistically significant increase above background in the concentration of a substance that

- may not be specified in the state primary drinking water standards but is still of concern

- is not present in the solid waste

- has been determined by WDOE in consultation with the Washington Department of Social and Health Services (DSHS) to present a substantial risk to human health or the environment in the concentrations found at the point of compliance.

Analytical methods for determining the level of these contaminants may be found in 40 CFR 141. These leveis are to be considered interim levels for the purpose of regulating nonhazardous solid waste handing facilities and will be used only until WDOE establishes groundwater quality standards for all types of activities impacting groundwater.

Groundwater monitoring requirements (WAC 173-304-490) appiy to landfilis, piles, landspreading disposal facilities, and surface impoundments. The groundwater monitoring system must

- consist of at least one background or upgradient well and three downgradient wells, installed at appropriate locations and depths to yield groundwater sampies from the uppermost aquifer and al1 hydraulically connected aquifers below the active portion of the facility 
- represent the quality of background water that has not been affected by leakage from the active area

- represent the quality of groundwater passing the point of compliance

- include the statistical procedure for determining whether a significant change over background has occurred will be approved by WDOE.

Additional welis may be required by WDOE in a complex hydrogeological setting or to define the extent of contamination detected.

All monitoring wells must be cased in a manner that maintains the integrity of the monitoring weil boreholes. This casing must allow collection of representative groundwater samples. Wells must be constructed in accordance with WAC 173-360 and must prevent contamination of samples, of the sampled strata, and of the area between aquifers and water-bearing strata [WAC 173-304-490(2)(b)].

The groundwater monitoring program must include procedures and techniques for

- decontamination of drilling and sampling equipment

- sample collection

- sample preservation and shipment

- analytical procedures and quatity assurance

- chain of custody controt

- protection of employee health and safety during the installation and monitoring of wells [WAC 173-304-490(2)(c)].

\subsection{SAMPLE CONSTITUENTS}

Al1 facilities must test for

- temperature

- conductivity

- $\mathrm{pH}$ 
- chloride

- nitrate, nitrite, and annonia as nitrogen

- sulfate

- dissolved iron

- dissolved zinc and manganese

- chemical oxygen demand

- total organic carbon

- totar coliform [WAC 173-304-490(2)(d)].

The WDOE may specify additional or fewer constituents depending upon the nature of the waste. The groundwater surface elevation must also be determined each time the groundwater is sampled.

\subsection{REPORTING}

The groundwater quality at each monitoring well at the compliance point must be determined at least quarterly through the postclosure care period. The data must be expressed in a form that will allow the determination of statistically significant increases [WAC 173-304-490(g)]. If a statistically significant increase occurs for parameters or constituents at the monitoring well at the compliance point, the owner or operator must

- notify WDOE in writing within 7 days of receipt of the sampling data. The notification must indicate which parameters have shown statistically significant increases.

- immediately resample the groundwater in all monitoring weils and determine the concentration of atl constituents listed in the definition of contamination (i.e., WAC 173-304-9901 contaminant leveis) and whether there is a statistically significant increase such that the groundwater performance standard has been exceeded. The WDOE must be notified within 14 days of receipt of the sampling data [WAC 173-304-490(i)].

At least annualiy, the groundwater flow rate and direction in the uppermost aquifer must be reported [WAC 173-304-490(h)]. 



\subsection{COMPREHENSIVE ENVIRONMENTAL RESPONSE, COMPENSATION, AND LIABILITY ACT AS AMENOED BY SUPERFUND AMENDMENTS AND REAUTHORIZATION ACT OF_1986 AND THE EMERGENCY PLANNING AND COMMUNITY RIGHT-TO-KNOW ACT OF 1986}

The purpose of CERCLA is to provide for liability, compensation, cleanup, and emergency response for hazardous substances reieased into the environment and for the cleanup of inactive waste disposal sites. By enacting the Superfund Amendments and Reauthorization Act (SARA) in 1986, Congress reauthorized funding of the Superfund program and extensively amended CERCLA in a number of important respects, including the definition of cleanup standards. SARA also created the Emergency PIanning and Community Right-to-know Act of 1986 (EPCRA).

The focus of this chapter will be on the characterization and cleanup of inactive waste sites under CERCLA/SARA. The CERCLA/SARA reporting/ notification requirements for releases from facilities and the EPCRA emergency and comunity planning efforts will not be discussed.

The Hanford Site contains a number of inactive waste sites resulting from defense activities; DOE has performed preliminary assessments and site inspections and has met with the EPA to discuss the eligibility of these sites for the National Priorities List (NPL). On June 24, 1988, four areas $(100,200,300$, and 1100 Areas) of the Hanford Site were proposed for NPL listing (53 FR 23988, June 24, 1988). DOE has initiated the remedial investigations of some of these areas. Groundwater monitoring information will be very useful in preparing project plans, determining remedial action objectives, identifying potential applicable or relevant and appropriate requirements (ARARs), developing the site management strategy, and selecting the remedial a]ternatives.

CERCLA/SARA does not include prescriptive groundwater protection, monitoring, and reporting requirements; however, groundwater monitoring information is an integral component of site characterization. Groundwater monitoring information will be used to evaluate the extent of contamination and to understand the characteristics of the hydrology and geology underlying 
the individual inactive waste sites. In addition, monitoring wells will provide information on the quality and quantity of groundwater.

\subsection{INACTIVE WASTE SITES}

The identification of an inactive waste site may result in either a removal action or a remedial action. The distinction between these two actions is discussed below.

\subsubsection{Removal Action}

A removal action is generally a short-term, limited (by time, money, etc.) response to a problem; a removal action is more easily managed than a remedial action (see Section 4.1.2). For example, a removal action might mean cleaning up all the liquid and the contaminated soil resulting from a spill (for disposal elsewhere), leaving no contamination on the surface.

The first step in a removal action is a preliminary assessment. This assessment is based on information and data collected on the site. Presumably, groundwater monitoring data are required to adequately evaluate the extent to which the site has been contaminated and to determine the appropriateness of a removal action.

Depending on the results of monitoring and other evaluations, a removal action may or may not be required. Once that determination has been made and the removal action, if required, has been completed, the process shifts to determining whether a remedial action is required.

\subsubsection{Remedial Action}

A remedial action is a response that attempts to minimize the release of hazardous substances by preventing migration (through the use of underground barriers, diversions, revegetation, etc.). An example of a remediat action would be a program designed to decontaminate soils and sediments and to clean up the underlying groundwater. Such action could also involve the emplacement of subsurface barriers to prevent migration of hazardous substances. A removal action and a remedial action can occur separately and uniquely; however, they may also occur together if, for example, a removal action is necessary to facilitate a remedial action. Both of these actions are preceded 
by an assessment or evaluation to determine the nature and extent of any releases and/or potential threats to public health and welfare and the environment.

The remedial action itself is the endpoint of a process that includes a preliminary assessment/site inspection (PA/SI) phase, followed by a remedial investigation/feasibility study (RI/FS) phase, followed by a Record of Decision (ROD), and culminating in a remedial design/remedial action ( $R D / R A)$ phase. The ROD is the process EPA uses to select an appropriate clean-up option from severa] alternatives examined during the RI/FS. Depending on the extent of contamination and/or the effectiveness of the selected remedy, an operation and maintenance (O\&M) phase will most likely be necessary after the renedial action is started.

On July 14, 1988, the Hanford Site was nominated for 1 isting on CERCLA's Nationa1 Priority List (NPL) (53 FR 23988). Groundwater monitoring information was used in the PA/SI phase to support this nomination.

Groundwater monitoring information will also be useful during the RI/FS phase [40 CFR 300.68(d), (e), and (k)]. Under 40 CFR 300.68(d), "Remedia] Investigation/Feasibility Study":

"An RI/FS shal1, as appropriate, be undertaken by the lead agency conducting the remedial action to determine the nature and extent of the threat presented by the release and to evaluate the proposed remedies. This includes sampling, monitoring, and exposure assessment, as necessary, and includes the gathering of sufficient information to determine the necessity for and proposed extent of remedial action."

The groundwater assessment requirements 1 isted under 40 CFR $300.68(e)(2)$, "Scoping of Response Actions During the Remedial Investigations," are described below:

"the following shall, as appropriate, be assessed in determining whether and what type of remedial and/or removal actions will be 
considered: ... (iv) hydrogeological factors (e.g., soil permeability, depth to saturated zone, hydrologic gradients, proximity to a drinking water aquifer, floodplains and wetlands proximity); (v) current and potential groundwater use (e.g., the appropriate groundwater classes under the system established in the EPA Ground-Water Protection Strategy); (xi) the extent to which the substances have migrated or are expected to migrate from the area of their original location...; ( $x i$ i) the extent to which Federal environmental and public health requirements are applicable or relevant and appropriate to the specific site, and the extent to which other Federal criteria, advisories, and guidance and State standards are to be considered in developing the remedy; (xiii) the extent to which contamination levels exceed applicable or relevant and appropriate Federal requirements or other Federal criteria, advisories, and guidance and State standards; ..."

The regulations at 40 CFR $300.68(k)$, "Remedial Site Sampling, " require a quality assurance site sampling plan. This plan must include, among other things

- "Sufficient sampling to adequately characterize the source of the release, likely transport pathways, and/or potential receptor exposure;

- Specifications of the types, locations, and frequency of samples taken, taking into account the unique properties of the site, including the appropriate hydrological, geological, hydrogeotogical, physiological, and meteorological properties of the site; and

- Such other elements as may be required by the remedial project Manager (RPM) and the appropriate EPA Regional Headquarters quality assurance office on a site-by-site basis."

The 08M phase of a remedial action can last up to ten years (Arbuckle et al. 1987). In the case of ground or surface water contamination, the action inciudes the completion of treatment or other measures necessary to 
restore ground and surface water quality to a level that assures protection of human health and the enviromment [CERCLA Section 104(c)(6)].

A remedial action (or the end-result of a remedial action) must comply with requirements or standards under federal and state environmental laws which assure that the cleanup of a site protects human health and the environment. CERCLA Section $121(d)(2)(A)$ states:

"... the remedial action selected under 104 or secured under section 106 shall require, at the completion of the remedial action, a level or standard of control for such hazardous substance or pollutant or contaminant which at least attains such legally applicable or relevant and appropriate standard, requirement, criteria, or limitation. Such remedial action shall require a level or standard of control which at least attains maximum contaminant Tevel goals (MCLGS) established under the Safe Drinking Water Act (SDWA) and water quality criteria established under Section 303 or 304 of the Clean Water Act, where such goals or criteria are relevant and appropriate under the circumstances of the release or threatened release."

The regulations [40 CFR 300.68 (i)] state that the selection of a remedy will "attain or exceed applicable or relevant and appropriate federal public health and environmental requirements that have been identified for the specific site." If there are no applicable or relevant and appropriate federal public health or environmental requirements (including requirements for groundwater protection), the cost, technology and reliability of an alternative will be considered in selecting a remedy that effectively mitigates and minimizes threats to and provides adequate protection of public health and welfare and the environment. Other federal criteria, advisories, and guidance and state standards (such as EPA's Groundwater Protection Strategy) will also be considered and used in developing alternatives, with adjustments for site-specific circumstances.

EPA's Interim Guidance on Compliance with Applicable or Relevant and Appropriate Requirements (OSWER 9234.0-05) provides guidance on clean-up requirements that may be applicable or relevant and appropriate to a CERCLA 
site. The guidance document describes a classification of ARARs with the heading "Ambient or Chemical-Specific Requirements," which contains examples such as maximum contaminant leveis (MCLS - from the Safe Drinking Water Act program) and National Ambient Air Quality Standards (from the Clean Air Act program). Since groundwater monitoring will most 1 ikely be an integral part of site characterization and clean-up activities, the groundwater protection programs should be developed with the CERCLA/SARA ARARs and other remedial action considerations in mind. 


\subsection{SAFE DRINKING WATER ACT}

A comprehensive review of the drinking water monitoring and reporting requirements is provided in this document because of the continuing use of wells as sources of drinking water at several Hanford Site facilities. In addition, standards for protecting drinking water supplies may be used as relevant technical standards to ensure that groundwater protection is appropriateiy considered. Drinking water standards may also be used as CERCLA clean-up standards. Relevant strategies, polices, and guidelines such as those developed under SDWA's wellhead protection program, sole source aquifer program, and EPA's groundwater classification guidelines were al so reviewed because they may be used to develop a comprehensive groundwater protection program.

Drinking water requirements designed to protect public health are derived from the Safe Drinking Water Act (SDWA), as amended, and appear in EPA's SOWA regulations. Various sections of the SOWA, including public water systems (Part $B$ ), protection of underground sources of drinking water (Part C), and general provisions (Part E), are all considered in the following paragraphs. The particular implementing regulations that originate from these sections of SWDA and that are reviewed below are

- National Primary Drinking Water Regulations (NPDWR) (40 CFR 141)

- National Interim Primary Drinking Water Regulations Implementation (40 CFR 142)

- National Secondary Drinking Water Standards (40 CFR 143)

- Underground Injection Control (UIC) Program (40 CFR 144)

- State UIC Program Requirements (40 CFR 145)

- UIC Program: Criteria and Standards (40 CFR 146)

- State UIC Programs (40 CFR 147)

- Proposed regulations to the Hazardous Waste Injection Restrictions (40 CFR 148)

- Interim final rule for Sole Source Aquifers (40 CFR 149). 
Washington has adopted a statute and promulgated regulations to implement drinking water standards (RCW 43.20 and WAC 248-54), to administer and enforce the UIC program (RCW 43.21A.445 and WAC 173-218), and to participate in any future funding of the sole source aquifer protection program ( $R C W$ 43.21A.445). Because Washington has been authorized by EPA to administer and enforce the public water supply system and the UIC program regulations set forth under the SDWA, this review will focus upon state regulations relevant to these two areas.

This chapter is divided into sections on the public water systems program, the UIC program, EPA's groundwater classification guidelines, and the sole source aquifer and wellhead protection area programs. This review will focus primarily upon the primary and secondary drinking water standards under the public water systems program.

(The DOE-RL Order 4330.2 applies to potable water supplies at Hanford; see Chapter 8.0 of this report.)

\subsection{PUBLIC WATER SYSTEMS}

Part B of the SDWA [42 USC $300(\mathrm{~g})$ ] applies to public water systems that use surface water and groundwater. It authorizes the development of primary and secondary drinking water regulations. A public water system is defined in Part $A$ as

"... a system for the provision to the public of piped water for human consumption, if such system has at least fifteen service connections or regularly serves at least twenty-five individuals. Such term includes (A) any collection, treatment, storage, and distribution facilities under the control of the operator of such system and used primarily in connection with such system, and (B) any collection or pretreatment storage facilities not under such control which are used primarily in connection with such system." [42 USC $300(f)$ ]

The DSHS, which is the state agency with authority to regulate public water supplies (including surface water and groundwater) in Washington, has defined "public water systems" as: "Any water supply system intended or used 
for human consumption or other domestic uses, including source, treatment, storage, transmission, and distribution facilities where water is furnished to any community or group of individuals, or is made available to the public for human consumption or domestic use, but excluding all water supply systems serving one single family residence" [WAC 248-54-015(19)].

It is important to note that DSHS's definition is broader than EPA's in that no lower limit for individuals is specified. All water distribution systems on the Hanford Site are encompassed by the DSHS definition of pubiic water systems.

\subsubsection{Public Water System Classifications}

Under the federal regulations (40 CFR 141), public water systems are divided into three classes:

- a community water system, which serves at least 15 service connections used by year-round residents or regularly serves at least 25 year-round residents

- a noncommunity water system, which is a pubtic water system that is not a community water system

- nontransient, noncomunity water system, which serves at least 25 of the same people for more than 6 months out of the year.

Separate federal standards are provided for community and noncomunity water systems. The state does not make any distinction between the applicability of prescribed standards to particular classes of systems; all public water supply systems must meet the standards in WAC 248-52.

The state definition of a public water system varies from the federat. It excludes from certain standards only water systems that serve one, singlefamily residence. The state distinguishes between different classes of public water systems based on the number of service connections and people served and whether the population is permanent or transitory. Under the

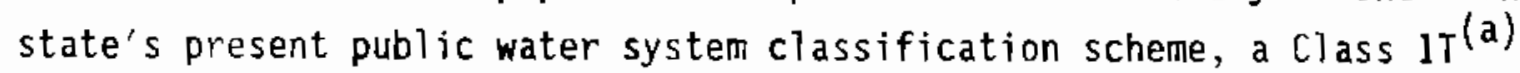
water supply system is defined as a system that serves more than 1000 people

(a) The "T" designates the transitory population. 
on any one day; a Class $2 \mathrm{~T}$ serves 300 -999 people on any one day; a Class $3 \mathrm{~T}$ serves 25-299 people on any one day; and a Class $4 \mathrm{~T}$ serves fewer than 25 people on any one day [WAC 248-54-015(2)].

As public water systems, the Hanford Site water systems are evaluated for compliance with federal and state regulatory requirements for public water supply systems. As of 1985, there were 4 individual drinking water systems on the Hanford site that use groundwater (Somers 1986). These systems ranged in size from those which routinely served transitory populations of more than 200 people (e.g., 400 East Area) to those which served less than 25 (e.g., PNL Observatory). There are 14 other drinking water systems on the Hanford Site (all of which comply with the SDWA); however, these systems use the Columbia River (a surface water) as a source of drinking water. These 14 systems are not considered here because this report focuses on groundwater.

\subsubsection{Primary and Secondary Drinking Water Standards}

Drinking water standards are generally established under the SDWA and adopted and enforced by the states. The primary purpose of these standards is to protect the health of consumers using public drinking water supplies. If any public water system is out of compliance, the DSHS may initiate appropriate actions. These actions may include issuance of letters requiring appropriate corrective actions and schedules for specific actions necessary to achieve compliance (WAC 248-54-045).

Standards for drinking water may be used as ARARs for CERCLA remedial actions to clean up groundwaters (see Chapter 4). In addition, future federal and state regulations may use drinking water standards for aquifer protection. Although drinking water standards are only strictly applicable to public drinking water supplies, they may be used as guidance for a groundwater monitoring program.

The primary drinking water standards are set at two levels for each contaminant: a maximum contaminant level goal (MCLG), which is the level at which one may assume with a margin of safety that no adverse health-based effects would arise; and an MCL, which sets enforceable limits as close to the MCLG as is feasible, taking into account cost, laboratory capability, and other factors. 
Existing state and federal MCLs and MCLGs, as well as monitoring, corrective action, and reporting regulations associated with a particular category of drinking water contaminants, are presented in Tables 5.1 through 5.10.(a) These categories of contaminants (based on the categories defined by state regulations) include bacteria, inorganic chemical and physical contaminants, trihalomethanes, pesticides, and radionuclides; in addition, the turbidity and corrosivity of the water must meet certain standards (WAC 248-54). Proposed changes to the existing federal and state regulations are also noted in the tables. In addition, the 1986 SDWA amendments directed the EPA to publish MCLGs and promulgate national primary drinking water standards for 83 new contaminants within 3 years from the date of enactment [SDWA Section 1412(b)(1)]. The 1986 amendments also required EPA to establish the "drinking water priority list" (DWPL) by January 1, 1988, and to publish MCLGs and promulgate primary drinking water regulations for at least 25 of the contaminants on the DWPL by January 1, 1991 [Section 1412(b)(3)].

The 83 contaminants that EPA must regulate under the 1986 amendments are found in Table 5.1. National primary drinking water regulations and MCLGs were required to be promulgated for at least 40 of the 83 contaminants by June 19, 1988 [Section 1412(b)(1)(B)]; however, EPA has not published these yet. The EPA's current target date for finalization of these regulations is March 1989. (b) The standards for the 83 contaminants have been and are being developed as follows:

- Eight new standards for volatile organic chemicals were promulgated in 1987 (see Table 5.9).

- Forty new and revised standards will be promulgated in 1989, including 10 for inorganics and 30 for synthetic organics.

- Standards for other volatile and synthetic organics on the original list will be promulgated in late 1989.

(a) To avoid disrupting text, the tabies are presented at the end of this chapter.

(b) Telephone conversation between Richard R. Thiel (EPA) and A. J. Schmidt (PNL), June 16, 1988. 
- Radionuclides, including new standards for radon and uranium, and revisions to existing radium standards will be promulgated in late 1989.

- Disinfection and disinfectant by-products standards including mandatory disinfection standards for all systems will be promulgated in late 1990 (Reeverts, December 1987).

On January 22, 1988, 53 contaminants were placed on the first DWPL; these are shown in Table 5.2. The DWPL will be revised every 3 years and will serve as the mechanism by which EPA considers contaminants for future regulation. Regulations must be promulgated by EPA for 25 contaminants on the DWPL every 3 years (53 FR 1987, January 22, 1988). The secondary drinking water regulations specify secondary maximum contaminant levels (SMCLS) for contaminants that may adversely affect the odor or appearance of the water. The SMCLs serve as guidelines to the states and are not enforceable.

The primary and secondary drinking water MCLs are equally applicable to a11 water system classes under the state regulations. However, the frequency of monitoring and the degree of compliance required by the state will vary depending upon the number of people served by the system and whether or not specific Hanford Site water supply systems are supplied by a surface or groundwater source.

\subsubsection{Bacteriological Content}

This subsection will present current and proposed regulations for bacteria count in drinking water.

\section{Federal Regulations}

The current federal MCLs for coliform bacteria are set forth at 40 CFR 141.14. Standards for two coliform measurement techniques (membrane filter and filtration tube) are described in detail. The minimum number of samples which must be tested per month for coliform contamination is based upon the 
population served by water supply systems. The table which provides the required testing frequencies is found at 40 CFR 141.21.

\section{Federal Proposed Regulations}

On November 13, 1985, recommended MCLs (now called MCLGs) of zero were proposed at 40 CFR 141.52 for total coliforms, Giardia, and viruses (50 FR 46936). In response to the 1986 SDWA amendments, regulatory amendments which address monitoring and analysis requirements for total coliforms also included a revised MCL and reproposed the MCLG of zero. In addition, if the proposed rule is finalized, the current $\mathrm{MCL}$ coliform requirement will be deleted and a limit will be set for heterotrophic bacteria. On May 6, 1988, a notice was issued to close the public comment period for the proposed total coliform rule on Ju7y 5, 1988 (52 FR 16348). The closure of the public comment period is an indication that the final action of the proposed rule may be forthcoming.

A new subpart $H$ that addresses filtration and disinfection is proposed for 40 CFR 141 (40 CFR 141.70) (see 52 FR 42178). These requirements constitute NPDWRs that establish criteria under which filtration is required as a treatment technique for public water systems supplied by surface water sources or groundwater sources that are subject to surface water impacts. These regulations also establish treatment techniques in lieu of MCLs for the following categories: Giardia lamblia, viruses, heterotrophic plate count bacteria, Legionellae, and turbidity. Acceptable treatment for these contaminants is proposed at 40 CFR 141.70 to 141.76 (52 FR 42178).

\section{State Requlations}

The recently revised public water supplies regulation (WAC 248-54) became effective March 18, 1988 (WSR 88-05-057). MCLs, MCLGs, monitoring frequencies, and follow-up actions from these regulations are provided in Tables 5.3 and 5.4 .

The required bacteriological sampling frequencies for water distribution systems based on permanent services (Class 1 and 2 systems) are found in Table 1 of WAC 248-54-165. The sampling requirements for transitory population systems (Class 3) are based upon the maximum number of people served by 
a system in any one month. The minimum number of routine samples that must be analyzed for Class 3 systems is listed in Table 5.4 (as taken from Table 2 of WAC 248-54-165). Because the population at the Hanford Site is transitory, the Class 3 water systems monjtoring frequencies are applicable to Hanford Site water systems.

\subsubsection{Inorganic Chemical and Physical Contaminants}

Primary and secondary standards for inorganic chemicals and physical contaminants are presented in Table 5.5. Most of the inorganic chemicals for which MCLs and SMCLs have been estabilished at both the state and federal level are heavy metals. Several changes to the $M C L$ and $S M C L$ listings for inorganic chemical and physical contaminants were made in the revised state regulations (WAC 248-54). Genera11y, SMCLs are not enforceable; however, SMCLs are now subject to enforcement at the discretion of the DSHS (WAC 24854-175). The new primary MCL and SMCL for fluoride are $4.0 \mathrm{mg} / \mathrm{L}$ and $2.0 \mathrm{mg} / \mathrm{L}$, respectively. Before March 18, 1988, the $\mathrm{MCL}$ for fluoride was $2.0 \mathrm{mg} / \mathrm{L}$. An additional change in the state regulations is that hardness is now included as a physical characteristic; however, no secondary MCL has been provided for this new parameter. The federal MCL and SMCL for fluoride are identical to those established by the state. The federal regulations have a) so established a MCLG of $4.0 \mathrm{mg} / \mathrm{L}$ for fluoride (40 CFR 141.51).

On August 27, 1980, the EPA recommended a sodium Timit for drinking water of $20 \mathrm{mg} / \mathrm{L}$ (45 FR 57332). Sodium was included on the list of $83 \mathrm{con}$ taminants to be regulated; however, on January 22, 1988, (53 FR 1892) it was removed because drinking water is not the primary dietary source of sodium for most people. Nevertheless, the state has maintained a drinking water monitoring requirement for sodium, but has not established an MCL or an SMCL in the revised regulations.

The revised state regulations have reduced the turbidity monitoring requirement from continuous monitoring to a minimum standard of one turbidity reading per day [WAC 248-54-165(4)]. Turbidity monitoring is required at or 
before the entry point to the distribution system and where needed for treatment process control. The federal regulations also require at least one turbidity determination per day (40 CFR 141.22).

\subsubsection{Corrosivity}

Unless otherwise required by DSHS, corrosivity monitoring at the state level is required for Class 1 and 2 water systems only [WAC 248-54-165(6)]. Samples from surface water systems must be taken and analyzed twice in a 12-month period, while groundwater sources require onty one corrosivity analysis in a 12-month period, as shown in Table 5.6. After the results of the initial anaiyses have been obtained, corrosivity monitoring requirements will be specified by DSHS. Because corrosivity has only a secondary contaminant standard, the federal leve 1 has no required monitoring frequencies. However, at 40 CFR 143.4, it is recommended that corrosivity, and all other secondary contaminants, should be monitored at least as often as primary inorganic contaminants.

\subsubsection{Pesticides}

Pesticide monitoring requirements are limited to sampling $\mathrm{Class} 1$ and 2 surface water systems, unless otherwise directed by DSHS. The monitoring frequency for such systems is set at one analysis every 36 months [WAC 248-54-165(7)]. Pesticide MCLs and follow-up actions that are required if an MCL is exceeded are presented in Table 5.7.

\subsubsection{Trihalomethanes}

Total trihalomethanes (the sum of the concentrations of bromodichloromethane, dibromochloromethane, tribromomethane, and trichloromethane) must not exceed $0.10 \mathrm{mg} / \mathrm{L}$ in drinking water systems in both the state (WAC 248-54-175) and the federal (40 CFR 141.12) regulations (see Table 5.8). Untess otherwise required by the DSHS, state regulations require monitoring for trihalomethane only for $\mathrm{Cl}$ ass $\mathrm{l}$ systems that serve a population of at least 10,000 people and that use chlorine or another oxidant within the treatment process. 
Hanford Site drinking water sources have been sampled and tested for trihalomethanes. Compliance with the applicable MCL for total trihalomethane has been continually demonstrated for Hanford Site systems. (a)

\subsubsection{Standards for Other Organics}

The NPDWPS (40 CFR 141) that will become effective on January 9, 1989, were amended to inciude MCLS and MCLGs for 8 volatile organic chemicals (VOCs) and monitoring requirements for 51 unregulated synthetic organic chemicals (52 FR 25690, july 8, 1987). On July 1, 1988, minor corrections were made to these amendments to clarify some of the new provisions (523 FR 25108). The newly revised public water supplies regulations (WAC 248-54) do not include specific regulations for any voCs. However, the new state regulations include a category referred to as "other organics," and WAC 248-54-165(9) and (10) include provisions for monitoring "as directed" by DSHS for both organic compounds with and without established MCLs.

The relevant monitoring schedules and notification procedures for the organic chemicals addressed in the adopted federal amendments are included in Table 5.9. Chemicals for which monitoring is required at the state's discretion are also listed in this table. Beginning January 1, 1989, Hanford Site water systems will be required to monitor the eight vocs listed in Table 5.10.

The Hanford Environmental Health Foundation (HEHF) has collected some data on the 8 VOCs and 6 of the 51 unregulated chemicals, in anticipation of beginning compliance monitoring for both groups of chemicals in the first quarter of $\mathrm{CY}$ 1988. (a) Preliminary data results indicated that the eight regulated VOCs were well below the MCLs in all Hanford systems.

\section{1 .9 Radionuclides}

The standards for the radionuclides which are presented in Table 5.10 are found at WAC 248-54-175 and 40 CFR 141.15 and 141.16. Specifically included in Table 5.10 are naturally occurring radionuclides, radionuclides

(a) Letter from L. Maas to M. W. Tiernan, August 5, 1987. 
with gross alpha particle activity, manmade radioactivity, and radium. The MCLs for radionuclides have been set in both federal and state regulations.

Radiological data results on Hanford samples collected in the 400 Area during $C Y 1985$ showed an annual average tritium concentration in excess of the $10,000 \mathrm{pCi} / \mathrm{L}$ screening leve1 (Somers 1986). Dose calculations performed using CY 1985 data showed a 50-year dose commitment of 0.34 mrem received from drinking the water at the 400 Area (Somers 1986).

\subsection{UNDERGROUND INJECTION CONTROL PROGRAM}

Part $C$ of the Safe Drinking Water Act [42 USC 300(h)] sets forth the basis for promulgating regulations that limit the underground injection of materials into or near sources of potential underground sources of drinking water (USDWs). As defined in the statute, underground injection means the subsurface emplacement of fluids by well injection. The statute further specifies that, "underground injection endangers drinking water sources if such injection may result in the presence of contaminants in underground water which supplies or can reasonably be expected to supply any public water system of any contaminant, and if the presence of such contaminant may result in such systems not complying with any National Primary Drinking Water Regulation or may otherwise adversely affect the health of persons."

\subsubsection{Injection Well Classification}

The implementing regulations for the UIC program at the federal and state levels are set forth in 40 CFR $144-147$ and WAC 173-218, respectively. The WDOE has been authorized to administer the UIC program in Washington for five classes of injection wells.

These 5 types of wells are as follows:

- Class I: deep injection wells

- Class II: oil, natural gas, and liquid hydrocarbon wells

- Class III: mining wells

- Class IV: radioactive (above Table 2 of 10 CFR 20, Appendix B) and hazardous waste wells 
- Class V: other wells.

Hanford has submitted a registration for Class $V$ underground injection wells. Class I-IV injection wells are not applicable to waste disposal at Hanford.

The WDOE will accept, process, and act upon the application in accordance with the procedures and practices of the state regulations. Individual permits will be issued at WDOE's discretion.

If WDOE issues a permit for the operation of any injection well, the permit will specify "conditions necessary to prevent and control injection of fluids into waters of the state" [WAC 173-218-100(1)]. The specified "conditions" will most likely contain groundwater monitoring requirements and will include the following, whenever applicable: 1) all known, available, and reasonable methods of prevention, control, and treatment; 2) applicable requirements as contained in 40 CFR 124, 144, and 146; and 3) any conditions necessary to preserve and protect a USDW.

Although the Hanford Site does not use Class I injection wells, a brief discussion is included here because these monitoring activities may be used in developing groundwater protection programs.

The state of Washington requires that the monitoring and compliance requirements for permitted Class I injection wells specified in 40 CFR 144 and 146 be applied (WAC 173-218-050). Current monitoring and reporting requirements for aII UIC permits are set forth in 40 CFR 144.51. These requirements include

1. Samples and measurements taken for the purpose of monitoring must be representative of the monitored activity.

2. The permittee must retain records of all the monitoring information (for a period of at least three years from the date of the sample, measurement, report or application) including calibration and majntenance records, original strip chart recordings for continuous monitoring instrumentation, copies of all reports required by the permit, and records of all data used to apply for the permit 
3. Records of monitoring information must include

- date, exact place, and time of sampling or measurements

- individual(s) who performed sampling or measurements

- date(s) analyses were performed

- individual(s) who performed analyses

- analytical techniques or methods used

- results of such analyses.

4. Monitoring results must be reported at the intervals specified in the permit.

Within 24 hours the permittee must orally report to WDOE any noncompliance with the permit conditions that may endanger health or the environment. Such conditions include any monitoring or other information which indicates that any contaminant may endanger a USDW, or any noncompliance with a permit condition or malfunction of the injection system that may cause fluid migration into or between USDWs. A written submission must be provided within 5 days of the time the permittee becomes aware of the circumstances. The written submission must include a description of the noncompliance and its cause; the period of noncompliance (exact dates and times); and steps taken or planned to reduce, eliminate, and prevent a recurrence.

Section 1426 of the SDWA required that Class I weIl monitoring methods be identified within 18 months after enactment of the SDWA Amendments of 1986. Thus, proposed monitoring requirements specific to Class I wells were issued for comment in August 1987 (52 FR 32446, August 27, 1987). The proposed 40 CFR 146.13 requirements would satisfy the mandate of section 1426 of the SDWA by requiring the owners or operators of all Class I wells to develop an ambient monitoring program. Annual monitoring of pressure buildup in the injection zone would be required. Such monitoring would include, at a minimum, a shutdown of the well for a time sufficient to conduct a valid observation of the pressure fall-off curve. The proposed requirements further stipulate that any of the following additional monitoring may be required at the discretion of the WDOE: 
- continuous monitoring for pressure changes in the first aquifer overlying the confining zone. When such a well is installed, the owner or operator must sample the aquifer on a quarterly basis and must analyze constituents specified by the authorized representative.

- the use of indirect geophysical techniques to determine the position of the waste front, the water quality in a formation designated by the WDOE, or other site-specific data

- periodic monitoring of the groundwater quality in the first aquifer overlying the injection zone

- periodic monitoring of the groundwater quality in the lowermost USDW

- any additional monitoring necessary to protect USDWs.

Criteria and standards applicable to Class I hazardous waste injection wells have also been proposed in 52 FR 32467 (August 27, 1987) as a new Subpart G addition to 40 CFR 146 . The criteria and standards include requirements concerning corrective action for wells in the area of review (40 CFR 146.64); construction (40 CFR 146.65); operation (40 CFR 146.67); testing and monitoring (includes proposed ambient monitoring (described previous7y) [40 CFR 146.13)] (40 CFR 146.68); reporting (40 CFR 146.69); information to be evaluated by the authorized representative in authorizing $C l$ ass I hazardous waste wells (40 CFR 146.70); closure (40 CFR 146.71); and postclosure care (40 CFR 146.72).

Hazardous waste injection restrictions (a new 40 CFR 148) have also been proposed (52 FR 32474, August 27, 1987). This part identifies and 1ists hazardous wastes that are restricted from disposal into Class I hazardous waste injection wells and also establishes provisions under which a waste otherwise prohibited from injection may be injected.

\subsubsection{Exemptions for Underground Injection Control Wells}

The state of Washington considers all groundwater which contain less than $10,000 \mathrm{mg} / \mathrm{L}$ of total dissolved solids or which is obtainable for beneficial use to be an underground source of drinking water (USDW) 
[WAC 173-218-030(16)]. However, the federal definition for USDW oniy includes aquifers or portions of aquifers which suppiy public water systems, or which have the potential to supply a public water system and currently supply drinking water for human consumption (40 CFR 744.3). Un7ike the state, the federal regulations include provisions by which aquifers can be exempted from certain underground injection control requirements (40 CFR 144.7). Aquifers which are not exempted, and which do not meet the criteria for USDWs, do not receive USDW protection [40 CFR 144.2(g)]. Current discussions between DOE and the regulatory agencies should establish jurisdictional protocol for the Hanford Site groundwater.

\subsection{ENVIRONMENTAL PROTECTION AGENCY GUIDELINES FOR GROUNOWATER}

\section{CLASSIFICATION}

In 1984 EPA released its groundwater protection strategy, and in December 1986, EPA issued the final draft of "Guidelines for Ground-Water Classifications under EPA Ground-Water Protection Strategy, " based on the strategy developed earlier. The purpose of the 400-page draft guideline document is to define classes of groundwater and to describe procedures for classifying groundwater within a prescribed area around a facility or activity. Three general classifications which serve as the foundation of the proposed hierarchical groundwater protection policy are based upon the value, use, and vulnerability of potentially affected groundwater. Descriptions of these classification systems, which will be afforded different levels of protection, are provided beiow (EPA 1986):

- Class I - Special Groundwaters

- Class I groundwaters are resources of unusually high value. They are highly vulnerable to contamination and are 1) irreplaceable sources of drinking water and/or 2) ecological7y vital. Groundwater that is highly vulnerable to contamination is characterized by a relatively high potential for contaminants to enter and/or to be transported within the groundwater system. 
- Class 11 - Current and Potential Sources of Drinking Water and Water Having Other Beneficia? Uses

- Al1 non-Class I groundwater currently used or potentially available for drinking water and other beneficial use is included in this category, whether or not it is particularly vulnerable to contamination. This class is divided into two subclasses: current sources of drinking water (Subclass IIA) and potential sources of drinking water (Subclass IIB).

- Class III - Groundwater Not a Potential Source of Drinking Water and of Limited Beneficial Use

- Groundwaters that are saline or otherwise contaminated beyond levels which would allow use for drinking or other beneficial purposes are in this class. They include groundwaters that 1) have a total-dissolved-solids (TDS) concentration over $10,000 \mathrm{mg} / \mathrm{L}$, or 2) are so contaminated by naturally occurring conditions or by the effects of broad-scale human activity (i.e., unrelated to a specific activity) that they cannot be cleaned up using treatment methods reasonably employed in public water supply systems.

The proposed guidelines, if implemented, would establish a procedure for classifying groundwater by site, rather than by region or aquifer. A "classification review area" would be established within a 2 -mile radius of the boundary of any facility that may affect groundwater. The review area could be expanded for sites with higher groundwater flow velocities. Within the classification review area, data must be accumulated as necessary to properiy classify the groundwater. Generally, it will be assumed that the groundwater within the review area is connected hydrogeologically. However, if hydrogeological knowledge is available, then the classification review area could be subdivided to more accurately classify the groundwater.

This groundwater classification system may become a factor in determining the level of protection or remediation to be applied to CERCLA. The EPA 
has estimated that 83 to 94 percent of groundwater classification determinations under the proposed guidelines would result in Class II designations and would be subject to drinking water standards. Sites that are located in areas protected under the Sole Source Aquifer Program (see Section 8.5) will not necessarily be placed in Class I, since the Class I criteria are more stringent (EPA 1987).

\subsection{SOLE SOURCE AQUIFER PROGRAM}

Section 1424(e) of the SOWA describes the process for designating a sole source aquifer. This section of the SDWA was written to prevent federally assisted projects from contaminating those aquifers that are the sole or principal source of drinking water for an area. Though no groundwater standards or monitoring requirements have been promulgated, criteria for identifying critical aquifer protection areas within designated sole source aquifer areas have been issued as an interim final rule (52 FR 23982, June 26, 1987).

\subsection{WELLHEAD PROTECTION AREA PROGRAM}

A wellhead protection area is the surface and subsurface area surrounding a water well or wellfield supplying a public water system which contaminants are reasonably likely to move toward and reach. Section 1428 of the SDWA gives states the authority to establish wellhead protection programs by 1989. The purpose of the programs is to identify wellhead protection areas and all potential sources of contaminants in those areas that may adversely affect the health of humans. The programs are to develop means by which water supplies within wellhead protection areas are protected from contamination. The programs are also to establish a requirement that consideration be given to al1 potential sources of contamination within the expected wellhead area of a new water well that serves a public water supply system.

In accordance with provisions of the SDWA, EPA has recentiy issued technical guidance to the states to aid them in determining the extent of 
wet Thead protection areas (EPA 1987). The guidance includes criteria for establishing a "classification review area" that is delineated within a 2-mile radius from the boundaries of an "activity" affecting groundwater, etc. 
IABLE 5.1. Contaminants Required to be Regulated under SDWA 1986 Amendments (53 FR 1892, January 22, 1988)

Volatile Organic Chemicols

Trichloroethylene Tetrachloroethylene

Carbon tetrachloride

1,1,1-Trichloroethane

$1,2,-$ Dichloroethane

Total coliforns

Turbidity

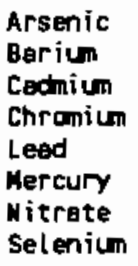

Endrin

Lindane

Methoxychlor

Toxaphene

$2,4,-D$

$2,4,5-\mathrm{TP}$

Aldicarb

Chlordane

Dalapon

Diquat

Endothal!

$2,3,7,8-T C D O$ (Dioxin)

Redium 226 and 228

Beta particle and photon

redioactivity viryl chloride

Hethylene

Benzene

Chlorobenzene

Dichlorobenzene

Microbiology and Turbidity

Giardie lanblis

viruses

\section{Inorganics}

Silver (a)
Flouride
Aluminum
Antianory
Molytodenm (a)
Ashestos
Sulfete
Copper

\section{Organics}

Glyphosate

Carbofuran

Alachlor

Epichlorchydrin

Tolvene

1,1,2-Trichloroethane

vydete

simazine

PAH's

PCB's

Atrazine

Hexach loroeycl opentadi ene

Radionucl ides

Uranium

Gross alpha particle activity

Radon
Trichlorobenzene

1,1-Dichloroethylene

trens-1,2, Dichloroethylene

cis-1,2,-Dichloroethylene

Standard plate camt Legionel le

Vanodiym(e)
Sodium(a)
Nickel
Zinc(a)
Thallium
Beryllium
Cyanide

Cyanide

(a) These have been removed from the list as of January 22, 1988 (53 FR 1892). Seven conteminamts edded to the list include: Aldricarb sulfone, Ethylbenzene, Heptachlorepoxide, Styrene, Aldricarb sulfoxide, Heptachlor and Nitrite. 
TABLE 5.2. Drinking Water Priority List (53 FR 1892, January 22, 1988)

Substance

$1,1,1,2$-Tetrachlorormane

$1,1,2,2$-Tetrachropethane

1,1-Dichloroethane

1,1-Dichloropropene

1,2,3-Trichloropropane

1,3-Dichloropropane

1,3-Dich1oropropene

2,2-Dichloropropane

$2,4,5-T$

2,4-Dinitrotoluene

Aluminum

Ammonia

Boron

Bromobenzene

Bromochloroacetonitrile

Bromodichl oromethane

Bromoform

Bromomethane

Chioramine

Chlorate

Chlorine

Chlorine dioxide

ChTorite

Chloroethane

Chioroform

Chloromethane

Chloropicrin

Cryptosporidium
Cyanazine

Cyanogen chioride

Dibromoacetonitrile

Dibromochloromethane

Dibromomethane

Dicamba

Dichloroacetonitrile

ETU

Hypochlorite ion

I sophorone

Methyl tert-buty 1 ether

Metolachlor

Metribuzin

Molybdenum

ozone byproducts

Silver

Sodium

Stront jum

Trichloroacetonitrile

Triflural in

Vanadium

Zinc

o-Chlorotoluene

p-Chiorotoluene

Halogenated acids, alcohols, a) dehydes, ketones, and other nitriles 
TABLE 5.3. Current and Proposed Standards for Bacteria: MCLs, MCLGs, Corrective Action

Parameter - Maximm Contaminant Level
Coliform
[WAC $248-54-175(3)]$
1. Membrane filter test, the number of
coliform shall not exceed:
a. 1 per $100 \mathrm{ml}$ as average of all
semples tested each month.
b. 4 per $100 \mathrm{ml}$ in 2 or more
semples when less than 20
samples are tested monthly
c. 4 per $100 \mathrm{ml}$ in more than $5 \%$
of samples when 20 or more
samples are tested each month.

Maximum

Contami nant

Level Goel.

samples are tested each morth.

2. MNP (most probable number of coliform bacteria per $100 \mathrm{ml}$ ) 5 tube method; coliform bacteria shall not be present in:

a. more then $10 x$ of the tubes tested each month

b. three or more tubes in 2 or more samples when less than
20 samples are tested each month

c. three or more tubes in more then $5 \%$ of the samples when 20 or more samples are tested each month.

3. Systems required allawed to take less than 4 samples each month may be allowed to base compliance with this section on the samples taken during the 3-month period consisting of the month in question and the previous two months.
Follow-up Action of Conteminent Levels Exceeded [WAC 24B-54-185(2)]

1. When any coliform bacteria is present in any semple analyzed by menbrane filter method the purveyor must take action as follows:

a. If sample results in 1 to 4 per $100 \mathrm{ml}$, sample is unsatisfactory and an extra sample must be taken to verify contamination.

b. If semple results in greater than 4 per $100 \mathrm{ml}$, the sample is unsat isfactory and nonconforming. Action must be taken to correct contemination and dily check samples shall continue until 2 consecutive samples show less than 1 per $100 \mathrm{mt}$ coliform.

2. When ary coliform bacteria is present in amy sample enolyzed by 5-tube MAP method the purveyor shall:

a. If sample results in one or two tubes positive, the semple is unsatisfactory. Collect an additional drinking water sample to confirm presence of contamination.

b. If three or more tubes are positive, the sanple is ursatisfactory and nonconforming. The purveyor shatl take action to determine and correct cause of contemination, collect deily check semples until two consecutive samples show no coliform present.

3. Additional samples must be collected from seme locetion that unsat isfactory semple was token.
Notification

[WAC 24B-54-185(2)]

1. Purveyor required to not ify DSHS within 48 hours once presence of coliform in water has been confirmed.

2. If primary MCL has been exceeded, purveyor must be notify systern users in accordance with WAC 248 -. $54-255$. 
TABLE 5.3. (contd)

\begin{tabular}{|c|c|c|c|c|c|}
\hline Parameter & & Maximm Contaminant Level & $\begin{array}{l}\text { Maximum } \\
\text { Contaminant } \\
\text { Level gool }\end{array}$ & & $\begin{array}{c}\text { Follow-up Action of } \\
\text { Contaminant Levels Exceeded }\end{array}$ \\
\hline \multirow[t]{5}{*}{ Coliform } & TWAC & $248-54-175(3)]$ & & IWAC & $248-54-185(2)]$ \\
\hline & 4. & $\begin{array}{l}\text { Special purpose samples, such as } \\
\text { those taken to determine if disin- } \\
\text { fection following pipe repair or } \\
\text { replacement has been sutficient (or } \\
\text { check samples), shall not be used } \\
\text { to determine compliance with the } \\
\text { maximum contaminant level. }\end{array}$ & - & 4. & $\begin{array}{l}\text { Additional sonples should be sub- } \\
\text { mitted for analyses as soon as pos- } \\
\text { sible after unsatiafactory results } \\
\text { are known. }\end{array}$ \\
\hline & 5. & $\begin{array}{l}\text { Sanples with unsuitable test } \\
\text { resul ts such os confluent grouth or } \\
\text { excess debris will neither qualify } \\
\text { as rout ine samples nor fulfill } \\
\text { monitoring requirements. }\end{array}$ & -. & 5. & $\begin{array}{l}\text { If the semple result is unsui table, } \\
\text { an odditional sanple sholl be inme- } \\
\text { diately submitted for anglysis. The } \\
\text { adyitional somple shall be enalyzed } \\
\text { by mpM method. }\end{array}$ \\
\hline & 6. & $\begin{array}{l}\text { The federal MCLs for Coliform at } \\
40 \text { CFR } 141.14 \text { are similar to the } \\
\text { state MCLs that are given above. }\end{array}$ & -. & 6. & $\begin{array}{l}\text { The location of the doily check sam- } \\
\text { ples shall not be eliminated from } \\
\text { future sempling without DSHS } \\
\text { approval. }\end{array}$ \\
\hline & & & & 7. & $\begin{array}{l}\text { The federal follow-Lo requirements } \\
\text { at } 40 \text { CFR } 141.21 \text { are similar to } \\
\text { those of the state (given obove). }\end{array}$ \\
\hline
\end{tabular}

Coliform 1. (52 FR 42224 - proposed rule) MCLS discussed at section 5.13 of text. 
IABLE 5.4. Standards for Bacteria: Monitoring

\begin{tabular}{|c|c|c|c|c|}
\hline \multicolumn{3}{|c|}{$\begin{array}{l}\text { Class } 1 \text { and } 2 \text { Systems } \\
\text { (WAC 248-54-165) (a) }\end{array}$} & \multicolumn{2}{|c|}{$\begin{array}{l}\text { Class III (Transitory Populations) } \\
\text { (WAC 248-54-165) }\end{array}$} \\
\hline $\begin{array}{l}\text { Number of } \\
\text { Permanent } \\
\text { Services } \\
\end{array}$ & $\begin{array}{c}\text { Permanent } \\
\text { Population }(a) \\
\text { Served } \\
\end{array}$ & $\begin{array}{l}\text { Minimum Number of } \\
\text { Samples_per Month }\end{array}$ & $\begin{array}{l}\text { Maximum Day } \\
\text { Population Served } \\
\text { in Any One Month } \\
\end{array}$ & $\begin{array}{l}\text { Minimum Number of } \\
\text { Samples that Month }\end{array}$ \\
\hline $\begin{array}{c}2-9 \\
10-99 \\
100 \text { or more }\end{array}$ & $\begin{array}{c}- \\
<1,001 \\
1,001-2,500 \\
2,501-3,300 \\
3,301-4,100 \\
4,101-4,900 \\
4,901-5,800 \\
5,801-6,700 \\
6,701-7,600 \\
7,601-8,500 \\
8,501-9,400 \\
9,401-10,300 \\
10,301-11,100 \\
11,101-12,000 \\
12,001-12,900 \\
12,901-13,700 \\
13,701-14,600 \\
14,601-15,500 \\
15,501-16,300 \\
16,301-17,200 \\
17,201-18,100 \\
18,101-18,900 \\
18,901-19,800 \\
19,801-20,700 \\
>20,700\end{array}$ & $\begin{array}{c}1 \text { every } 12 \text { months } \\
1 \text { (b) } \\
1 \\
2 \\
3 \\
4 \\
5 \\
6 \\
7 \\
8 \\
9 \\
10 \\
11 \\
12 \\
13 \\
14 \\
15 \\
16 \\
17 \\
18 \\
19 \\
20 \\
21 \\
22 \\
23 \\
\text { Refer to Table } 1 \\
\text { at WAC } 248-54-165\end{array}$ & $\begin{array}{rr}<25 & \\
25- & 299 \\
300- & 999 \\
1,000- & 2,499 \\
2,500-3,499 \\
3,500-4,999 \\
5,000-9,999 \\
10,000-14,999 \\
15,000-19,999 \\
>19,999 \\
\\
{[40 \text { CFR 141.21(c)] }} \\
\text { non-community-- } \\
\text { transitory }\end{array}$ & $\begin{array}{c}1 \text { every } 12 \text { months } \\
1 \text { every } 3 \text { months } \\
1 \\
2 \\
3 \\
4 \\
6 \\
8 \\
10 \\
\text { Refer to Table } 2 \\
\text { at WAC } 248-54-165\end{array}$ \\
\hline
\end{tabular}

(a) Federal monitoring requirements at 40 CFR 141.21 for Coliform are similar to those of the state (given above).

(b) May be reduced by DSHS to no less than one every three months for systems with protected groundwater sources. 
TABLE 5.5. Primary and Secondary Standards for Inorganic Chemical and Physical Contaminants

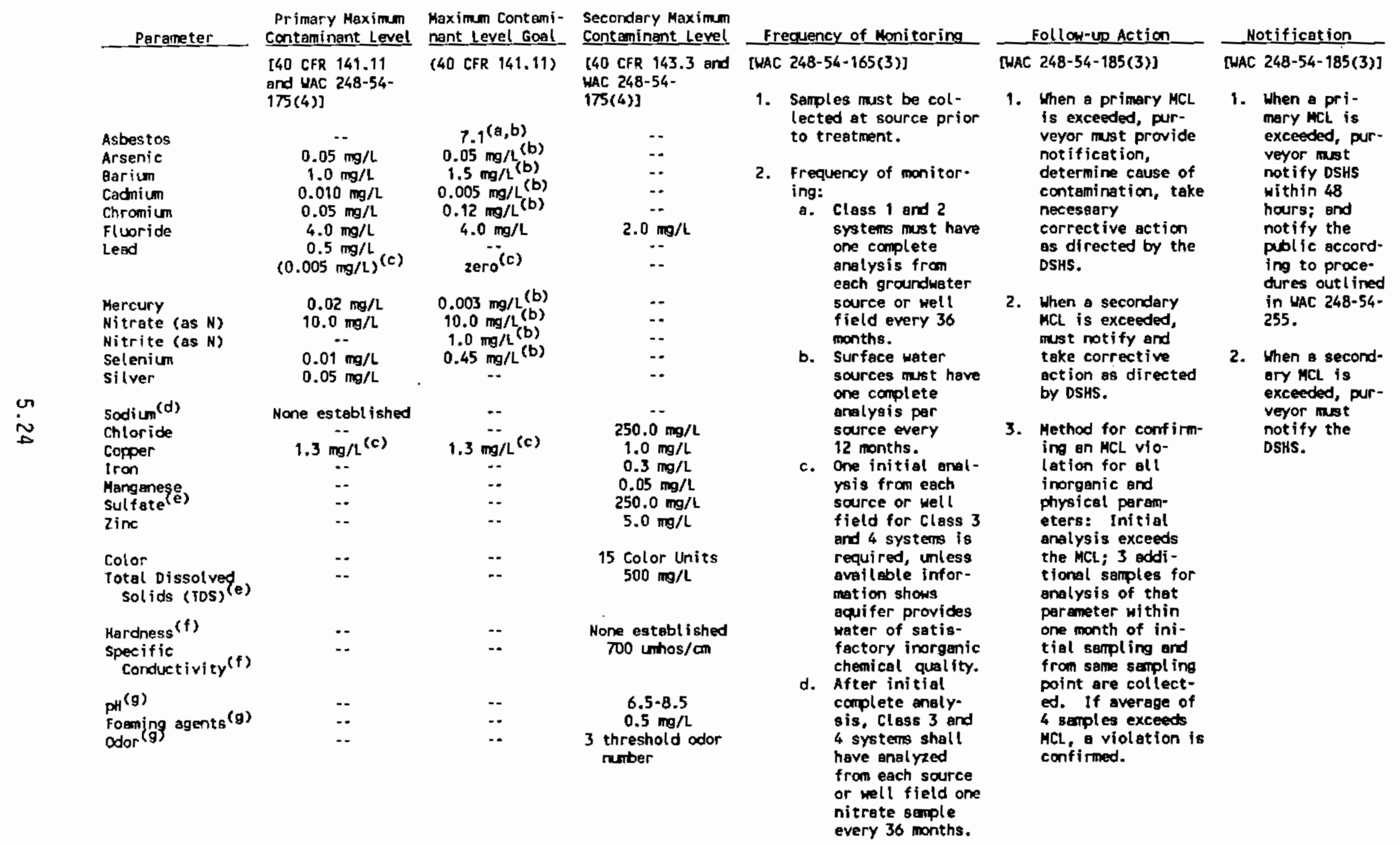


TABLE 5.5. (contd)

Primary Maxinum Maximm Contami- Secondary Maximum Parameter Contaminant Level rant Level Goal Conteminant Level

i

[WAC 248-54$175(4)]$

Turbidity
1 Turbidity Unit

(1 NTU) average

of the highest

two hourly read.

ings over a

26 hour period

when cont inuous

monitoring is

used, or average

taken within

1 hour when daily

monitoring is

used. The limit

may be inereased

to 5 NTUs if the

purvey can show

the source is a

controlled water

shed and meets

all the require-

54-125 and WAC

248-54-225.]
Frequency of Monitoring

e. If treatment is provided for one or more inorgenic or physical conteminant, semples shall be taken for the specific contaminant before and of ter fore and of ter frequency will be deternined by the DSHS.

[UAC 248-54-165(4)]

1. Turbidity manitoring

a. Class 1, 2, end 3 systems with sursystens with sources must sources must
moni tor turbidity at least once a day.

b. Turbidity mest be monitored ot or before the entry point to distripoint ion system and bution system and where needed for
process control.

c. Monitoring requi rements for Class 4 systens shall be deter mined by DSHS.
Follon-up Action

4. Method for confirm

ing an MCL viola-

tion for nitrate:

initial analysis

exceeds MCL/;

purveyor immedi-

ately col lects

ansther semple. If

overage of 2 sam

ples exceeds MCL, a

violation is

confi imed.

5. Purveyor must make

sodium analytical

resul ts avaitable

to publ ic upon

request.

[WAC 248-54-185(4)]

[NAC 248-54-185]

1. When turbidity exceeds maximm langer than 1 hour monitored continuonsly, purveyor mist notify DSHS wf thin 48 hours.

2. When reoults of menuel, turbidity onslysis exceeds maximm al lowebl I imit, another semple must be collected within 1 hour. When violation is con-

firmed, purveyor
1. Purveyor must notify DSHS notify
within 48 hours.
2. Purveyor must notify system users as out- lined at UAC- 248-54-255.


IABLE 5.5. (contd)

Primary Maxinum Maximm Contami- Secondary Meximum

Contaminant Level nent Level Goal Contaminant Level

$$
\begin{aligned}
& 5 \text { Turbidity Units } \\
& \text { based on average } \\
& \text { of the maximm } \\
& \text { daily turbidity } \\
& \text { for two consecu- } \\
& \text { tive days. }
\end{aligned}
$$

-

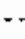

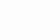

d.

d. Turbidimeters shall be properly

operated, main-

tained, and $\mathrm{cal}$

brated at all

times besed on

the manufactur-

tions.

(a) Million fibers per liter.

(b) Proposed federal regulations at 40 CFR 141.51 (50 ER 46936, Novenber 13, 1985).

(c) Proposed federal regulations at new subpert I of 40 CFR 141 (53 FR 31516, August 18, 1988 ).

(d) No maximum contaminant level has been promulgated for sodium; however EPA proposed en "optinal limit" of $20 \mathrm{mg} / \mathrm{L}$ in 1980 . Waghington requires thet sodium be monitored and results be mede available to doctors who treat persons on sadium-restricted diets [MAC-248-54-163(3)].

(e) Monitoring required for sulfate and total dissolved solids only when specific conductivity exceeds 700 micrombos/cent imeter (waC 248-54-165).

(f) Monitoring for these paraneters only required at state level (WAC 248-54-165). ollon-up Action

Within 48 hours,

cantamine couse of

take corrective

action as directed

by DSHS. (g) Monitoring for these perameters only required at federal level (40 CFR 143.3).

Notification 


\section{TABLE 5.6. Current Standards for Corrosivity}

Primary Maxinum Maxinum Contami- Secondary Maximum

Contaminant Level nant Level Goal Conteminant Level [WAC 248-54$175(6)]$

1. Follon-up action mest be taken if any corrosion byproduct ex ceeds the MCL or the increase in levels

between

source and

distribution

sampling

points is
significant.

2. Corrosivity character.

isties gen-

eralized by

Langlier

index:

Highly

aggressive $=$

$<-2.0$

Moderately

aggressive

$=-2.0$ to

0.0

Nonaggres-

sive $=>0.0$
(40 CFR 143.3)

Woncorrosive

[ [HAC 248-54-165(6)]

1. Cless 1 and 2 systerts surface water sources:

2 sets of 3 samples during a consecutive

12 month paríod, 1 set

during the winter, 1

in ing the winter,

water sources: 1 set per 12 month period, 1 sample in each set

must be taken prfor to

treatment and 2 semr

ples must be collected

from free flowing out-

from free flowing out

bution system at dif-

ferent points. Anely-

sis for corrosion

byproducts must

include cadnium,

copper, iron, lead,

zinc. Untreated

samples must also be

tested for alkal inity,

pH, hardness, temr

perature, TOS and

2. Classes 3 and 4 sys-

ters --DSHS will speci-

fy sempling frequency

if required.
Follow-us Action

Notification

1. When a comperison of the byproduct parameter shows an increese from sarce to distribution systen oction to be taken by purveyor as directed by DSHS.

2. Monitoring of corrosion characteristics of ter the initial sampling has been completed shall be as requi red by the DSHS. (HAC 248-54-165)
1. Purveyor notifies DSHS.

(a) Note the federal regutations include this on the list of secondary maximm contaminant levels, the stete of Weshington lists it in a category by itself.

(b) These changes reftected in state proposed draft regulations.

(c) Underlined portion deleted in proposed regulations. 
IABLE 5.7. Current Standards for Pesticides

\begin{tabular}{|c|c|c|c|}
\hline Parameter & \multirow{2}{*}{$\begin{array}{l}\text { Maximm } \\
\text { Contamínant Level } \\
\text { (40 CFR } 141.12 \\
\text { and WAC } 248-54- \\
\text { 175) }\end{array}$} & \multirow[t]{2}{*}{$\begin{array}{l}\text { Maximum Contami- } \\
\text { nant Level Gool }\end{array}$} & Monitoring \\
\hline & & & [WAC 248-54-165(7)] \\
\hline \multicolumn{3}{|l|}{ Pesticides } & \multirow{4}{*}{$\begin{array}{l}\text { Class } 1 \text { and } 2 \text { systems-- } \\
\text { once every } 36 \text { months. The } \\
\text { sample mot be collected } \\
\text { during the time of year } \\
\text { designated by oSHs or the } \\
\text { most likely time for } \\
\text { contamination to occur. } \\
\text { Additionel testing wili be } \\
\text { required as directed by } \\
\text { DSHS. }\end{array}$} \\
\hline $\begin{array}{l}\text { (i) Chlor inated } \\
\text { Hydrocarbons }\end{array}$ & & & \\
\hline $\begin{array}{l}\text { Endrin } \\
\text { Lindene } \\
\text { Mothoxychlor } \\
\text { Toxephene }\end{array}$ & \multirow[t]{2}{*}{$\begin{array}{c}0.0002 \mathrm{mg} / \mathrm{L} \\
0.004 \mathrm{mg} / \mathrm{L} \\
0.1 \mathrm{mg} / \mathrm{L} \\
0.005 \mathrm{mg} / \mathrm{L}\end{array}$} & \multirow[t]{2}{*}{$\begin{array}{c}0.0002^{(\theta)} \\
0.34^{(\theta)} \\
\text { zero }\end{array}$} & \\
\hline (ii) Chlorophenoxys & & & \\
\hline $\begin{array}{l}2,4-0 \\
2,4,5-\text { IP silvex }\end{array}$ & $\begin{array}{l}0.1 \mathrm{mg} / \mathrm{L} \\
0.01 \mathrm{mg} / \mathrm{L}\end{array}$ & $\begin{array}{l}0.07^{(a)} \\
0.052^{(a)}\end{array}$ & \\
\hline
\end{tabular}

$\frac{\text { Follow-Up Action }}{\text { (WAC 248-54-185) }}$

When MCL for a pesticide is exceeded, purveyor must notify the public (WAC 248$54-255$ ), determine cause of contanination, take neces. sary corrective action as directed by OSHS.
(WAC 248-54-185)

When MCL for pesticide is exceeded:

1. Purveyor must notify DSHS within 48 hars.

2. Purveyor must notify system users (WAC 248-54-185).

(a) Proposed federal regulations at $40 \mathrm{CFR} 141.50$ (b) (50 FR 46936, Novenber 13, 1985 ). 


\section{IABLE 5.8. Current Standards for Trihalomethanes}

Parameter

Total Trihalo-
Primary Maximum Maximm Contemi- Secondary Maximm
Contaminant Level nent Level Goal Contaminant Level

THAC 248-54.

$175(6)$ and $40 \mathrm{CFR}$

141.12]

methanes (TIHM)

\section{$0.10 \mathrm{mg} / \mathrm{L} \mathrm{ттнм}$}

The concentra-

tions of each of

trinalomethane

compounds I $t r i$ -

chloromethane

(chloroform)

dibromochloro-

methane, bramo-

dichloromethane,

(bromoform)] are

added together to

determine the

total trihalo-

methanes (ITHM)

tevel. of Moni toring [HAC. 248-54-165(5)]

Follow-up Action [UAC 248-54-185(5)]

Notification

1. For Class 1 groundwater systens serving 10,000 or more end

using chlorine or

other axidents;

1 untreated sample

well or mellfield

every 12 months must

be anelyzed for ITHM.

2. For Class 1 surface

weter systens serving

10,000 or more using

chlorine or other

oxidents: 4 every

3 months from each

treatment plant.

$1 f$ average of samples taken in 12-month period exceed MCL, and result

is confirmed with a check sample, system must monitor for at

least one year as followa: 4 samples from lows: 4 samples from
treatment plent of contaminated syster every 3 months must be col-

lected within a 24 -hour period, 25x of samples

taken from end of dis-

tribution aystem, $75 x$

from locetions repre-

sent ing population distribution.

3. Class 2, 3, and 4:

samples to be taken os recuired by DSHS.
1. Purveror no tifies DSHS within

48 hours.

2. Purveyor notifies oystem users. 


\section{TABLE 5.9. Current and Proposed Standards for Organic Chemicals}

\begin{tabular}{|c|c|c|}
\hline Parameter & $\begin{array}{c}\text { Maxinum } \\
\text { Contaminent Level }\end{array}$ & $\begin{array}{l}\text { Maximm Cont } \\
\text { nent Level } 6\end{array}$ \\
\hline $\begin{array}{l}\text { Volatile Organic } \\
\text { Chemicals }(a)\end{array}$ & $\begin{array}{l}\text { (52 FR } 25690 \\
\text { July } 8,1987)\end{array}$ & CFR \\
\hline $\begin{array}{l}\text { Benzene } \\
\text { vinyl Chloride } \\
\text { Carbon tetrachloride } \\
1,2 \text { Dichloroethane } \\
\text { Trichloroethane } \\
\text { 1,1-Dichloroethylene } \\
1,1,1-\text { Trichl oroethane } \\
\text { para-Dichlorobenzene }\end{array}$ & $\begin{array}{l}0.005 \mathrm{mg} / \mathrm{L} \\
0.002 \mathrm{mg} / \mathrm{L} \\
0.005 \mathrm{mg} / \mathrm{L} \\
0.005 \mathrm{mg} / \mathrm{L} \\
0.005 \mathrm{mg} / \mathrm{L} \\
0.007 \mathrm{mg} / \mathrm{L} \\
0.20 \mathrm{mg} / \mathrm{L} \\
0.075 \mathrm{mg} / \mathrm{L}\end{array}$ & $\begin{array}{c}0 \\
0 \\
0 \\
0 \\
0 \\
0.007 \mathrm{~m} \\
0.20 \mathrm{mg} \\
0.075 \mathrm{~m}\end{array}$ \\
\hline
\end{tabular}

\author{
Monitoring \\ [40 CFR $141.24(g)(1)(8)]$
}

$\frac{\text { Fol loy-lo Action }}{\text { [40 CFR } 141.24(9)(8)]}$

Groundwater systems must

for each entry point to the

distribution system except

distribution system except

as follows:

Schedule of Monitoring

Requirements

vocs are $(b)^{t}$

in the first

or any subse-

Repeat at

least every

cuent sample.

If MCLs for vocs exceeded:

If one location's average

(ruming annual average of curterly sempling) is

greater then MCL, system is out of complience unles

that pert of system is

seperable from rest of system.

System is immediately out of campl iance if only one

semple nould casse anedal

sverage to be exceeded.
Motification

40 CFR $141.24(g)(15)$

Public water system supplying <150 service connections shall be treated as complying with menitoring requiremente if omer or operator sencs a lette to the state that their system is available for sempling. No senple may be sent to the state un-

less 50 requested. This letter must be sent to state no later then Jenuery $1,1991$.

vocs are not

system is

vilnerable. (c)

Systems $>500$ Repeat every comections. 3 yeers.

Systems $<500$ Repeat every comections. 5 years.

Vocs detected Quarterly. in any sample.

[WAC $248-54-165(9,10)$ ]

As directed by the DSHS for To be determined by DSHS organic compounds with and hen MCL is exceeded. wi thout established MCls. 
IABLE 5.9. (contd)

Maximum Maximum Contami-

Contaminant Level nant Level Gool.

(Proposed fed-

eral reguletions

50 FR 46936 .

Novenber 13 .

1985)

\section{Organic Chemicals}

\section{Acrylamide}

Al achlor

Chlordane

DBCP

Epichlorohydrin

Heptachlor

Heptachlor epoxide

PCBs

Toxaphene

Aldicarb, Aldicarb sul-

foxide and Aldicarb

sulfone

Carbofuran

o-Dichlorobenzene

cis-1,2-Dichloroethylene

trans-1,2-Dich loro-

ethylene

1,2-Dichloropropene ${ }^{(d)}$

Ethylbenzene

Monoch Lorobenzene

Pentachlorophenol

Styrene

Toluene

Xylene

$\begin{array}{ll}-- & 0 \\ - & 0 \\ - & 0 \\ -- & 0 \\ -- & 0 \\ - & 0 \\ -- & 0 \\ - & 0 \\ -- & 0 \\ - & 0\end{array}$

Moni toring 
IABLE 5.9. (contd)

Maximu MaximLm Contami Parameter Contaminant Level nant Level Goal

Monitoring

(52 FR 25690, July 8, 1987) Follow-up Action 40 CFR 141.40(a): commnity water systems and nontrans ient, noncomminity water systens must monitor for unregulated orgenic chemicals listed at 40 CFR $141.48(e)$ by detes listed belor.

Bromodichl oromethane

Chlorodibromomethane

Bramoform

Irans-1,2-Dichloroethylene

o-Dichlorobenzene

Dibrancmethane

1,1-Dichloropropene

Tetrachl oroethylene

toluene

p-xylene

o-xylene

m-xylene

1,1-Dichloroethane

1,2-Dichloropropane

1,1,2,2-Tetrachl oroethane

Ethylbenzene

1,3-Dichloropropene

Styrene

Chlorome thane

Bromanethane

1,2,3- тrichloropropane

1,1,1,2-Tetrechloroethane

chloroethane

1,1.2-Tricht oroe thane

2,2-Dichloropropane

o-Ch larotoluene

p-chlorotoluene

Bromoberizene

1,3-Dichloropropene

\begin{tabular}{|c|c|}
\hline $\begin{array}{l}\text { Nunber of } \\
\text { Persons } \\
\text { Served }\end{array}$ & $\begin{array}{l}\text { Monitoring } \\
\text { to Begin mo } \\
\text { Later than }\end{array}$ \\
\hline $\begin{array}{l}10,000 \\
3,300 \text { to } \\
10,000 \\
\times 3,300\end{array}$ & $\begin{array}{l}\text { ก. 1, } \\
\text { ก. 1, }\end{array}$ \\
\hline
\end{tabular}

40 CFR 141.40(k): Fever

then 150 service connec-

tions requires only a let-

ter be sent stating system

is available for sampling

in tieu of performing moni -

toring.

40 CFR 141.40(1): Required monitoring mat be repeated at least once every

5 years.

40 CFR 141.40(i): AnY monitoring data collected any time ofter Januery 1 , 1983, to meet requirements

for unregulated moni toring

may be used by public water systems, provided the monitoring program wes

cons is tent with require

ments of this section

(40 CFR 141.40).
Not if ication

(FR 25690, July 8, 1987)

40 CFR 141.35: Send copy of monitoring resul ts within 3 days of receipt

to the state. The commnity or nontransient, noncommity water system must furnish the following information to the state or EPA (if the state has not adopted regulations

equivalent to $40 \mathrm{CFR}$

141.40):

a. Results of ell enslytical methods, including negotives.

b. Neme and address of the system that supplied the sample.

c. Conteminent(s).

d. Anolytical method(s) used.

e. Date of sample.

f. Date of enalysis. 
IABLE 5.9. (contd)

Meximem Maximum ContamiParameter

Ethylene dibromide (EDB)

1,2-dibromo-3-

chloropropane (DOCP)

\section{Regulated Organic Chemicals: State 141,401ji)}

1,2,4-Trimethylbenzene i,2,4-Trichloromenzene $1,2,3$-Trichlorobenzene n-Propyl benzene n-Butylbenzene Naph thal ene

Hexach lorobutadiene

1,3,5-Tr imethyl benzene

p-1sopropyl toluene

Isopropylbenzene

Tert-butylbenzene

Sec-butylberzene

Fluorotrichl oromethane

Dich lorodi f luoromethene

Bromochloromethane
Monitoring

(52 FR 25690, July B, 1987)
40 CFR 141.40(f): Commu-

nity water systems and

nont rans ient noncormunity water systems must monitor for EDB and ODCP only if state determines they are vulnerable to contemination by either or both of these gubstances. A groundwater system is witnerable in

areas there the componds

are ing ine compounds ere applied, manufactured. shipped in the groundwater recharge besin, or for groundwater systens that are located near underground storege tenks that contein leaded gesol ine.

(52 FR 25690, July 8, 1987)

Monitoring for these chemicals is required at the discretion of the state.
Fol Low-LP Action Motification

(a) The state of Washington has not promulgated regulations for volatile organic chemicals.

(b) Detected is $0.0005 \mathrm{mg} / \mathrm{L}$.

(c) Vulnerability determined by state.

(d) 1-2 Dichloropropane added to this tist in a proposed rule correction (51 FR 4618, February 2, 1986 ). 


\section{TABLE 5.10. Current and Proposed Standards for Radionuclides}

Parameter Level (State) (WAC 248-54-175) (40 CFR 141.15)

\section{[WAC 248-54-165(8)]}

Monitoring

Class I and II systems must monitor anc every 48 months or as directed by DSHS.

Naturally Occurring

$$
\begin{aligned}
& \text { Radium-226 } \\
& \text { Combined Radium-226 } \\
& \text { and Radium-228 } \\
& \text { Gross alphe perticle } \\
& \text { activity }
\end{aligned}
$$

\begin{tabular}{|c|c|}
\hline $\begin{array}{l}3 \mathrm{pCi} / \mathrm{L} \\
5 \mathrm{pCi} / \mathrm{L}\end{array}$ & $5 \mathrm{pCi} / \mathrm{L}$ \\
\hline $\begin{array}{l}15 \mathrm{pC} i / \mathrm{L} \\
\text { (excluding uranium) }\end{array}$ & $\begin{array}{l}15 \mathrm{pCi} / \mathrm{L} \\
\text { (including radium- } \\
226 \text {, but excluding } \\
\text { radon and uranium.) }\end{array}$ \\
\hline
\end{tabular}

\section{Manmade Radioactivity}

The maximu conteminant level for bete particle and photon radioactivity from manmade radionuclides is: the average annual concentration shall not produce an annual dose equivelent to the total body or any internal organ greater then $4 \mathrm{milli}$ rem/year. Compliance with the $4 \mathrm{millirem} /$ year dose limitation may be assumed if the amulal average concentration for gross bets activity, tritium, and strontium-90 are less than $50 \mathrm{pCi} / \mathrm{L}, 20,000 \mathrm{pCi} / \mathrm{L}$, and $8 \mathrm{pCi} / \mathrm{L}$, respectively, provided that if redionucl ides are present, the sum of their annual dose equivatents to bone marrow shall not exceed $4 \mathrm{mill}$ irem/year.

Compliance shall be based upon the 4 consecut ive quarterly samples or the average of the analysis of 4 samples obtained at quarterly intervals.

If gross alpha perticle ectivity is less than $5 \mathrm{PCi} / \mathrm{L}$, then no englysis for radium-226 and redium-22B is required. If results of initiol anolysis are less than half of establ ished MCL then compl iance wi th monitoring requfrenents may be based on single sample collected every 48 months.

For Class 1 systens using surface water sources and serving more then 100,000 persons and other moter systens $\Delta 8$ required by the DSHS, monitoring is required every 48 months. Monitoring once every 3 months for oross bets and 1- 131 . and once every 12 months for 5R-90 and $h-3$ is required for water systems domstreem from muclear facility.
Conpl iance

(WAC 248-54-185)

1. When MCL exceeded, purveyor must not ify DSHS within 48 hours ond not ify system users.

2. Purveyor must determine cause of contamination and take corrective action.

1. When MCL exceeded, purveyor must notify the DSHS and notify the system users.

2. Purveyor must determine the cause of contemination and take corrective action. 


\subsection{FEDERAL AND STATE CLEAN WATER ACTS}

Comparing surface water standards with groundwater quality standards may provide a better overall picture of current water standards and may be indicative of new standards considered for groundwater in the future. Thus, the following federal and state water pollution control laws are reviewed in this chapter: the Federal Water Pollution Control Act [Clean Water Act (CWA)], as amended; the State of Washington Water Pollution Control Act (RCW 90.48); and the state's implementing regulations (WAC 173-201, -216, and -220).

\subsection{FEDERAL CLEAN WATER ACT}

The objective of the CWA is to resolve and maintain the chemical, physical, and biological integrity of the nation's waters. To achieve these objectives, the CWA contains provisions for

- the development of effluent limitations and water quality standards (Title III)

- the implementation of such limits and standards through a National Pollutant Discharge Elimination System (NPDES) administered by EPA or states with authorized programs (Title IV)

- the regulation of $0 i 1$ and hazardous substances

- the use of dredge and fill material

- grants for construction of treatment works

- research for programs for the control of nonpoint sources of pollution (recently provided for in the 1987 Amendments to the (WA).

The CWA provides for the development of effluent limitations and water quality standards for use in the NPDES permit program. This program is applicable to point source discharges to navigable waters of the United States and covers surface waters only. NPDES permit program standards include biological oxygen demand, chemical oxygen demand, total organic carbon (TOC), total suspended solids (TSS), ammonia, temperature and pH; 
these standards are set forth at 40 CFR 122 and 124 . Several of these standards, such as TOC, TSP, temperature, and $\mathrm{pH}$, should be considered during the development of a groundwater protection program.

The federal standards for pollutants discharged to navigable waters are set forth at 40 CFR 117 and 40 CFR 129 . These standards may not be very useful or relevant to the development of a Hanford Site groundwater protection program. A 1 ist of hazardous substances and their associated reportable quantities is provided at 40 CFR 117.3. The substances on this list may indicate those constituents that may be of importance to the regulators; however, the use of reportable quantities for groundwater monitoring activities is not practical. A brief list of toxic pollutants, such as Aldrin/Dieldrin, DDT, Endrin, Toxaphene, Benzidine, and polychlorinated biphenyls (PCBs), is provided at 40 CFR 129.4. While more useful to the development of a groundwater protection program, it is unlikely that these toxic pollutants (excluding PCBS) will be detected in the Hanford Site groundwaters.

Recent amendments to the CWA, such as the requirement for the establishment of nonpoint source management programs by the states, may indicate that future regulations promulgated by EPA under the CWA will address groundwater pollution.

\subsection{WASHINGTON WATER POLLUTION CONTROL ACT, RCW 90.48}

The Washington Water Pollution Control Act applies to "waters of the state" which, unlike the federal definition of "waters of the United States," includes both surface waters and groundwaters. A state waste discharge permit is required under $\mathrm{RCW} 90.48 .160$ and WAC 173-216 for any discharge of pollutants into waters of the state. Two exceptions are point source discharges permitted under the NPDES program (WAC 173-220) and the injection of fluids through wells, which is permitted under the underground injection control program (WAC 173-218). However, the federal CWA's waiver of sovereign immunity (33 USC 1323) does not extend to state laws relating to control of groundwater pollution.

While not applicable to federal facilities, the state water quality standards (WAC 173-201) are briefly reviewed here. 
Regulations set forth in WAC 173-201-035(5) indicate that there are currently no standards for nonpoint source discharges. In accordance with 40 CFR $130.6(\mathrm{c})(4)$, the state is presently preparing a groundwater management plan that may establish standards for nonpoint source discharges to waters of the state. The state surface water quality standards, in general, apply to the various classes of surface waters in the state of Washington (WAC 173-201-045). The water quality criteria, such as fecal coliforms, dissolved oxygen, total dissolved gas, temperature, $\mathrm{pH}$, and turbidity, are assigned values based on the class of surface water. It may be useful to include some of these criteria (i.e., $\mathrm{pH}$, temperature, etc.) in developing a groundwater protection plan. 



\subsection{OTHER STATE OF WASHINGTON SIATUTES AND REGULATIONS RELEVANT TO GROUNDWATER}

Other Washington statutes and regulations which govern the use of groundwater are summarized in this chapter. Although DOE activities are not subject to these laws because their sovereign immunity has not been waived in these areas, consideration of concerns addressed by these laws is important because they are based on the common goal of environmental and public health protection. The statutes and implementing regulations that relate to discharges of wastes to groundwater, groundwater appropriations, groundwater management programs, and water well construction are summarized below. In particular, reporting, monitoring, and testing regulations and any prescribed standards are included in this chapter.

\subsection{POLLUTION DISCLOSURE ACT OF 1971}

Any commercial or industrial operation that discharges to the waters of the state is required by the Washington Pollution Oisclosure Act of 1971 (RCW 90.52) to develop a critical materials registry and to implement an annual reporting process.

The critical materials registry includes the following materials (WAC 173-40):

$\begin{array}{ll}\text { asbestos } & \text { cyanides } \\ \text { arsenic } & \text { fluorine } \\ \text { barium } & \text { lead } \\ \text { beryllium } & \text { mercury } \\ \text { boron } & \text { nickel } \\ \text { cadmium } & \text { organic phosphorus } \\ \text { chlorinated hydrocarbons } & \text { phenols and polychiorinated biphenyls } \\ \text { chlorine } & \text { selenium } \\ \text { chromium } & \text { silver } \\ \text { copper } & \text { zinc }\end{array}$


According to WAC 173-40-050, upon notification by the Director of WDOE, commercial and industrial operations that discharge wastes into waters of the state are required to file reports each January. The reports must include an estimate of the amounts of critical materials discharged from a process in the calendar year, if the quantities discharged exceed the amount of the quantities of critical materials in the feedstock of the process. The report must also indicate the volume of process and cooling water discharged into the water.

\subsection{REGULATION OF PUBLIC GROUNDWATERS}

The purpose of RCW 90.44, "Regulation of Public Groundwaters," is to regulate the appropriation and beneficial use of groundwaters within the state. Sections 90.44 .050 through 0.130 discuss the state permitting program for groundwater appropriation. The groundwater permit program extends the application of the surface water statutes at RCW 90.03 to include groundwater. Under this statute, facilities that withdraw more than 5000 gallons/ day may need a permit, depending on the use to which the water is put.

Groundwater management program requirements are the second major thrust of RCW 90.44. The implementing regulations for the groundwater management areas and programs are set forth at WAC 173-100. These regulations prescribe the guidelines, criteria and procedures for designating groundwater management areas, subareas, or zones and set forth procedures for the development of groundwater management programs.

The implementing regulations for protecting the occurrence and availability of groundwater within the upper aquifer or upper aquifer zones where there are multiple aquifer systems are described in WAC 173-154. These regulations are applicable to all groundwater under state jurisdiction. However, the monitoring inspection and testing requirements set forth at WAC 173-154-050 and -060 are limited to holders of water rights permits.

\subsection{WATER WELL CONSTRUCTION ACT OF 1971}

The Washington Water Well Construction Act (WWCA) (RCW 18.104) sets forth construction, maintenance and sealing requirements specifically for 
wells intended to be used only for the location, diversion, artificial recharge or withdrawal of groundwater. The recently adopted [Apri] 5, 1988 Washington State Register (WSR) 88-04-071] amendments to the WWCA's implementing regulations (WAC 173-160) expand the definition of "water well" construction, maintenance and sealing regulations for all wells. Effective May 5,1988 , a new section particular to resource protection wells (i.e., observation, monitoring, piezometer, spill response, and cased geotechnical test boring wells) is included.

The WWCA and implementing regulations are not strictly applicable to federal facilities. However, to assure the protection of public health and safety, DOE-RL complies with WAC 173-160 and 172-162 for the construction, maintenance, and closure of monitoring wells on the Hanford Site. These technical standards should also be considered during the development of the Hanford Site groundwater protection program.

The water well construction regulations have been cited in Washington's rules and regulations for Public Water Supplies (WAC 248-54) to ensure that drinking water supply wells are constructed so that public health is protected. To meet the SDWA requirements for protecting a drinking water source, the statute and regulations are applicable to constructed wells that may have an impact on a current or potential source of drinking water.

\subsubsection{General Requirements}

Well contractors are required to complete and submit to WDOE a record on the construction or alteration of every well within 30 days after they complete work [WAC 173-303-160-050(1)]. The minimum information that the May 5, 1988, amendments require in resource protection well records is as follows:

- project name

- location of well to at least $1 / 4,1 / 4$ section or smallest legal subdivision

- intended use of well

- depth, diameter, general specifications of each well 
- the depth, thickness and character of each bed, stratum or formation penetrated by each well

- commercial specifications of all casing, also of each screen or perforated zone in casing

- tested capacity of each well in gallons/minute

- for each nonflowing well, the depth to static water level as measured below land surface and drawdown of water level at the end of well capacity test

- for each flowing we11, the shut-in pressure measured above the 1 and surface, or in pounds per square inch at the land surface

- additional information as required by WDOE.

A new section, WAC 173-160-055, requires all well contractors to notify WDOE at least 72 hours before starting work of their intent to construct, reconstruct or abandon a wel1. This notification (start card), submitted on forms provided by WDOE, must include the well owner's name, well location, proposed use, approximate start and completion dates, driller's name and license number, drilling company's name, and contractor's registration number. In exceptional instances, an emergency, or a public health emergency, the WDOE will allow verbal notification to the appropriate regional office, with a start card followup.

\subsubsection{Water Supply Well Requirements}

Water supply wells in general should be located in accordance with the well site and access requirements prescribed at WAC 173-160-205. Before constructing a public water supply well, the contractor must obtain site approval from the DSHS or the local health authority and must meet public water regulations regarding the zone of protection, well location, accessibility, and certain construction requirements (WAC 248-54).

Individual, domestic, irrigation, industrial and other wells must also be located in accordance with local and state health regulations. Wells should be located at least 100 feet from a sewer 1 ine, sewer or 
manure lagoon, pipeline, or a known or suspected source of contamination. Wells should not be located within 1000 feet of solid waste landfills [WAC 173-160-205(2)].

Regulations prescribed in WAC 173-160-365 require that all toois and drilling equipment be thoroughly disinfected with a chiorine compound prior to beginning well construction. Before being placed in service following completion of construction or repair, every new or reconditioned well must be cleaned of a 11 foreign materials (WAC 173-160-365). These regulations require that all pumping equipment, sand or gravel, and the well casing be disinfected for at least 30 minutes with a solution containing at least $50 \mathrm{ppm}$ of chlorine. Before the water can be used for drinking, enough chlorine compound must be added to standing well water to give a residual of $50 \mathrm{ppm}$ free chlorine. The chlorine compound should then be thoroughly mixed with the well water and should remain in the well for at least 24 hours. During the 24-hour disinfection period, the free chlorine residual must not drop below $10 \mathrm{ppm}$. The well must then be flushed to remove all traces of chlorine. If testing indicates a presence of coliform bacteria, the DSHS or the local health authority may require more stringent disinfection methods.

The regulations also require that the chlorine in the rinse be allowed to dissipate before discharging the water, since chlorine at certain concentrations is toxic. Furthermore, the water must be discharged in a safe manner, consistent with the intent of the Water Pollution Control Act, RCW 90.48 .

\subsubsection{Resource Protection Wel1 Requirements}

The resource protection well regulations establish general design and construction standards (WAC 173-160-500) as well as design and construction standards for protecting ground surface from contamination (WAC 173-160510); casing that is nonreactive with the subsurface environment (WAC 173160-520); cleaning of the drill rig and equipment in areas of potential contamination (WAC 173-160-530); we 11 screen, filter pack, and development for wells installed for water quality sampling (WAC 173-160-540); well seals (WAC 173-160-550); and the abandonment of resource protection wells (WAX $173 \quad 160-560)$. 
The regulations include two reporting requirements. First, a well construction plan must be submitted to and approved by WDOE before the well is constructed. The required information was noted earlier in Section 7.3.1. Second, well abandonment must be recorded and reported to the WDOE within 30 days of abandonment.

\subsubsection{Regulation and Licensing of Water We1l Contractors and Operators (WAC 173-162)}

A well construction operator's license is required for any person who is employed by a well contractor or is self-employed as a contractor operator for the control and supervision of well construction and the operation of wel] construction equipment. Licensing and examination requirements are prescribed in WAC $173-162-040,-050,-060$, and -100 .

\subsection{WASHINGTON HAZARDOUS WASTE CLEANUP ACT}

The intent of the Washington Hazardous Waste Cleanup Act (HWCA) (a) (RCW 70.105B) is to maintain a healthful environment through cleanup of state hazardous waste sites. The HWCA can be applicable to cleanup of federal facilities only if the federal facility is not listed on the NPL [CERCLA Section 120 (a)(4)]. The applicability of HWCA to the Hanford Site is contingent upon the final listing of the Site on the NPL. As previousiy noted, four areas of the Hanford Site $(100,200,300$, and 1100 Areas) have been proposed for NPL Tisting (53 FR 2398B; June 24, 1988). If these proposed areas are 1isted, standards established by the state may be used as ARARs for remedial or removal actions performed at Hanford under CERCLA.

This statute aTso gives WDOE the legislative authority to carry out all state programs authorized under CERCLA and RCRA [RCW 70.105B.030(b)]. This statute is the enabling state law for implementing the 1984 Hazardous and

(a) In Washington's November 1988 elections, voters passed an initiative requiring the legislature to re-examine this Act. During the next year, the legislature will decide whether to amend or repeal this Act. Until statutory changes are enacted, however, this law remains the legislative authority for state dangerous waste clean-up programs. 
Sol id Waste Amendments to RCRA. At the present time, HSWA corrective action authority has not yet been delegated to the state of Washington by EPA.

Section 3.0 of HWCA gives WDOE the power to conduct, provide for conducting, or require potentially liable persons to conduct remedial actions to remedy a release or threatened release of a hazardous substance [RCW 70.105B.030(a)]. The degree of remediation required for hazardous substance clean-up actions must, at a minimum, meet the substantive requirements of applicable state and federal laws, regulations and rules (RCW 105B.060). If there are no applicable standards for a particular hazardous substance, WDOE will evaluate the magnitude of contamination at a site on a case-by-case basis and will determine the level of cleanup necessary to protect human health and the environment. To verify the effectiveness of a remedial action, groundwater monitoring may be necessary. No prescriptive groundwater monitoring requirements are currentiy provided within HWCA; however, WDOE is developing draft implementing regulations. The WDOE is also developing regulations for site investigations, which may be of importance to a groundwater monitoring program. Guidance establishing definitions of clean-up standards, which will include a list of ARARs, will also be developed.

Since this legislation is new, the Washington State Register should be closely monitored as the implementing regulations are developed. Specifical1y, those regulations that deal with notification/reporting requirements and monitoring standards/requirements for groundwater activities should be tracked. 
$\therefore$ 


\subsection{DEPARTMENT_OF ENERGY_ORDERS}

The DOE orders provide guidance and establish standards and policies for DOE and DOE contractor operations. Existing and draft DOE Orders that may impact groundwater monitoring activities have been reviewed and are discussed in this chapter.

\subsection{EXISTING DEPARTMENT OF ENERGY ORDERS}

This section presents discussions of those orders that are currently in effect and being applied to DOE and DOE contractor operations.

\subsubsection{DOE-RL Order 4330.2 - Water Treatment Plants and Distribution Systems}

Requirements for the operation and maintenance of Hanford potable water treatment plants and their distribution/storage systems are discussed in DOERL Order 4330.2. Testing requirements for coliform, residual chlorine, and turbidity are included in this Order. Additionally, managers of the Hanford Site Potable Water Treatment $\mathrm{Pl}$ ant and Distribution System are responsible for operating and maintaining "assigned treatment plants in accordance with existing DOE and other Federal directives, and safe drinking water standards."

\subsubsection{DOE Order 5400.1 - General Environmental Protection Program, 11-9-88}

This Order, which cancelled Chapter XII of 5480.1A, establishes environmental protection program requirements for DOE operations to ensure compliance with applicable federal, state, and local environmental protection laws and regutations, Executive Orders, and DOE policies. This Order more specifically defines environmental protection requirements that are generally established in DOE 5480.18.

All five chapters of this order are relevant to a groundwater monitoring program. Chapter 1 lists laws, regulations and Executive Orders that contain mandatory environmental protection standards.

\section{Chapter II: Notification and Reports}

Chapter II establishes requirements for 1) notification and followup of environmental occurrences and 2) periodic routine reporting of significant 
environmental protection information. Section 4(c) requires that all DOE facilities prepare an annual site environmental report. The purpose of this report is to summarize environmental data, including groundwater monitoring data. Attachment II-I, Annual Site Environmental Reports, Paragraph (10) describes the groundwater program. The annual report should describe the monitoring program, including the number of wells, sampling method, sampling frequency, anaiyses performed, and a summary of results. There should a]so be a summary of the hydrogeology of the site, major aquifers, movement of groundwater, potential sources of groundwater pollution, and uses of groundwater in the vicinity of the site.

\section{Chapter III - Environmental Protection Program Plans}

This chapter estabijshes requirements for DOE Operations to deveTop and implement specific program plans for each facility or group of facilities. Under this Order, an implementation plan and a long-range environmental protection $\mathrm{plan}$ must be developed. In addition, a groundwater protection management program must inciude the following:

- documentation of the groundwater regime with respect to quantity and quality

- design and implementation of a groundwater monitoring program to support resource management and comply with applicable environmental laws and regulations

- a management program for groundwater protection and remediation, including specific SDWA, RCRA, and CERCLA actions

- a summary and identification of areas that may be contaminated with hazardous substances

- strategies for controlling sources of these contaminants

- a remedial action program that is part of the site CERCLA program

- decontamination and decommissioning

- other remedial programs.

Plans, permits, and other technical documents such as those associated with compliance with the SDWA, RCRA, and CERCLA may be used in whole or in part to 
satisfy this requirement. This plan is to be completed no later than 18 months after the effective date of the Order (November 11, 1988). The plan must be reviewed annually and updated every 3 years.

Chapter IV - Environmental Monitoring Requirements

This chapter contains requirements and guidance for environmental monitoring programs.

Preoperational Monitoring. An environmental study must be conducted before the startup of a new facility. The study must

- characterize existing physical, chemical, and biological conditions that could be affected

- establish background levels of radioactive and chemical components

- characterize pertinent environmental and ecologic parameters

- identify potential pathways for human exposure or environmental impact.

Groundwater monitoring data and information, such as that gained from the sitewide monitoring program, will be used during this study.

Environmenta] Monitoring Plans. A written environmental monitoring plan must be prepared for each site. The plan must contain

- the rationale and design criteria for the monitoring program

- the extent and frequency of monitoring and measurements

- procedures for laboratory analyses

- quality assurance requirements

- program implementation procedures

- direction for the preparation and disposition of reports.

The plan must identify and discuss two major activities: 1) effluent monitoring, and 2) environmental surveillance [Chapter IV(3)].

Effluent monitoring must be conducted to

- verify compliance with applicable regulations and Orders 
- determine compliance with comitments made in official documents such as EISs and EAs

- evaluate the effectiveness of effluent treatment and control

- identify potential environmental problems and evaluate the need for remedial actions

- support permit applications

- detect, characterize, and report unplanned releases [Chapter IV(5)(a)].

Environmental surveillance must be conducted to monitor the effects of DOE activities on onsite and offsite environmental and natural resources. Environmental surveillance must satisfy the following objectives:

- verify compliance with applicable regulations

- verify compliance with environmental commitments made in official DOE documents such as EISs, EAs, SARs

- characterize and define trends in the physical, chemical and biological condition of environmental media

- establish baselines of environmental quality

- provide a continuing assessment of pollution abatement programs

- identify and quantify new or existing environmental quality problems [Chapter IV(5)(b)].

Groundwater Monitoring Program. Groundwater that is or could be affected by DOE activities must be monitored to determine the effects of operations on groundwater quality and quantity and to demonstrate compliance with DOE requirements and applicable laws and regulations. Groundwater monitoring plans must identify these requirements, laws and regulations. Groundwater monitoring programs must be conducted to

- obtain data for determining baseline conditions of groundwater quality and quantity

- demonstrate compliance with and implementation of a17 applicable regulations and DOE Orders 
- provide data to permit the early detection of groundwater pollution or contamination

- provide a reporting mechanism for detected groundwater pollution or contamination

- identify existing and potential groundwater contamination sources and maintain surveillance of these sources

- provide data upon which decisions can be made concerning 1 and disposal practices and the management and protection of groundwater resources.

Site-specific characteristics will determine monitoring needs. Where appropriate, groundwater monitoring programs will be designed and implemented in accordance with the RCRA regulations at 40 CFR 264 or 265 . Groundwater monitoring programs for sites with multiple groundwater pollutant sources, extensive groundwater pollution or other unique site problems could require more extensive information than those specified in 40 CFR 264 and 265. Monitoring for radionuclides must be in accordance with DOE Orders $(5400$ series) [Chapter IV( 9$)(a-c)]$.

\subsubsection{DOE Order 5480.1A - Environmental Protection, Safety, and Health} Protection Program for DOE Operations, 8-13-81

This Order, which cancelled DOE Order $5480.1(5 / 5 / 80)$, contained 13 chapters which established DDE policies and requirements in various areas. These chapters have now been redesigned as separate Orders by DOE Order 5480.1B. However, until the new Orders are promulgated, the individual chapters of 5480.1A remain in effect, even though the Order itself $(5480.1 \mathrm{~A})$ has been cancelled.

The individual chapters of $5480.1 \mathrm{~A}$ relevant to a groundwater monitoring program, along with their draft replacement Orders (if they contain significant changes) are discussed in subsequent sections.

Chapter XI addresses radiation protection for occupational exposure to individuals and population groups within DOE controlled and uncontrolled areas. Attachment $l$ of this chapter contains concentration guides for various radionuclide isotopes in air and water. These concentration guides 
are used to evaluate the adequacy of health protection measures. Groundwater monitoring programs should consider including these guidelines.

\subsubsection{DOE Order 5480.1B - Environmental Protection Safety, and Health Program for DOE Operations, 9-23-86}

This Order, which cancelled DOE Order 5480.1A (8/13/81), describes the series of Orders that will replace DOE Order 5480.1A. The replacement order reTevant to a groundwater monitoring program is 5480.4 .

\subsubsection{DOE Order 5480.4 - Environmental Protection, Safety, and Health Protection Standards, 5-15-84 - as amended by DOE Order 5480.4, Chg 1, 5-16-88 (formeriy Chapter I of DOE Order 5480.1A, 8-13-81)}

This Order contains three attachments: Attachment 1, Mandatory Environment, Safety and Hea]th (ES\&H) Standards (Statutory Requirements); Attachment 2, Mandatory ES\&H Standards (Policy Requirements); and Attachment 3, Reference ES\&H Standards.

Attachment 1 lists statutes and regulations that contain ES\&H standards that are mandatory as a result of federal or state statutes and/or implement. ing requirements. Those important to a groundwater monitoring program include the CWA, the SDWA, and the RCRA.

\subsubsection{DOE Order 5484.1 - Environmenta] Protection, Safety, and Health Protection Information Reporting Requirements, 2-24-81, as amended by Chg 1, 6-9-81; Chg 2, 8-13-81; and Chg 3, 11-6-87}

The purpose of this Order is to establish requirements and procedures for reporting information that has environmental protection, safety, or health protection significance for DOE operations.

\section{Chapter I}

Chapter $I$ is divided into 3 sections: 1) immediate notification, 2) notification within 72 hours, and 3 ) information required in notification made immediately or within 72 hours. Reportabie occurrences that are of importance to a groundwater monitoring program are discussed below.

Immediate Notification. The Headquarters Emergency Operations Center must be notified as soon as sufficient information has been obtained to show 
the nature and extent of an occurrence. From the list of occurrences (a through $r$ ) that $f a l l$ under this requirement, only $e, f$, and $q$ are of interest to a groundwater monitoring program.

- "e. Any accidental releases of pollutants which result or could result in significant effect on the public or on the offsite environment, e.g., need to relocate people, substantial fish kill, requirements for corrective action in the environment, requests that downstream water supply intakes be shut down, etc."

- "f. Any accidental releases of pollutants designated by the Environmental Protection Agency as 'hazardous' and requiring activation by the Environmental Protection Agency or the U.S. Coast Guard of the National $0 i 1$ and Hazardous Substances Pollution Contingency $\mathrm{Plan}$ to effect removal or corrective measures."

- "q. Any discovery of significant radioactive or nonradioactive contamination in the onsite or offsite environment attributable to current or past Department of Energy operations."

Notification Within 72 Hours. Occurrences requiring notification (items a through i) are generally less severe than those under the immediate notification requirements. Two occurrences under this heading could potentially be relevant to groundwater monitoring activities:

- "e. Any radiation exposure to an individual which in 1 calendar quarter exceeds the following:

(1) $5 \mathrm{rem}$ to the whole body

(2) 15 rem to skin of whole body or thyroid

(3) $30 \mathrm{rem}$ to the forearms

(4) 75 rem to the hands or feet."

- " $f$. Any internal uptake of radioactive material which on the basis of a small number of early assay data could result in a dose or dose commitment in excess of the pertinent annual standard set forth in the order DOE 5480.1 Chapter XI, 'Standards for Radiation Protection.' For whole-body dose, 5 rem is the pertinent annual standard." 


\section{Information Reguired in Notification Made Immediately or Within}

72 Hours. This section contains no groundwater monitoring requirements; however, much of the information about a particular occurrence could come from groundwater monitoring data such as the nature of and consequences of an occurrence.

\section{Chapter II}

Chapter II, which addresses occurrence investigations, contains no groundwater monitoring requirements; however, the manager of a groundwater monitoring program could be called upon to provide either monitoring support to an investigation or monitoring data for different parts of the resulting report.

\section{Chapter III}

Chapter III (Effluent and Environmental Monitoring Program Requirements) describes DOE requirements for an environmental monitoring program for air, water, soil, and other media. These requirements are summarized below.

An environmental survey must be conducted before startup of a new site facility or process that has the potential to adversely affect the environment or that will process, release, or dispose of pollutants. The results of this survey will be used to establish background levels of radioactive and toxic pollutants, to characterize environmental parameters, and to determine pathways for human exposure or environmental impact. Groundwater monitoring information may be used as input to this survey.

Existing sites and sometimes former sites, as determined on a caseby-case basis, must be monitored for radioactivity. This is to determine whether releases are contained properly and whether the levels of radioactivity found comply with applicable standards, as well as the overall impact of DOE operations on the environment. This determination may be partially based on groundwater monitoring results.

The scope and content of an environmental monitoring program are described in this chapter, as well as the reports and summaries generated by the program. The overall scope of environmental monitoring program is to determine 
- compliance with the requirements of Order DOE 5480.1, Chapters I, $X I$, and $X I I$

- the background levels and site contribution of radioactivity and, as appropriate, other pollutants in the site environs

- compliance with applicable environmental quality and public exposure limits and other environmental commitments (e.g., those published in environmental impact statements or other official documents).

One of the primary purposes of the environmental monitoring program is to prepare the environmental report. The requirements of the environmental report are summarized below:

- An environmental monitoring report is to be prepared annually. The report should summarize and interpret the levels of radioactivity and, as appropriate, of nonradioactive pollutants that are in the environs of $D O E$ sites and that are attributable to site operations. Levels of pollutants should be placed in perspective by comparing them with applicable standards and with relevant parameters, such as background and natural radioactivity.

- The environmental monitoring report should summarize the results of monitoring to determine compliance with applicable effluent standards and permit conditions.

- In general, onsite monitoring data need not be included in the environmental monitoring report unless the data are necessary to demonstrate compliance with applicable standards or may be helpful in interpreting offsite data. Effluent monitoring data for poliutants must be included in the report, if needed to demonstrate whether or not such effluents are in compliance with applicable effluent, emission, or environmental standards or if used to calculate offsite impacts.

If it is not necessary to prepare an environmental report at a particular DOE site, then an abbreviated document, an environmental summary, must be prepared. 
The latter part of Chapter III includes monitoring guidelines for onsite discharges, monitoring locations, type and frequency of sampling, and monitoring data recordkeeping. Effluents must be monitored to determine compliance with ail effluent limits imposed by DOE, EPA and state agencies, etc. Finally, general guidance is provided for monitoring locations, type and frequency of samples, and data recordkeeping.

\section{Chapter IV}

Chapter IV inciudes dates for submitting environmental reports and sumnaries.

\subsubsection{DOE Order 5820.2A - Radioactive Waste Management, 9-26-88}

The purpose of this Order is to establish policies, guidelines, and minimum requirements by which DOE manages its radioactive and mixed waste and its contaminated facilities.

The waste management plan outline section requires that environmental monitoring programs describe the status of environmental monitoring that supports waste management operations; discuss monitoring installations, media sampled and constituents analyzed; and describe planned system upgrades and modifications.

The low-leve] waste management section (Chapter III) requires that each operational or non-operational low-level waste TSD facility be monitored by an environmental monitoring program that conforms with appropriate DOE orders and other requirements specified in this draft order. The groundwater monitoring called for is not primarily for reporting purposes, but rather to assist site selection decisions. Paragraph 3(a)(4) of this Chapter requires that groundwater resources be protected consistent with federal, state, and local requirements. Paragraph $3(i)(7)(c)$ requires that selection criteria for a low-level waste disposal site should address, as appropriate, "hydrogeologic characteristics which, in conjunction with the planned waste confinement technology, will protect the groundwater resource." Given these requirements, groundwater monitoring data are likely to be used for site seTection. 
Paragraph $3(i)(8)(a$ and $b$ ) requires that design criteria for a low-level waste disposal site be based on hydrogeological data. A groundwater monitoring program manager is likely to be consulted for this task.

Paragraph $3(1)(9)$ requires that an environmental monitoring program (including monitoring wells) be addressed when disposal site operating procedures are being developed and implemented. Again, it is likely that a groundwater monitoring program manager will be consulted.

Paragraph $3(k)$ discusses environmental monitoring including groundwater monitoring. The monitoring program must be capable of detecting changing trends to allow application of any necessary corrective action.

\subsection{PROPOSED DEPARTMENT OF ENERGY ORDERS}

This section contains a discussion of proposed DOE Orders that may affect groundwater monitoring activities for DOE and DOE contractor operations.

\subsubsection{Proposed DOE Order 5400.XX - Radiation Protection of the Public and the Environment}

This Order cancels Chapter XI of DOE Order 5480.1A. When issued, this Order witl become 5400.3.

The purpose of this Order is to establish standards and requirements for DOE's operations with respect to protecting the public and the environment against undue risk from radiation.

This Order establishes the framework for radiation protection, while the specific requirements for radiological effluent monitoring and environmental surveillance witl be detailed in Draft DOE Order 5400.xy.

Chapter III of DOE Order 5400.xx contains Derived Concentration Guides for ingested water. These may be used as standards in a groundwater monitoring program. 


\subsubsection{Proposed DOE Order 5400.xy - Radiological Effluent Monitoring and Environmental Surveill ance}

This draft Order will describe the requirements and provide guidance for monitoring effluents and conducting environmental surveillance.

\subsubsection{Proposed DOE Order 5480.12 - General Environmental Protection Program Requirements}

The purpose of this Order is to "provide comprehensive direction for programs designed to assure compliance with environmental regulations and DOE policies."

The following changes have been proposed:

- Transfer the environmental standards requirements from DOE 5480.4 to DOE 5480.12

- Transfer the environmental reporting requirements from DOE 5484.1 to DOE 5480.12.

If this Order becomes final, the above sections will be cancelled in their source Orders.

This Order is divided into 4 sections. The following is a brief summary of the portions of these sections that may impact groundwater monitoring.

Section I - Environmental Protection Standards

This section identifies mandatory standards that are either imposed by federal or state regulatory agencies or are self-imposed by DOE. No specific groundwater monitoring requirements are described here.

\section{Section II - Notification and Reporting}

Paragraph 2 within this section states, "Consistent with the notification requirements contained in Orders DOE 5484.1 and 5000.3, field organizations sha11 notify and report to the Assistant Secretary for Environment, Safety, and Health (EH-1), on the release of any pollutant or hazardous substance that is required to be reported by any environmental statute, regulation, or DOE Order." If groundwater monitoring activities result in a release, reporting will be required in accordance with this section. 


\section{Section III - Environmental Management Program Plan}

This section describes the Environmental Management Program Plan (EMPP) that must be developed and implemented by a Head of Field Organization for each facility or group of facilities for which the Head is responsible. Paragraph 2(b)(I) within this section requires the EMPP to have a Program Description and Documentation Section that includes an environmental monitoring program which considers

- effluent monitoring

- environmental surveillance

- meteorological information/monitoring

- groundwater monitoring

- quality assurance.

Section IV - Environmental Monitoring Program Requirements

This section contains general requirements for environmental monitoring programs to monitor air, soil, groundwater, and other important media for the presence of pollutants that could have adverse impacts on safety, health, and the environment.

Paragraph 7 of this section outlines a specific program for monitoring groundwater potentially affected by DOE activities. The general requirements of this paragraph are to

- obtain data to determine baseline conditions of groundwater quality and quantity

- demonstrate compliance with and implementation of all applicable regulations and DOE Orders

- provide data for the early detection of groundwater pollution or contamination

- identify existing and potential groundwater contamination sources and maintain surveillance of these sources

- provide data upon which decisions can be made concerning land disposal practices and the management of groundwater resources. 
These five requirements are to be accomplished by designing and implementing groundwater monitoring programs in accordance with 40 CFR Part 264, Subpart F, or 40 CFR Part 265, Subpart F. 


\section{REFERENCES}

Arbuckle, J. G. et al. 1987. Environmental Law Handbook. Government Institutes, Inc., 966 Hungerford Drive \#24, Rockville, Maryland.

Reeverts, C. 1987. "Toxics and Hazardous Waste and Law Management as Spelled out in the Clean Water Act and Safe Drinking Water Act." Paper presented at the Fourth Annual Hazardous Waste Law and Management Conference, December 10-11, 1987, Seatt7e. Sponsored by the U.S. Environmental Protection Agency (Region 10) and the University of Washington School of Law.

Somers, S. R. 1986. Hanford Sanitary Water Quality Surveillance. HEHF-55, Hanford Environmental Hea7th Foundation, Richland, Washington 99352.

U.S. Environmental Protection Agency. 1986. Guidelines for Groundwater Classification under the EPA Groundwater Protection Strategy. U.S. Environmental Protection Agency, Office of Groundwater Protection, Washington, D.C. 20460 .

U.S. Environmental Protection Agency. 1987. Guidelines for Delineation of Welihead Protection Areas. U.S. Environmental Protection Agency, Office of Groundwater Protection, Washington, D.C. 20460. 
. 
PNL-6826

UC -630

\section{DISTRIBUTION}

No. of

Copies

OFFSITE

10 DOE/Office of Scientific and Technical Information

\section{ONSITE}

11 DOE Richland Operations Office

M. J. Anthony

E. A. Bracken

G. J, Bracken

J. J. Broderick

R. M. Carosino

R. D. Freeberg

R. E. Gerton

R. A. Holten

A. J. Knepp

E. C. Norman

M. W. Tiernan

12 Westinghouse Hanford Company
M. R. Adams
L. C. Brown
G. D. Carpenter
C. Defigh-Price
K. R. Fecht
K. A. Gasper
R. E. Lerch
H. E. McGuire
L. L. Powers
S. A. Wiegman
R. D. Wojtasek
D. D. Woodrich

No. of

Copies

57 Pacific Northwest Laboratory

R. C. Adams

S. P. Airhart

W. J. Bjorklund

B. N. Bjornstad

T. M. Brouns

R. W. Bryce

M. A. Chamness

D. R. Dah1

J. F. Falco

C. A. Geffen

R. E. Gephart

T. J. GiTmore

S. M. Goodwin

R. H. Gray

S. H. Hall

M. S. Hanson

E. J. Jensen

B. J. Kaiser

J. F. Keller (20)

G. V. Last

R. E. Lundgren

S. P. Luttrell

P. J. Mitchel1

I. C. Nelson

R. Schalla

A. J. Schmidt

K. B. Selby

R. L. Skaggs

R. M. Smith

S. L. Stein

S. S. Tee]

E. J. Westergard Publishing Coordination Technical Report Files (5) 
.

$\because$ 